Daniel Gersten Reiss

Ensaios sobre a Internacionalização da Moeda

Brasília 
Daniel Gersten Reiss

\title{
Ensaios sobre a Internacionalização da Moeda
}

Tese de conclusão de curso apresentada como requisito para a obtenção do grau de Doutor em Economia na Universidade de Brasília.

\author{
Universidade de Brasília - UnB \\ Faculdade de Economia, Administração e Contabilidade \\ Programa de Pós-Graduação em Economia
}

Orientador: Maurício Barata de Paula Pinto

Brasília

2015 
Ficha catalográfica elaborada automaticamente, com os dados fornecidos pelo(a) autor(a)

Reiss, Daniel Gersten

Ensaios sobre a Internacionalização da Moeda Daniel Gersten Reiss; orientador Maurício Barata de Paula Pinto. -- Brasília, 2015.

$132 \mathrm{p}$.

Tese (Doutorado - Doutorado em Economia) -Universidade de Brasilia, 2015.

1. Moeda internacional. 2. Uso da Moeda. 3. Distribuição de renda. 4. Real (moeda do Brasil). I. de Paula Pinto, Maurício Barata, orient. II. Título. 
RELATÓRIO DE DEFESA DE TESE

Universidade de Brasília - UnB

D O U T O RA D O

Decanato de Pesquisa e Pós-Graduação - DPP

Secretaria de Administração Acadêmica - SAA

1 - Identificação do Aluno

Nome

Matrícula

Daniel Gersten Reiss

Curso

Economia

\begin{tabular}{|l|l|l}
\hline Área de Concentração & $\begin{array}{l}\text { Código } \\
3743\end{array}$ & $\begin{array}{l}\text { Departamento } \\
\text { ECO }\end{array}$ \\
\hline
\end{tabular}

\section{2 - Sessão de Defesa de Tese}

Título

Ensaios sobre a Internacionalização da Moeda.

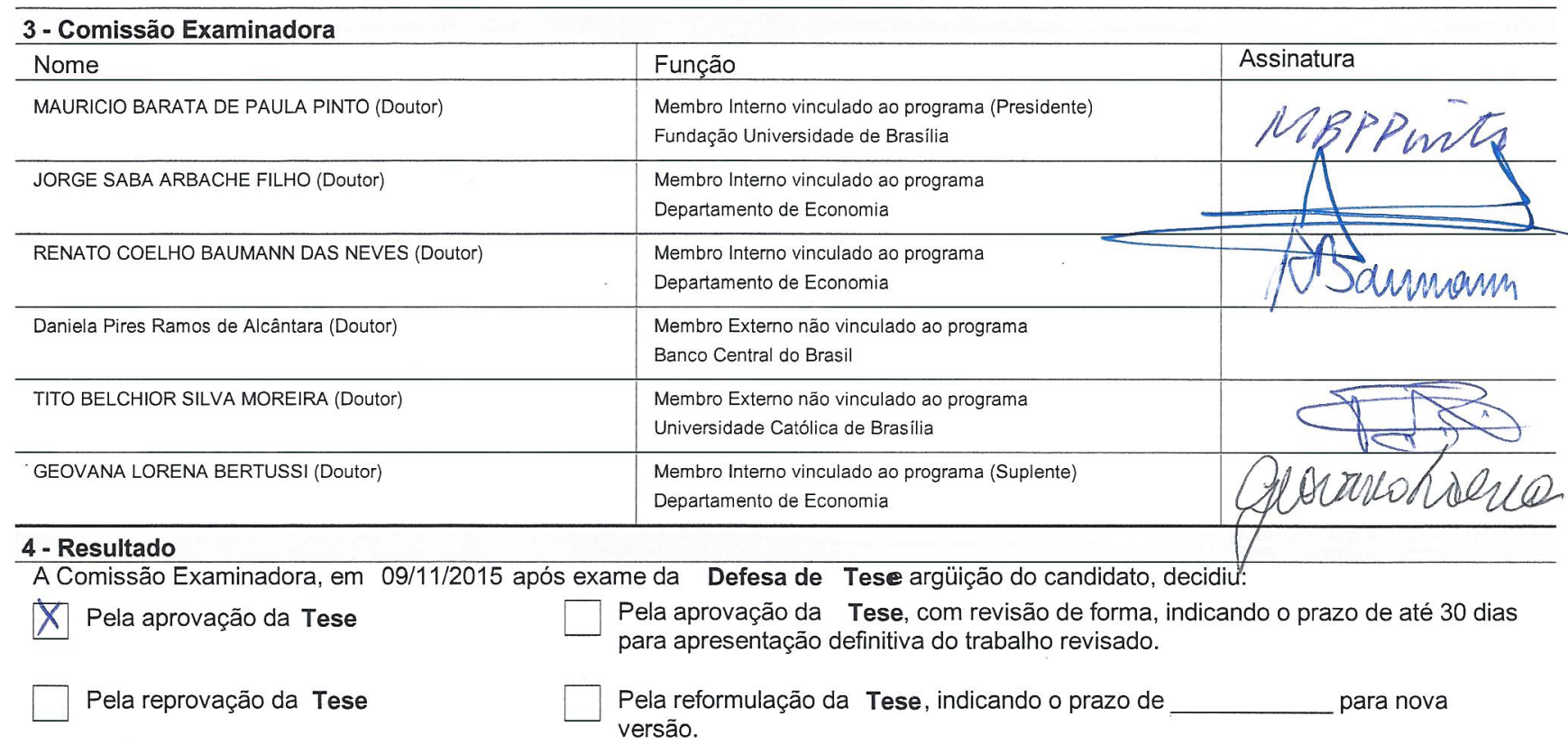

Preencher somente em caso de revisão de forma:

O aluno apresentou a revisão de forma e a Tese foi aprovada.

Autenticação

Presidente da Comissão Examinadora

O aluno apresentou a revisão de forma e a Tese foi reprovada.

O aluno não apresentou a revisão de forma.

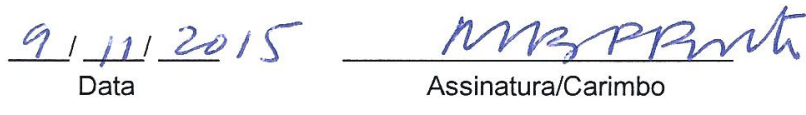

Autenticação

Coordenador do Curso

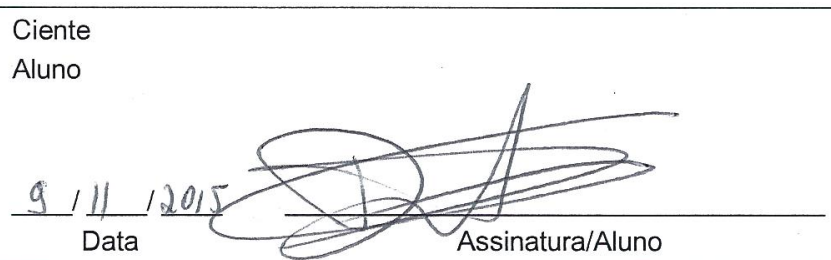

$\frac{1}{\text { Data }}$

Assinatura/Carimbo

Data

Este relatório não é conclusivo e não tem efeitos legais sem a aprovação do Decanato de Pesquisa e Pós-graduação da Universidade de Brasília.

\section{Aprovação do Decanato de Pesquisa e Pós-Graduação}

Decisão:

Homologar

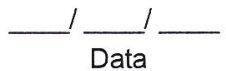


Para Amanda. 


\section{Agradecimentos}

O presente trabalho consolida um desenvolvimento intelectual e acadêmico pessoal, mas que somente se torna possível com o apoio e a participação de diversas outras pessoas, que, direta ou indiretamente, contribuem com parcelas para a sua construção.

Em especial, agradeço ao professor Maurício Barata de Paula Pinto que me orientou desde a construção do projeto de pesquisa e durante todo o processo de seu desenvolvimento, tendo sido um verdadeiro mentor nos últimos anos.

Agradeço também ao financiamento da pesquisa doutoral. Por meio do programa de pós-graduação do Banco Central do Brasil (Pt 1101539860), do programa de pós-graduação da Universidade de Brasília e do programa de doutorado sanduíche no exterior da fundação Coordenação de Aperfeiçoamento de Pessoal de Nível Superior-Capes (BEX 3818-14-4), tornou-se possível a realização da presente pesquisa. Espero que o esforço financeiro do contribuinte brasileiro se transforme em avanços significativos para a pesquisa na área de economia internacional no Banco Cental do Brasil.

Ao professor Ugo Panizza, agradeço pela orientação durante o período de pesquisa sanduíche no Institut de Hautes Études Internationales et du Développement e, aos professores Cédric Tille e Marc Flandreau, pelos inúmeros comentários e sugestões enquanto lá estive.

Aos professores Adriana Moreira Amado, Jorge Saba Arbache Filho, Maria Eduarda Tannuri-Pianto, Maurício Soares Bugarin, Renato Coelho Baumann das Neves e Roberto de Góes Ellery Júnior, agradeço por toda a orientação e apoio durante o período em que estive no departamento de economia.

À doutora Daniela Pires Ramos de Alcântra, agradeço pelo encaminhamento e acompanhamento técnico deste projeto junto ao Banco Central.

Aos senhores Ademir Julio Schenatto, Carlos Antônio Silva dos Santos, Glenn Frank Di Fiore, Herlon Alves Brandão, Paulo Marcelo Cavalcanti Muniz e Roberto Jorge Enrique de Souza Dantas agradeço pelo auxílio com os dados necessários e pelos esclarecimentos prestados, os quais tornaram possíveis os exercícios empíricos realizados.

Aos colegas Fernanda Ledo Marciniuk, Márcia Cristina Silva Paixão, Mário Rubem do Coutto Bastos e Oliveira Alves Pereira Filho, com os quais tive a oportunidade de 
dividir a sala durante programa de pós-graduação em economia da UnB, agradeço pelas longas - e, por vezes, calorosas - discussões sobre os mais diversos assuntos da economia. Espero ter igualmente contribuído com uma visão da economia internacional.

À minha mulher, Lídia, agredeço por sua incansável e paciente revisão dos mais diversos textos produzidos e, em especial, desta tese, cujas incorreções ou eventual falta de clareza remanescentes são de minha exclusiva responsabilidade e são decorrentes de minha incapacidade em atender às suas sugestões. Seu constante suporte é o que torna possível a realização e conclusão deste projeto.

Ao meus pais, agradeço pelos contínuos e incondicionais incentivo e apoio. 


\section{Resumo}

\section{Ensaios sobre a Internacionalização da Moeda}

O presente estudo consiste num conjunto de quatro ensaios que contribuem para a avaliação normativa de políticas de internacionalização da moeda, com foco no Brasil. O primeiro ensaio discute a precisão do termo "moeda internacional", o qual é comumente confundido com diversos conceitos, e destaca a aceitação internacional como sua característica fundamental, a qual chamamos de internacionalidade. O segundo ensaio analisa dados do comércio exterior brasileiro a fim de precisar o quanto o real brasileiro é aceito no mundo como moeda de faturamento. É estabelecido que, ainda que em pequena escala, a moeda brasileira é escolhida voluntariamente para faturar operações de comércio exterior. Ademais, o ensaio apresenta novos dados sobre questões que estão na fronteira das discussões internacionais sobre a escolha de moedas para o faturamento. Registra-se a relação entre a disponibilidade de instrumentos financeiros e a escolha da moeda de faturamento. Registra-se também a escolha de uma moeda não-internacional para o faturamento de produtos primários negociados em mercados internacionais, reforçando a hipótese de existência de poder de barganha na escolha da moeda de faturamento. Registra-se ainda a não coincidência do uso da mesma moeda para faturamento e para pagamento no caso brasileiro. O terceiro ensaio propõe que seja considerada a redistribuição de renda entre residentes como argumento para a adoção de políticas de internacionalização da moeda. No âmbito de países que induzem fortemente o uso da moeda nacional entre seus residentes - principalmente banindo o uso de moedas estrangeiras - a internacionalização da moeda pode minimizar os efeitos de redistribuição de renda entre setores e agentes residentes. Por fim, o ensaio quatro analisa a política de provisão de ordens de pagamento internacionais pelo governo, debruçando-se sobre o caso do Sistema de Pagamentos em Moeda Local (SML) entre Argentina e Brasil. Propõe-se que o SML é um método menos custoso de lidar com a restrição de liquidez da moeda local cujo uso é induzido pelo governo.

Palavras-chave: moeda internacional, uso da moeda, distribuição de renda, real brasileiro. 


\section{Abstract}

\section{Essays in Currency Internationalization}

This study is a set of four essays contributing to the normative assessment of currency internationalization policies, focusing on the Brazilian perspective. The first essay discusses the accuracy of the "international currency" term - which frequently blurs to various other concepts - and highlights the international acceptance as its fundamental property. We name this property as internationality. The second essay dwells on Brazilian foreign trade data in order to clarify the worldwide acceptance of the Brazilian real as an invoice currency. It is established that, although on a limited scale, the Brazilian currency is chosen voluntarily to invoice foreign trade transactions. Additionally, the essay presents new data on issues at the forefront of international discussions on the choice of currencies for invoicing. We establish the relationship between the availability of financial instruments and the invoice currency choice. We also register the choice of a non-international currency for invoicing primary products traded on international markets, supporting the bargain power hypothesis on the invoice currency choice. Yet, we register the mismatch between the currency chosen for invoicing and for payments in Brazil. The third essay purposes the wealth distribution between residents as an argument to be taken into account while appraising currency internationalization policies. Within countries that strongly induce the use of the national currency among its residents - especially banning the use of foreign currencies - the currency's internationalization may minimize the effects of income redistribution between sectors and resident agents. Finally, the fourth essay analyzes the government policy of providing international payment orders, tackling the case of the Local Currency Payment System (SML, on the Portuguese acronym) between Argentina and Brazil. It purposes the SML as a less-costly method to address the liquidity constraint of local currencies whose use is government-induced.

Keywords: international currency, currency use, income distribution, Brazilian real. 


\section{Lista de Figuras}

Figura 1 - Crescimento da participação das moedas (2007-11) . . . . . . . . . . . 49

Figura 2 - Variação cambial do BRL e do EUR em relação ao USD (2007-11) . 50

Figura 3 - Diagrama de interações econômicas e uso da moeda . . . . . . . . . . . 80

Figura 4 - Diagrama de interações econômicas e uso da moeda . . . . . . . . . . 81

Figura 5 - Curva de oferta na moeda local e na moeda internacional . . . . . . . 87

Figura 6 - Efeitos dos custos cambiais na oferta . . . . . . . . . . . 88

Figura 7 - Efeitos dos custos cambiais na demanda . . . . . . . . . . . . 91

Figura 8 - Efeitos de moedas não-internacionais no equilíbrio do mercado interno 93

Figura 9 - Curvas de oferta em diferentes níveis . . . . . . . . . . . . . . 97

Figura 10 - Ordem de pagamento SML-visão dos usuários . . . . . . . . . . . . 106

Figura 11 - Esquema interno do SML . . . . . . . . . . . . . . . . . . 109 


\section{Lista de Tabelas}

Tabela 1 - Diferente terminologia sobre a moeda e o cenário internacional . . . . . 28

Tabela 2 - Papéis internacionais de uma moeda . . . . . . . . . . . . . . . . 29

Tabela 3 - Participação da moeda no valor faturado nas exportações e importações brasileiras, por moeda, 2007-11 (\%) . . . . . . . . . . . 49

Tabela 4 - Exportações em reais para 12 principais países em valores, por país de destino $(2007-11) \ldots \ldots \ldots$. . . . . . . . . . . . . 52

Tabela 5 - Principais origens de importações brasileiras faturadas em BRL, por país $(2007-11) \ldots \ldots \ldots \ldots \ldots \ldots \ldots$

Tabela 6 - Comércio brasileiro faturado em BRL, por produto (2007-11) . . . . 56

Tabela 7 - Participação do faturamento em BRL no total do comércio, por produto e por país $(2007-11) \ldots \ldots \ldots$. . . . . . . . . . . 5 . 56

Tabela 8 - Exportações faturadas em BRL para a Argentina, por produto (2007-11) 59

Tabela 9 - SML e participação do faturamento em BRL nas exportações . . . . . 61

Tabela 10 - Exportações brasileiras de açúcar faturadas em BRL, por país (2007-11) 63

Tabela 11 - Exportações brasileiras de tabaco faturadas em BRL, por país (2007-11) 64

Tabela 12 - Relação entre operações financeiras relacionadas ao comércio denominadas em BRL e o comércio faturado em BRL, 2007-11 . . . . . . . . 66

Tabela 13 - Restrições comumente impostas pelos países na escolha de moeda pelos residentes . . . . . . . . . . . . . . . . . . . 78

Tabela 14 - Medidas de internacionalização do real da Lei 11.803 . . . . . . . . . . 104 


\section{Lista de abreviaturas e siglas}

ARS Peso argentino, moeda argentina

BCB Banco Central do Brasil

BCRA Banco Central de la República Argentina (Banco Central da República Argentina, tradução livre em português)

BRL Real, moeda brasileira

CCR Convênio de Pagamentos e Créditos Recíprocos

EUR Euro, moeda emitida pelo Banco Central Europeu

JPY Iene, moeda japonesa

MDIC Ministério do Desenvolvimento, Indústria e Comércio Exterior

SML Sistema de Pagamentos em Moeda Local

TIR Transferência Internacional de Reais

USD Dólar americano, moeda dos Estado Unidos da América 


\title{
Lista de símbolos
}

\author{
$\aleph \quad$ conjunto de registros contábeis \\ $\beth \quad$ conjunto de fatos contábeis \\ $c_{f} \quad$ moeda emitida por governo estrangeiro \\ $c_{h} \quad$ moeda nacional (emitida pelo governo local) \\ $d_{c_{f}} \quad$ função de demanda inversa em moeda local (custo de fatores) \\ $\bar{s}_{c_{h}} \quad$ função de oferta inversa com custos cambiais denominada em moeda \\ não-internacional \\ $s_{c_{f}} \quad$ função de oferta inversa em moeda local (custo de fatores) \\ $\bar{s}_{c_{f}} \quad$ função de oferta inversa com custos cambiais denominada em moeda \\ internacional
}




\section{Sumário}

Apresentação . . . . . . . . . . . . . . . . . . 15

I ENSAIO 1

1 A INTERNACIONALIDADE DA MOEDA . . . . . . . . 23

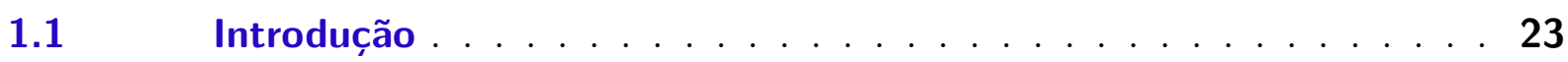

1.2 Internacionalidade e moedas internacionais . . . . . . . . . . . . 24

1.2.1 A confusão de funções: diversas funções, diversas medidas . . . . . . . . . 29

1.2.2 A confusão internacional . . . . . . . . . . . . . . . . . . 29

1.2.3 O relacionamento entre moeda e país . . . . . . . . . . . 30

1.2.4 Inter-nacional: uma economia de estados . . . . . . . . . . . . . . 31

1.2.5 Áreas monetárias e o território dos países em economia . . . . . . . . . . 34

1.2.6 Moedas supranacionais e internacionais . . . . . . . . . . . 35

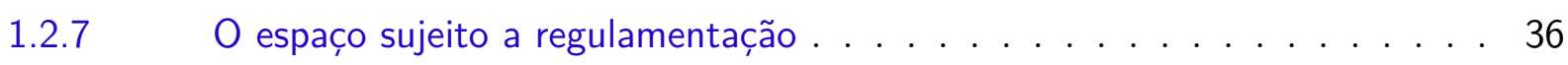

1.2 .8 Nossa formulação . . . . . . . . . . . . . . . . . . . . . 37

$1.3 \quad$ Comentários finais $\ldots \ldots \ldots \ldots \ldots$

$\begin{array}{lll}\text { II } & \text { ENSAIO } 2 & 39\end{array}$

2 A MOEDA DE FATURAMENTO DO COMÉRCIO EXTERIOR BRA-

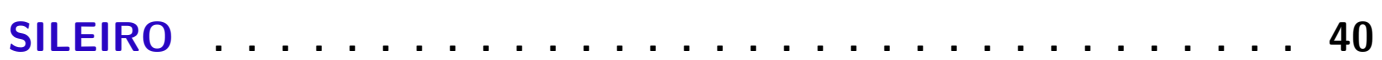

$2.1 \quad$ Introdução . . . . . . . . . . . . . . . . 40

2.2 Internacionalização da moeda e moedas veículo . . . . . . . . . 42

2.3 Dados e metodologia . . . . . . . . . . . . . . . . . 44

2.3.1 Dados de comércio . . . . . . . . . . . . . . . . . . . . . . 44

2.3.2 Dados financeiros relacionados ao comécio . . . . . . . . . . . . . . 46

2.3.3 Definição de moeda internacional . . . . . . . . . . . . . . . 47

$2.4 \quad$ Moedas de faturamento no comércio exterior brasileiro . . . . . . 47

2.5 Panorama do comércio faturado em BRL . . . . . . . . . 50

2.5.1 O faturamento em BRL se tornou mais comum . . . . . . . . . . . . 51

2.5.2 Significante impacto da introdução do sistema de pagamentos . . . . . . 57

2.5.3 Há coincidência das moedas de faturamento e de pagamento? . . . . . . 65

$2.6 \quad$ Comentários finais . . . . . . . . . . . . . . . . 67 

DISTRIBUIÇÃO DE RENDA . . . . . . . . . . . . . 71

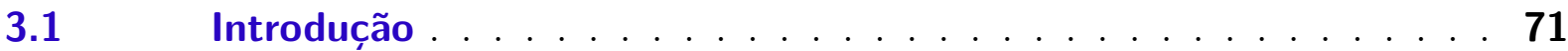

3.2 A restrição de uso de moedas estrangeiras e a internacionalidade da moeda . . . . . . . . . . . . . . . . . . . . . 74

3.2.1 O relacionamento biunívoco entre país e moeda . . . . . . . . . . 74

3.2.2 A moeda nacional e os residentes . . . . . . . . . . . . . 75

3.2.3 A moeda nacional e os não-residentes . . . . . . . . . . . . 78

3.2.4 Moeda e residência: indução da moeda e internacionalidade . . . . . . . . . 79

$3.3 \quad$ A moeda de referência . . . . . . . . . . . . . . . . . . 82

3.4 Efeitos de uma moeda não ser aceita internacionalmente . . . . . 86

3.4.1 Interação econômica entre agentes residentes e não-residentes . . . . . . 86

3.4.2 Interação econômica entre residentes . . . . . . . . . . . . . . . 92

3.4.3 Discussão . . . . . . . . . . . . . . . . . . . . . . . 95

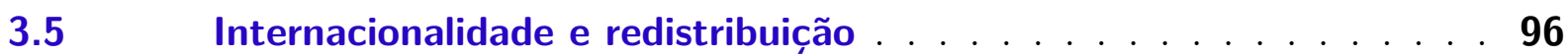

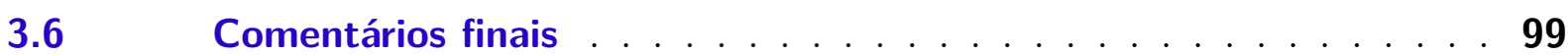

$\begin{array}{lll}\text { IV } & \text { ENSAIO } 4 & 100\end{array}$

4 UMA EXPERIÊNCIA INCIPIENTE DE INTERNACIONALIZAÇÃO 101

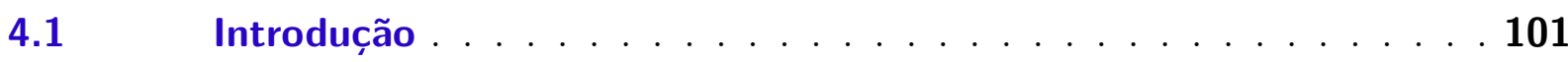

$4.2 \quad 0$ sistema de pagamentos . . . . . . . . . . . . . . . . 103

4.2.1 Contexto de adoção do sistema . . . . . . . . . . . . . . . . . . 103

$4.3 \quad$ A descrição do sistema . . . . . . . . . . . . . . . 105

4.3.1 Perspectiva para os usuários: uma ordem de pagamento com câmbio associado105

$4.4 \quad$ Volatilidade da moeda e incerteza de preços . . . . . . . . . 110

$4.5 \quad$ A predileção pela intervenção do SML . . . . . . . . . . . . 115

4.6 Comentários finais . . . . . . . . . . . . . . . . . . 117

Considerações finais $\ldots \ldots \ldots \ldots \ldots \ldots \ldots \ldots$

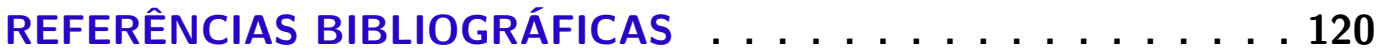




\section{Apresentação}

O conjunto de ensaios integrante deste estudo procura contribuir para a discussão normativa sobre a pertinência de uma política brasileira de internacionalização da moeda. Por política de internacionalização da moeda, entende-se a ação pública empreendida a fim de alterar favoravelmente a percepção das funções da moeda nacional por agentes não residentes.

Funções da moeda é a designação dos papéis desempenhados por uma moeda na economia. É extensa a literatura que discute estas funções e não nos concentraremos neste debate. De forma geral, existem três funções consagradas para a moeda: meio de troca, reserva de valor e unidade de conta. Estas funções consagradas são suficientes para a discussão proposta neste estudo, sem nenhuma perda de generalidade. A pesquisa desenvolvida nos quatro ensaios que se seguem está concentrada na compreensão e desempenhos destas funções sobre agentes não-residentes no território que emite uma moeda. Neste ambiente, as decisões soberanas de um estado em impor que um agente utilize uma determinada moeda (geralmente aquela de sua própria emissão) em determinadas situações, o que se conhece por curso forçado, e em vedar a utilização por um agente de moedas que não sejam aquela de sua emissão são de essencial relevância.

Entende-se como moeda internacional aquela que apresenta ao menos algumas de suas funções de moeda, em algum grau, internacionalmente aceitas fora do território da autoridade emissora da moeda. Definimos "internacionalidade" como a propriedade multidimensional de uma moeda ter suas funções reconhecidas além das fronteiras do território sujeito à autoridade de seu estado emissor. Cada uma das funções da moeda pode ser avaliada sobre cada dimensão da propriedade de internacionalidade. A definição deste termo, que é explorada no ensaio 1, procura conferir maior precisão à discussão que se intenciona propor, evitando os conflitos decorrentes da falta de uniformidade das definições existentes para os conceitos de moeda internacional, moeda conversível, moeda reserva, moeda veículo, entre outras.

Alguns esclarecimentos se fazem necessários. Admite-se que o termo moeda conversível tem seu significado enfatizando a aceitação das trocas da moeda em questão por uma outra de liquidez confirmada. Assim, distingue-se a característica de internacionalidade por sua ênfase na percepção do agente sobre o nível de aceitação da moeda em relação às suas funções. Uma distinção entre os conceitos de conversibilidade monetária e de internacionalização monetária é feita por Genberg (2011), que associa aquele termo a 
aspectos de liquidez e este a aspectos relacionados ao uso da moeda.

O escopo do estudo não atinge tampouco a discussão da substituição de moedas que apresentem característica de predominância no cenário internacional. Neste sentido, ressalta-se que moeda internacional não é vista nem como uma característica dicotômica, nem como a construção de uma pirâmide de classificação de moedas que segmentem sua importância no cenário mundial quanto mais se aproximem do seu topo (COHEN, 2000b; COHEN, 2012). Moeda internacional é compreendida como um espaço contínuo de dimensões equivalentes às funções tipicamente desempenhas pela moeda. Reafirma-se, pois, que o foco é a análise de políticas que contribuam para o aumento da aceitação de uma moeda nacional no plano internacional. Este nível de aceitação, entretanto, pode variar desde entre algumas ocorrências específicas entre agentes para determinadas funções da moeda até o uso generalizado internacionalmente. Para o estudo, o que importa é o aumento ou redução do reconhecimento dos agentes não residentes sobre as funções de uma moeda e não a rivalidade existente entre duas moedas distintas.

A característica internacional da moeda tem sido discutida na literatura em momentos distintos de acordo com diferentes visões que buscam responder aquelas questões que são mais relevantes para as discussões de seus tempos. Um exemplo é a ascensão do dólar americano como moeda de referência internacional no lugar da libra esterlina e do ouro para efeitos de transações e como moeda de reserva. A relevância do Federal Reserve System neste processo de internacionalização do USD é registrada por Eichengreen e Flandreau (2012). O lançamento de uma moeda emitida por uma autoridade monetária supranacional - o euro - substituindo as antigas opções locais, cujo reconhecimento internacional era tido em certa medida, e seu potencial de rivalizar ou substituir a moeda líder global é outro exemplo de discussões nos momentos de constituição do euro e de sua avaliação após uma década de seu lançamento. E ainda são exemplos da Ásia, o destaque do iene junto com a aceleração da economia japonesa na década de 1990 e, mais recentemente, as políticas da China para o renminbi, seguindo a elevação do status global da economia chinesa.

As vantagens e desvantagens de se ter uma moeda internacional têm sido objeto de investigação. Senhoriagem e redução dos custos de transação são as duas principais consequências ponderadas em relação a um país emitir uma moeda que apresente características internacionais. Outros argumentos debatidos são: a conveniência para residentes; o estímulo ao sistema financeiro nacional; a flexibilidade macroeconômica; a existência de restrições à facilidade de condução da política monetária - enquanto Papaioannou e Portes (2008) afirmam não existir evidências empíricas de maior dificuldade, Frankel (2012) argumenta que maiores flutuações na demanda pela moeda tornam mais difícil a condução da política monetária —, reputação (soft power), influência política (hard 
power); a existência de restrições externas (existência de pecado original); a responsabilidade política associada e a apreciação do valor da moeda com o aumento da sua demanda média.

Papaioannou e Portes (2008) consolidaram os argumentos existentes em um estudo que teve como objeto central a avaliação do euro, moeda que serve de referência para a maioria dos estudos acadêmicos que analisam questões relacionadas a moeda nas últimas duas décadas. Trata-se de um experimento monetário sem comparação por se tratar da criação de uma moeda supra nacional que envolve mais de uma dúzia das mais desenvolvidas economias mundiais; e ainda em um espaço de expansão que inclui grandes contrastes e incorpora em ritmo relativamente acelerado novas economias nas décadas posteriores. Kannan (2009) focou aspectos normativos, apresentando um modelo que permitia quantificar os benefícios de um país ao disseminar o uso de sua moeda. $\mathrm{O}$ lançamento do euro como uma moeda comum supranacional foi o estímulo destas análises.

Também já foram objetos de estudos os fatores que impactam a internacionalidade de uma moeda. A força de economia e tamanho do mercado, a previsibilidade da moeda em relação à estabilidade de seu poder de compra e de sua taxa de câmbio, a existência de mercados financeiros desenvolvidos e eficientes para a moeda causando menores custos de transação e a existência de externalidades de rede são os principais fatores apontados.

A literatura também já se ocupou de tentar encontrar um espaço geoeconômico ótimo de emissão para uma moeda. No bojo de discussões acerca de regimes cambiais iniciadas por Mundell (1961) e McKinnon (1963), o caminho pavimentado pela discussão sobre áreas monetárias ótimas sugere a existência de relativa dissociação entre o espaço monetário e o espaço estatal. Nos anos recentes, a China tem se empenhado oficialmente em uma política de internacionalização de sua moeda, o renminbi. Grande parte de sua motivação, entretanto, pode ser atribuída primordialmente a uma estratégia política e os ganhos desta estratégia são constituídos pela realização de expectativas referentes a relações de poder econômico entre os países (VOLZ, 2013). A racionalidade desta ideia se relaciona, no campo teórico, a considerações da expressão de um poder monetário internacional (ANDREWS, 2006b; COHEN, 2006; KIRSHNER, 2006).

O presente estudo se concentra mormente em questões econômicas. Ainda que a avaliação de custos e benefícios seja fundamental e seja tomada como base, nosso intento é ponderar se o engajamento de um país em uma política de internacionalização da moeda pode produzir um ganho de bem-estar social uma vez corrigida alguma distorção criada pela não internacionalidade da moeda.

Na literatura econômica brasileira, as discussões sobre uma moeda não restrita ao 
território nacional foi tratada em duas vertentes principais. A primeira lidou essencialmente com a questão de uma moeda comum para os países do Mercosul ou entre Brasil e Argentina. Este exercício acadêmico se relacionou historicamente com o período de lançamento do euro e o principal marco teórico utilizado foi a teoria de áreas monetárias ótimas. Os autores não encontram convergência macroeconômica entre os países (FILHO; PAULA, 2002; CHAGAS, 2004) e sugerem que a adoção de uma moeda só faria sentido num processo de integração maior, similarmente ao ocorrido na Europa, sendo a política o principal fator decisório (EICHENGREEN, 1998; GIAMBIAGI, 1998; GIAMBIAGI; BARENBOIM, 2002), algo que não diferiu de achados anteriores (KAFKA, 1973). Diferentemente, estudos empíricos de Engle e Issler (1993) e Basnet e Sharma (2013) encontram um sincronismo macroeconômico entre as principais economias da Amércia Latina, sugerindo estes poder contribuir para um processo de integração econômica regional. Ainda na primeira linha de pesquisa, Giambiagi (1997) apresenta uma proposta pragmática de unificação monetária para os países do Mercosul com um cronograma de implementação que seguiria desde 1998 até a adoção da moeda única em 2012. Em um raro estudo estimativo de custos, Chagas e Baumann (2007) avaliam uma economia de USD 601 milhões por ano com custos de transação em decorrência da adoção de uma moeda única. A mesma linha de redução de custos de transação é seguida por Gnos, Monvoisin e Ponsot (2009), mas estes autores, entretanto, também entendem a participação do Brasil em uma união monetária regional como uma forma de reduzir a dependência de assimetrias norte-sul e de reduzir a dependência do dólar americano. Esta linha de argumentação adicionada pelos autores, já se distancia do momento de lançamento do euro ocorrido no início da década e se insere no contexto das discussões de políticas de integração regional ocorridas na América do Sul a partir dos últimos anos da mesma década. Bresser-Pereira e Holland (2009) argumentam que a falta de uma moeda comum ou, pelo menos, de uma coordenação de taxas de câmbio é um entrave para o avanço regional, ainda que alertem para o fato de ser prudente o aumento da integração econômica previamente ao estabelecimento de uma coordenação cambial.

Uma segunda linha de debate na literatura brasileira se deu mais próxima aos problemas do relacionamento da moeda brasileira com o mundo e discute a conversibilidade da moeda nacional como sustentação para a estabilidade da economia, o que é proposto pelas argumentações de Arida (2003a), Arida (2003b) e de Bacha (2003). Os autores entendem a convertibilidade como a ausência de barreiras legais à livre conversão cambial e sugerem que a sua garantia institucional proporcionaria menores taxas de juros a serem pagas pelos títulos brasileiros. Na direção oposta à convertibilidade plena brasileira, seguem Oreiro, Paula e Silva (2004) - sugerindo a manutenção de controles seletivos de capitais - e Ferrari-Filho et al. (2005), sugerindo que a plena conversibilidade da moeda aumentaria o risco cambial do real a patamares indesejáveis. Ainda outra tentativa da associação da 
inconversibilidade da moeda é feita com aspectos decorrentes de incerteza jurisdicional, o que levaria às altas taxas de juros pagos pelo país. Isto é argumentado por Arida, Bacha e Lara-Resende (2005), mas não é confirmado empiricamente por Gonçalves, Holland e Spacov (2007).

É interessante notar que Arida (2003a) sustenta que a percepção dos agentes de o real ainda ser uma moeda de segunda classe é o que permeia os argumentos contrários à livre conversibilidade. Mas ao mesmo tempo que sugere reduzir entraves burocráticos para a conversibilidade do real, reafirma barreiras à utilização de moedas estrangeiras no território nacional a fim de garantir, ao menos, ganhos com senhoriagem (ARIDA, 2003b). Neste ponto, observamos que a compreensão da moeda como tal pelos agentes - residentes e não residentes - está a parte desta discussão e o distanciamento entre conversibilidade e internacionalidade argumentados anteriormente resta destacado. Ao se preocupar com ganhos de senhoriagem, o foco da otimização econômica resta sobre a unidade econômica nacional e não sobre o agente econômico e as distorções decorrentes sobre suas decisões causadas pelas imposição da moeda nacional, o que é objeto neste trabalho.

Também contrários à proposta de conversibilidade plena do real discutida pelos demais autores nesta segunda linha de debate, Belluzzo e Carneiro (2004) ressaltam distinção existente entre a conversibilidade plena e a conversibilidade efetiva da moeda. Enquanto a conversibilidade plena é discutida no sentido de haver uma garantia institucional para que a moeda nacional seja convertida, a conversibilidade efetiva estaria relacionada à utilização dos diversos agentes da moeda nacional como reserva de valor no plano internacional. Embora considerem apenas a função de reserva de valor da moeda, a ideia de conversibilidade efetiva é a que mais se relaciona à discussão da característica de internacionalidade proposta neste estudo.

Aqui, nosso interesse principal está nas discussões de inserção internacional do Brasil. Os resultados serão apresentados em 4 ensaios que contribuem para a discussão, ampliando-a em 4 fronteiras harmônicas e interdependentes. Em uma primeira linha, nós exploramos uma face conceitual, debruçando sobre o conceito de moeda internacional. Uma variedade de termos é recorrentemente empregada para representar, em alguma medida, a condição de uma moeda no cenário internacional. Entretanto, a ausência de uma precisão conceitual dificulta - senão impede - que o debate relacionado seja tido de forma consistente. A contribuição do ensaio está em consolidar um arcabouço conceitual para os debates acerca de moedas internacionais. Propomos, então, o termo internacionalidade para representar a característica de uma moeda no cenário internacional e discutimos as diversas acepções que estão envolvidas em sua formação. Destacamos também o papel do estado e do exercício de sua soberania como aspectos fundamentais na distinção entre moedas nacionais e moedas internacionais. 
Em uma segunda linha, seguimos por uma avaliação empírica e descrevemos o panorama de utilização da moeda brasileira no faturamento do comércio nacional a partir de dados do Ministério do Desenvolvimento, Indústria e Comércio Exterior (MDIC), atividade anteriormente ainda não realizada na literatura econômica nacional. Este ensaio utiliza pela primeira vez dados do comércio exterior brasileiro detalhados por país, produto e moeda para descrever o uso do real no comércio exterior brasileiro. São apresentadas contribuições para a literatura em duas perspectivas distintas. Na perspectiva voltada para questões relacionadas ao Brasil, afasta-se definitivamente a ideia de que o real não é utilizado voluntariamente além das fronteiras nacionais. Ainda que seu uso seja reduzido quando comparado ao total de exportações e importações, o crescimento do real como moeda de faturamento é expressivo. A consolidação desta ideia nos permite sugerir novas questões a serem desenvolvidas no debate brasileiro sobre a utilização do real internacionalmente. A segunda perspectiva está relacionada a contribuições que estão na fronteira das discussões sobre a escolha da moeda de faturamento no mundo. Nós constatamos que a política brasileiro-argentina de prover ordens de pagamento associadas a operações de câmbio entre suas moedas teve um impacto significativo sobre a moeda escolhida para o faturamento, estabelecendo uma ligação entre a disponibilidade de instrumentos financeiros e a escolha da moeda. Além disso, as evidências não confirmam alguns resultados internacionais anteriormente constatados. Nós identificamos que, no Brasil, não há coincidência entre a moeda utilizada para faturar e para efetuar pagamentos. Ademais, observamos que as principais exportações faturadas em BRL são de produtos homogêneos (açúcar e tabaco), sugerindo que reste algum poder de barganha ainda que os produtos sejam comercializados em mercados internacionais.

A terceira linha se concentra em explorar uma questão teórica, permitindo a ampliação da análise de vantagens e desvantagens da utilização de uma moeda internacional. Políticas de internacionalização da moeda retornam ao centro dos debates de tempos em tempos. Ainda que diversas vantagens e desvantagens acerca destas políticas já tenham sido largamente consideradas na literatura, um fato que tem sido negligenciado é que tais políticas têm impactos nos efeitos redistributivos advindos da decisão de um país ter sua própria moeda. Quando consideramos que um país ter uma moeda não é uma decisão econômica, mas é uma decisão política, as consequências redistributivas se tornam claras. Uma maior internacionalidade da moeda proporciona que mais agentes aceitem a moeda nacional, em especial aqueles agentes que não podem ser constrangidos pelo governo emissor a utilizá-la. Para países como o Brasil, o qual focamos aqui, como para a China, que tem a internacionalização de sua moeda como assunto em aberta discussão na atualidade, a maior internacionalidade da moeda emitida pode amenizar os efeitos distributivos entre os seus agentes residentes.

Tendo o aspecto redistributivo avaliado, partimos para avaliar uma política de 
governo que disponibiliza instrumentos financeiros em moedas de baixa internacionalidade. Esta quarta linha de análise foca a experiência brasileira. A análise apresentada propõe uma nova linha de argumentação: o Sistema de Pagamentos em Moeda Local (SML) é tomado como um instrumento financeiro inovador devido à associação de uma operação de câmbio a uma ordem de pagamento e se concentra em sua razoabilidade monetária. Fazemos a análise sob este ponto de vista pela primeira vez, visto que todos os estudos anteriores se concentraram em aspectos relacionados à integração e ao comércio exterior. Avaliamos a introdução do SML como política para tratar dos efeitos redistributivos consequentes da indução de uma moeda nacional, principalmente por meio do banimento do uso de moedas estrangeiras em território nacional. Concluímos que o sistema, segundo proposto pelos bancos centrais da Argentina e do Brasil, é uma maneira menos onerosa de tratar as consequências da política de preferência garantida à moeda nacional. 
Parte I

Ensaio 1 


\section{A internacionalidade da moeda: avanços teóricos para compreensão da moeda além de fronteiras}

\subsection{Introdução}

Moeda internacional é um termo comum na literatura econômica. Muitos diferentes aspectos instigam acadêmicos a estudarem o uso da moeda e os limites de seu uso em relação às fronteiras. Interesses sobre qual é a moeda escolhida no comércio internacional, sobre qual é a moeda utilizada como ativo de reserva internacional e sobre a fragilidade das economias como consequência da moeda em que conseguem denominar seu endividamento externo são alguns exemplos das principais questões relacionadas ao uso da moeda no cenário internacional.

Ainda que seja um termo largamente utilizado, "moeda internacional" é normalmente associado a diferentes conotações, dependendo do ponto de vista que está em análise em uma determinada pesquisa. Esta situação traz desafios adicionais às pesquisas que investigam a moeda em sua dimensão internacional. A indefinição conceitual proporciona uma situação em que diferentes definições são empregadas em diferentes estudos, tornando-se trabalhosa a comparação entre eles e facilitando a ocorrência de interpretações comparativas equivocadas.

Pesquisas recentes apresentaram uma ampla variedade de interpretações para a expressão "moeda internacional". Frankel (2012, 330) a formula de uma maneira ampla e a designa como a moeda "que é utilizada fora de seu país de origem". Uma visão mais específica é oferecida por Kenen $(2011,9)$. Em sua visão, "uma moeda internacional é uma que seja usada e tida além das fronteiras do país emissor, não apenas para os residentes daquele país, mas também, e substancialmente, para transações entre não residentes". Diferenças de entendimento do termo não estão limitadas à extensão da definição. Kannan (2009, 588), por exemplo, usa uma moeda internacional como "meio de troca nas transações internacionais", enquanto Flandreau e Jobst (2009) e Eichengreen e Flandreau (2012) utilizam o termo para distinguir uma moeda que seja globalmente dominante.

Independentemente do conceito que escolhamos, por sua extensão direta, um processo de internacionalização é aquele que aprofunda o uso internacional de uma moeda. Não obstante, o processo de internacionalização também é entendido como o processo que 
levaria a moeda a um status de domínio global e predominância sobre as demais moedas, como observa-se, por exemplo, em Eichengreen e Kawai (2014). Outras sobreposições que também são comuns para o termo moeda internacional acontecem com termos que observam a moeda em apenas uma de suas dimensões, como a moeda utilizada para faturar o comércio (moeda de faturamento); como a moeda usada como ativo de reserva (moeda reserva); e como a moeda para a qual não há restrições de câmbio (moeda conversível).

Desafios adicionais trazidos pela imprecisão do termo se tornam claros quando observamos o tratamento dado por Moss (2011), por exemplo. Ele sugere que, para as discussões relativas ao caso do euro, uma moeda internacional deve ser entendida como a moeda usada por não-residentes do conjunto de países emissores (aqueles integrantes da zona do euro).

"Conceitos são essenciais para o funcionamento e evolução das ciências sociais" (GERRING, 1999, 359). A precisão conceitual permite que diferentes esforços em uma mesma área de pesquisa possam contribuir harmosionamente para o progresso do conhecimento. Neste artigo, nós nos debruçamos sobre o conceito de moeda internacional em 3 seções. Após esta breve introdução, nós propomos, na próxima seção, o termo internacionalidade para representar a condição internacional de uma moeda e discutimos um arcabouço unificado no qual esta propriedade provê um interpretação adequada para o termo moeda internacional. A seção 1.3 conclui.

\subsection{Internacionalidade e moedas internacionais}

De forma a discutir as diferentes extensões do conceito de moeda internacional, vamos nos debruçar, primeiramente, sobre a característica que torna uma moeda ser considerada internacional. Nós a chamamos de internacionalidade e a definimos:

Definição 1 Internacionalidade é a propriedade de uma moeda ter suas funções de moeda reconhecidas além do domínio que está sujeito à regulação de sua autoridade emissora.

Nossa recém apresentada definição enfatiza aquilo que permite a um instrumento emitido se tornar moeda: o comportamento dos agentes para com ele. Assim, não é o fato de um emissor rotular algum instrumento como uma moeda que lhe confere valor. Ao invés disso, um instrumento se torna moeda quando os agentes o percebem como tal. ${ }^{1}$

1 Observe que não é necessário que o agente faça uso de uma determinado moeda, mas que ele reconheça a capacidade desta moeda ser potencialmente utilizada por ele. É o estado psicológico de o agente acreditar que o instrumento fiduciário em questão pode exercer (para ele) a função de meio de troca, de unidade de conta, de reserva de valor, ou uma combinação delas. 
Não é relevante, para nossa análise sobre moedas internacionais, portanto, identificar se os agentes têm conhecimento de uma instituição ter emitido algum instrumento e o ter denominado moeda. Nossa análise está centrada em identificar se um agente confere uma probabilidade positiva de o instrumento emitido lhe servir para alguma das funções da moeda. A internacionalidade surge então dos agentes que não estão sujeitos a nenhum tipo de regulamentação que conduza à aceitação ou à utilização de uma moeda a considerarem utilizá-la.

Estudos monetários têm geralmente sugerido o reconhecimento ${ }^{2}$ como sendo uma propriedade da moeda (WILLIAMSON; WRIGHT, 2010). Ainda que esta propriedade esteja relacionada à habilidade dos agentes de distinguirem ativos de boa qualidade daqueles ativos de má qualidade(LESTER; POSTLEWAITE; WRIGHT, 2012), ela é normalmente associada a interpretações mais restritas e diretas, como a identificação da falsificação de cédulas (DUTU; NOSAL; ROCHETEAU, 2005). Na medida em que esta interpretação não seja a utilizada, a internacionalidade pode ser interpretada como alguma forma de reconhecimento no sentido de ser a percepção de um agente que não está sujeito à imposição de uso desta moeda por seu governo. Internacionalidade é a capacidade de um agente identificar se alguma moeda estrangeira desempenha-para ele - adequadamente alguma das funções da moeda.

Assim, podemos definir uma moeda internacional a partir do conceito de internacionalidade: moeda internacional é uma moeda que tem suas funções da moeda reconhecidas além do domínio que está sujeito à regulação de sua autoridade emissora. Assim, temos:

Definição 2 Moeda internacional é aquela que possui suficiente internacionalidade.

Observe que estas definições de imediato desfazem a primeira sobreposição conceitual ao dissociar a característica de uma moeda estar presente no cenário internacional do status de uma moeda possuir ou não esta característica. No presente artigo, não objetivamos estabelecer uma medida que seja o limite para a garantia de um "status internacional" para uma moeda ${ }^{3}$. Ao invés disto, concentramo-nos em delinear o que "ter um alcance internacional" significa para uma moeda. Objetivamos compreender, discutir e definir a

2 Tradução livre do termo original recognizability. Não há, de acordo com o conhecimento deste autor, utilização de termo em português para representar esta propriedade até o momento presente.

3 Neste sentido, a explicitação do nível suficiente para uma moeda ser considerada internacional decorre de pesquisas posteriores. Aduz-se claramente, entretanto, que este nível é distinto entre as diverentes acepções do termo "moeda interncaional". Caso a acepção equivalha ao status de uma moeda globalmente dominantes, o nível suficiente para a identificar será superior àquele em que a acepção indique a propriedade de uma moeda ser utilizada fora de seu estado emissor, considerados os diferentes possíveis níveis de suficiência segundo às distintas dimensões funcionais da moeda. 
internacionalidade. Este é um primeiro passo no sentido de clarificar o entendimento do termo moeda internacional; o estabelecimento de uma medida para representar o quanto uma moeda está presente no cenário internacional permanece para futuras análises.

Buscamos para "moeda internacional" uma definição tão estrita quanto a sugerida por Kenen (2011) e apresentada na seção anterior. A definição que buscamos, entretanto, deve ser suficientemente ampla para nos permitir discutir moedas em um ambiente no qual nem estados sejam os únicos atores internacionais nem o relacionamento biunívoco entre moedas e países precise ser mantido. Considerar estados como atores exclusivos no cenário internacional é uma hipótese chave corriqueira na economia que compromete discussões sobre um mundo globalizado - um mundo integrado em que os limites dos estados não sejam limites absolutos e impenetráveis para as interações entre os agentes econômicos. Desconsiderar a distinção entre estados e moedas é a fonte de várias inespecificidades conceituais que identificamos.

Portanto, nós começamos nossa análise do conceito mais amplo em que moeda internacional designa a moeda que é utilizada fora de seu país de origem (FRANKEL, 2012). Este é um conceito amplo. Entretanto, está aberto a um grande conjunto de considerações quando tentamos caracterizar uma moeda como sendo internacional. Primeiramente, ser usada fora de seu país de origem - ou, em uma interpretação mais geral, ser usado além do território sobre o qual a sua autoridade monetária emissora tem jurisdição - é uma explicação generalista. Ela agrupa moedas que são largamente utilizadas - como o dólar americano é na atualidade - e moedas que são aceitas apenas em algumas situaçõesmoedas que são utilizadas apenas para pequenos pagamentos em cidades de fronteira, por exemplo. Assim, um grau que mensure o quanto uma moeda é aceita parece ser necessário. Em segundo lugar, uma moeda pode ser aceita como meio de troca como em nosso exemplo anterior. A mesma moeda, entretanto, pode não ser vista como uma reserva de valor e o comerciante pode buscar trocá-la por outra moeda ou ativo tão logo ele possa. A percepção de uma moeda como reserva de valor pode ser (ao menos) distinta entre agentes internacionais. Observamos, assim, que uma moeda pode ter diferentes níveis de quanto ela é internacional, dependendo da função a partir da qual ela é analisada. Terceiro, a área que nós consideramos como país de origem pode não ser tão precisa como observada em um primeiro momento e ainda o relacionamento biunívoco entre a área de aceitação e um país pode não ser adequado para todas as possibilidades. O conceito de o que é internacional deve ser analisado quando se discute moedas. A necessidade desta análise decorre da ambiguidade do que vem a ser nacional para uma moeda. É obrigatório que exista um relacionamento biunívoco entre uma moeda em um país? A resposta a esta indagação parece ser claramente negativa. Ainda assim, este relacionamento está presente no debate corriqueiro e é o ponto de partida para alguns dos principais resultados econômicos obtidos em relação a este tópico. Quarto, moedas em um sistema privado 
de câmbio - como o CLS - podem ser consideradas internacionais, enquanto as mesmas moedas podem não ser consideradas internacionais por governos, como para a liquidação de pagamentos entre governos, por exemplo. Assim como neste exemplo que distingue agentes privados e governos, o reconhecimento internacional de uma moeda pode variar de um agente para outro.

O grande número de diferentes entendimentos do termo moeda internacional é portanto explicado pelos diversos pontos de vista a partir dos quais a dimensão internacional da moeda pode ser percebida, de acordo com as diferentes funções que a moeda pode exercer e de acordo com a variação de percepção sobre o que é internacional. A tabela 1 consolida algumas das expressões mais comuns associadas ao termo moeda internacional e explicita a turvidez que ocorrem em relação a precisão dos termos associados à compreensão de moeda internacional. 
Tabela 1 - Diferente terminologia sobre a moeda e o cenário internacional

\begin{tabular}{|c|c|c|}
\hline Termo & Principal significado & Dimensão \\
\hline moeda local & moeda utilizada em um país ou em um arranjo subnacional & \\
\hline moeda doméstica & moeda utilizada em uma economia & \\
\hline moeda nacional & moeda utilizada em uma economia ou emitida por um país & \\
\hline moeda estrangeira & moeda utilizada fora de um país de referência & \\
\hline moeda supranacional & moeda emitida por mais de um país & \\
\hline moeda de faturamento (invoice currency) & moeda utilizada para o faturamento de operações comerciais & $\mathrm{UC}$ \\
\hline moeda veículo & $\begin{array}{l}\text { moeda utilizada, ao invés das moedas nacionais dos países envolvidos, para interações econômicas } \\
\text { no espaço internacional }\end{array}$ & MT \\
\hline moeda exótica & moeda que não apresenta liquidez nos mercados internacionais & \\
\hline moeda reserva & moeda utilizada por um governo como reserva de valor em ativo estrangeiro & RV \\
\hline moeda conversível & moeda que pode ser trocada por outras moedas sem limitações impostas pelo governo emissor & MT \\
\hline moeda regional & moeda suficientemente utilizada por um conjunto de países em uma dada região & \\
\hline moeda comum & $\begin{array}{l}\text { moeda emitida por uma autoridade monetária cujo seu território se expande por um território } \\
\text { maior que um país }\end{array}$ & \\
\hline moeda de denominação & $\begin{array}{l}\text { moeda utilizada para denominar o comércio (moeda de faturamento) ou denominar transações } \\
\text { financeiras }\end{array}$ & $\mathrm{UC}$ \\
\hline moeda global & moeda que é suficientemente aceita no mundo pela maioria de suas funções da moeda. & \\
\hline pecado original & $\begin{array}{l}\text { relacionado a moeda que não é reconhecida como possível de denominar dívidas soberanas nos } \\
\text { mercados internacionais. }\end{array}$ & MT \\
\hline
\end{tabular}




\subsubsection{A confusão de funções: diversas funções, diversas medidas}

A aparente simplicidade do termo "moeda internacional" e a focalização imediata na elucidação de quais as fronteiras que são ultrapassadas encobrem a complexidade do objeto central analisado. Compreender o que é moeda e como a moeda interfere nas interações entre agentes econômicos acompanha historicamente a reflexão econômica. Desde a antiguidade (SOUDEK, 1952) e passando pelos primórdios da consolidação da ciência econômica contemporânea a partir de Smith (1776, ch 4), persistem questões na compreensão da moeda e na representação de suas funções (OSTROY; STARR, 1990).

Não nos aprofundaremos nestas discussões, que transcendem em muito o escopo deste artigo. Partiremos, assim como as demais discussões sobre moedas internacionais, das três funções clássicas atribuída à moeda: meio de troca, reserva de valor e unidade de conta. O reconhecimento da existência de distintas funções para a moeda já permite explicar a sobreposição de termos que tentam posicionar uma moeda no cenário internacional.

Na tabela 2, apresentam-se os papéis exercidos internacionalmente pela moeda de acordo com suas funções tradicionais e com a natureza dos agentes - se privados ou estatais. Relacionamos na coluna de direita alguns termos que são usualmente associados a estas funções e constantemente se embaraçam com o conceito de moeda internacional

Tabela 2 - Papéis internacionais de uma moeda

\begin{tabular}{|c|c|c|c|}
\hline $\begin{array}{l}\text { Função } \\
\text { da moeda }\end{array}$ & $\begin{array}{l}\text { Natureza } \\
\text { dos agentes }\end{array}$ & Empregos da moeda no cenário internacional & Termos associados \\
\hline \multirow{2}{*}{ Meio de troca } & Privado & Faturar o comércio e transações financeiras & \multirow[t]{3}{*}{ moeda veículo } \\
\hline & Governo & Liquidação de saldos soberanos; Emissão de dívida soberana & \\
\hline \multirow{2}{*}{ Reserva de valor } & Privado & Substituição monetária ("dolarização" privada) & \\
\hline & Governo & Reservas internacionais & \multirow{3}{*}{$\begin{array}{l}\text { moeda reserva } \\
\text { moeda de faturamento } \\
\text { âncora cambial }\end{array}$} \\
\hline \multirow{2}{*}{ Unidade de conta } & Privado & Denominar o comércio e transações diversas & \\
\hline & Governo & Âncora cambial para a moeda local & \\
\hline
\end{tabular}

Nota: Elaboração do autor. Funções da moeda adaptadas de Frankel (2012).

\subsubsection{A confusão internacional}

Uma primeira reflexão trazida pelo termo moeda internacional é que algumas características fazem uma moeda ser mais que "nacional" . Nacional, por sua vez, é uma expressão diretamente relacionada à nação a à ideia de uma comunidade local comumente sob um governo soberano. Daqui por diante, nós utilizaremos nação, país e estado soberano indistintamente. Como as atuais moedas fiduciárias estão relacionadas a estados emissores - o que discutiremos em seguida-, nossa principal referência está concentrada nas características de um estado soberano, mas nós nos referimos a isto como um país, um termo muito mais usual em economia.

Em contraste com o termo "nacional", ao utilizarmos o termo "internacional" como 
qualificador estamos mais preocupados com circunstâncias que fazem uma moeda ser utilizada sem os limites usuais de uma economia fechada do que com o contrastaste com o significado de "moeda nacional" e a ligação existente entre uma nação e uma moeda. Costumeiramente, a hipótese primitiva de que uma moeda é emitida por um país surge naturalmente. Não obstante a sua naturalidade, a não observância de que este relacionamento biunívoco é uma hipótese assumida tem impactos relevantes sobre as conclusões econômicas derivadas porque todas as análises subsequentes são condicionadas a esta consideração.

\subsubsection{O relacionamento entre moeda e país}

Quando buscamos refletir sobre uma moeda em particular, nossas reflexões são levadas quase imediatamente a conectar esta moeda e um país em particular. A instintividade deste relacionamento biunívoco para o qual chamamos atenção parece natural, já que tradicionalmente a moeda tem sido um símbolo das nações nos últimos séculos passados (COHEN, 2000a, ch 2). No plano individual, Helleiner (1998) destaca que a expressão deste relacionamento se manifesta como uma expressão de nacionalidade. No plano estatal, a independência de um país em termos monetários tem sido percebida como uma manifestação relevante da soberania de uma país (SONO, 2003).

Entretanto, mesmo que a relação entre países e moedas possa ser forte, ela não é uma verdade absoluta ou definitiva. Uma moeda pode ser utilizada por mais de um país. O euro é um exemplo atual e tem sido frequentemente estudado na literatura recente. Sua configuração é conhecida como uma união monetária, obtida quando um conjunto de países usa uma moeda única, que é emitida por uma autoridade monetária comum. Além disso, um país pode utilizar mais de uma moeda. Cuba é um exemplo de um sistema em que uma mesma autoridade monetária nacional emite duas diferentes moedas coexistentes: o peso (CUP) e o peso conversível (CUC). Ambas são emitidas pelo banco central cubano e têm seu próprio conjunto de notas, que são uma expressão concreta da moeda. Ainda assim, um país pode não emitir nenhuma moeda. Pode adotar um moeda que não é de sua emissão própria, como o caso do Equador que adota o dólar americano como moeda local. Embora ainda cunhem algumas moedas, isto não é uma emissão, visto que é completamente lastreada na divisa estrangeira. Além disso, algumas instituições privadas podem emitir obrigações que desempenham funções da moeda. Como observamos, não há uma relação a priori entre moeda e estado.

Os primeiros sinais da associação entre dinheiro e um ente soberano são observados no início do século VI a.c., nos estágios iniciais do monopólio estatal sobre a cunhagem. A partir desta época, pode-se observar uma maior uniformidade física das moedas cunhadas (STEIL; HINDS, 2009, 872). A homogeneidade na cunhagem facilitava que os agentes 
comercializassem sob uma referência de valor confiável; assim, a cunhagem estatal representava a introdução de um conveniente instrumento nas relações econômicas naquela época.

Se houve um tempo em que a padronização de peças de metal eram uma preocupação principal, na sociedade da informação contemporânea, a credibilidade nos dados financeiros registrados e a não ocorrência de má gestão da unidade monetária de referência com propósitos políticos parecem se tornar preocupações mais destacadas. Governos foram certificadores confiáveis para moedas que eram negociadas por mercadores. Mas, num mundo com empresas globais como atores internacionais, os governos não são mais a única instituição passível de atuar como certificador global. Não parece ser improvável que os agentes possam revisar suas crenças em que governos são mais críveis que empresas, considerando ambos em um mesmo nível de responsabilidade, transparência e previsibilidade.

Certamente alguém poderia argumentar que empresas somente são responsabilizadas em decorrência do poder estatal de regulação e sanção. Não parece ser este o caso no entanto. No comércio internacional, por exemplo, a arbitragem privada tem um papel principal na solução de controvérsias (CASELLA, 1992), tendo a coação estatal apenas uma participação secundária (LEESON, 2008). A coação ao cumprimento de um determinado comportamento também decorre do comportamento dos demais agentes e da possibilidade de nunca vir novamente a negociar com eles. Embora nosso foco seja em moedas internacionais emitidas por países e seu status nas considerações que faremos daqui por diante, a relação direta entre moeda e um estado emissor não se mostra definitivamente como uma verdade incondicional. Ela é uma certeza dos tempos atuais que é instável ao longo do tempo.

\subsubsection{Inter-nacional: uma economia de estados}

A discussão de por que algumas mercadorias servem como meio de trocas na economia enquanto outras não servem tem acompanhado as discussões sobre o papel da moeda na economia desde seu começo (MENGER, 1892). Quando o debate é levado do campo das moedas para o campo das moedas internacionais, a discussão segue por um caminho diferente. Exceto pela investigação na escolha da moeda de faturamento no comércio internacional, as considerações sobre o cenário internacional focam primeiramente nas decisões dos governos. Algumas destas discussões podem ser exemplificadas como: se um país deve adotar um câmbio fixo ou flutuante; como deve um país gerenciar sua taxa de câmbio; se um país deve impor restrições ao fluxo internacional de capitais; a gestão de dívidas soberanas; a implementação e o gerenciamento de uniões monetárias entre os países. 
Em todas estas questões, os estados têm um papel central, atuando como uma unidade econômica fundamental. Ainda que os indivíduos sejam levados em conta, é o estado que é a unidade que desempenha o papel principal, podendo realizar escolhas independentes (soberanas). O raciocínio dominante é baseado em economias inicialmente fechadas que se abrem ao mundo em um momento posterior. Desta forma, o relacionamento entre países e moedas é trazido a um nível quase natural. Enquanto as discussões focadas em estados nacionais permanecem na economia internacional, a questão sobre por que um agente aceitaria uma moeda em lugar de uma outra parece ser mantida em segundo plano. O forte relacionamento existente entre uma moeda e um estado segue então um pressuposto corriqueiro em economia: de que o estado é a unidade principal quando consideradas as interações entre agentes no plano internacional.

Este papel principal desempenhado pelos países se torna claro quando observamos como os principais textos introdutórios apresentam o ambiente internacional em economia. Kenen (2000) introduz a economia internacional discutindo o conceito de se ter o país como a unidade econômica. Krugman, Obstfeld e Melitz (2012, 3), em seu texto para a graduação, definem que "o assunto da economia internacional [..] consiste das questões levantadas pelos problemas particulares da interação econômica entre estados soberanos" . Salvatore $(2009,13)$ recorre à "interdependência econômica e financeira entre nações" para destacar o debate da economia internacional. A "relação entre nações" , a relação "entre uma nação e o resto do mundo" e o "bem-estar de um país" são os assuntos que seriam os principais temas. Pugel (2011) recorre à soberania para caracterizar a existência de uma natureza especial relacionada à economia internacional. Atualmente, desde os mais primários contatos com os assuntos econômicos internacionais, o raciocínio econômico é desenhado para considerar os estados como sua unidade natural.

Feenstra $(2011,397)$ destaca a questão para a qual trazemos atenção quando faz sua introdução ao raciocínio internacional em economia. Ele argumenta que a "economia global surge apenas quando as interconexões entre os países são inteiramente consideradas" . A economia internacional é então pensada a partir da união de economias autocontidas, que, pelo menos, se aproximam do que entendemos por países. Economias que comercializam entre si são, portanto, um segundo estágio a partir de economias autocontidas. Contrariamente a esta visão, nós não apoiamos a ideia que a economia global surge a partir da interconexão entre países. Em sentido oposto, entendemos que a economia global é restringida pelas desconexões causadas pelos países. Assim, a decisão de política tomada por um estado no tradicional binômio moeda-país em nada se distingue de outras distorções introduzidas pelos estados na economia.

Uma crítica comum a este argumento que apoiamos é que, mesmo que estados soberanos sejam mencionados nos textos que referenciamos, os estudos de economias abertas 
é suficientemente conceitual e países são apenas a representação de uma economia abstrata. De acordo com este argumento, a teoria econômica é desenvolvida primordialmente de acordo com a lógica de uma economia (um mercado) e esta economia não é necessariamente correspondente a um estado soberano. Entretanto, mesmo que se abstraiam em relação aos estados soberanos, estas economias conceituais são unidades econômicas similares a países. Elas são entendidas como independentes do poder normativo das demais unidades e são capazes de se autorregularem independentemente. Elas são ainda unidades soberanas. Inicialmente, elas são independentes; em seguida, elas interagem com outras unidades igualmente independentes. O campo internacional é, no final das contas, entendido como uma questão de se cruzar fronteiras (APPLEYARD; FIELD, 2013).

A abordagem que seguimos mantém o indivíduo como a principal unidade econômica. No entanto, não o considera como sendo naturalmente contido por uma unidade econômica superior - um país, por exemplo. Esta não se trata da mesma abordagem ao incorporarmos microfundamentações à macroecnomia. Quando recorremos a agentes individuais em macroeconomia, eles são geralmente elementos de alguma unidade econômica ou similar.

Aqui consideramos que, em um primeiro momento, os indivíduos existem e pertencem a um mundo irrestrito - ao conjunto universo. Posteriormente, grupos de indivíduos são restringidos em suas interações de acordo com regras não-econômicas: países. Neste sentido, a interpretação vai além da consideração de micro agentes, mas considera o ambiente de países como uma restrição. O pertencimento a um país, o que parece ser quase natural para a atual civilização ocidental, restringe o indivíduo em muitas dimensões. Uma dimensão destas restrições está na limitação de interações econômicas.

Um agente, uma família, uma país, uma região: como escolhemos o agrupamento unitário que definimos como referência? A escolha de um país na economia internacional nada mais é do que uma opção arbitrária baseada no presente arranjo de estados nacionais.

Assim como o estado soberano tem atualmente um papel principal na economia internacional, o mesmo acontece à relação entre o estado soberano e a moeda. O dinheiro é, entretanto, uma busca dos agentes por uma referência em valor. Os estados não são uma solução natural para a delegação do poder de se escolher a referência; são apenas a opção corrente e comum. "Não há nada especialmente pitoresco em relação a uma economia que não tenha sua própria moeda" (FISCHER, 1982). Um país ter sua própria moeda é uma decisão política. 


\subsection{5 Áreas monetárias e o território dos países em economia}

Mesmo que o estado tenha um papel central no pensamento econômico, debates em relação à coincidência do território da autoridade monetária que emite uma moeda e do território de um país não são uma nova questão. No âmbito do debate sobre a adoção de taxas de câmbio fixas ou flutuantes, a teoria de áreas monetárias ótimas (AMO) surgiu com o questionamento se as fronteiras nacionais seriam o limite ótimo para a área de emissão de uma moeda. A ideia de que as fronteiras de um país geravam condições especiais na configuração de uma área monetária já era presente (LERNER, 1944, 375) quando foi impulsionada pela abordagem de Mundell (1961) à questão das taxa de câmbio, a qual ele tratou como uma tentativa de se desenhar fronteiras ótimas a áreas geográficas que compartilhariam as mesmas fronteiras. No artigo seminal de Mundell (1961), o leste norte-americano e o leste canadense seriam uma ilustração de uma região monetária (E), assim como o oeste norte-americano e o oeste canadense ilustrariam outra (W). Com características econômicas internas similares, as duas regiões, E e W, poderiam evitar desemprego e pressões inflacionárias com uma taxa de câmbio flexível entre elas e com uma taxa de câmbio fixa entre suas partes (americana e canadense). Contrariamente, com o leste e oeste de cada país juntos em uma mesma área monetária não seria possível evitá-los pela via monetária. A autoridade monetária nacional não é capaz de evitar desemprego e inflação com a mesma decisão de política monetária. As áreas monetárias propostas em Mundell (1961) não estavam restritas pelas fronteiras nacionais: um país utilizaria duas moedas distintas e, ao mesmo tempo, um moeda seria utilizada por dois diferentes países. Portanto, o território monetário não coincidia com o território do estado soberano.

Ainda que buscasse um domínio territorial ótimo, a discussão de Mundell sempre se deu a partir de um ponto de vista em que os governos nacionais teriam de acordar nas fronteiras das áreas monetárias. Em suas palavras, "no mundo real, [...] moedas são a principal expressão da soberania nacional" (MUNDELL, 1961, 661). Nesta perspectiva, moedas e fronteiras nacionais não coincidiriam, mas o território monetário continuaria como sendo uma questão de soberania.

As abordagens posteriores à questão das AMO reduziram a liberdade de discutir fronteiras de regiões, ainda que por vezes destacassem a dissociação entre os conceitos geográfios e econômicos apontados por Mundell. A discussão nas décadas de 1960 e 1970 seguiram investigando a abertura de uma unidade econômica (MCKINNON, 1963) e a variedade da cesta de produtos dentro de um país (KENEN, 1969). Daí por diante, a cada nova contribuição, o debate entre a adequação de taxas de câmbio fixas e taxas de câmbio flutuantes absorveu toda a atenção enquanto o interesse pelo domínio apropriado para uma moeda diminuiu, "desviando-se da discussão inicial", como registrou Ishiyama (1975, $334-5)$. 
O reaparecimento do argumento das AMO aconteceu na década de 1990. A implementação do euro reintroduziu energia na discussão de AMO (TAVLAS, 1993), após a reunificação alemã de 1990 tê-la revivido (GRAUWE, 1992). Desta forma, entretanto, os debates começaram a partir da realidade europeia e foram desenhados segundo as curiosidades daquela época. A transferência de autoridade nos assuntos monetários de um país para um ente supranacional tomou o centro das atenções. Vantagens e desvantagens de países europeus estabelecerem uma AMO comum ou um país pertencer ou não a esta união monetária europeia foram as principais perguntas. A condição nacional não sofreu alteração nas análises seguintes, ainda que a questão central analisada tenha sido alterada: a avaliação da implementação da zona do euro na década seguinte e a crise do euro na década posterior, quando os limites da integração, e em especial da coincidência das áreas monetária e fiscal, atraíram o interesse (KRUGMAN, 2013), (EICHENGREEN, 2014).

\subsubsection{Moedas supranacionais e internacionais}

Imprecisão adicional ao relacionamento entre o território de moeda e de países e também ao termo moeda internacional derivam das discussões supranacionais na Europa. Como mencionado na introdução, ao lidar com o euro, Moss (2011) argumenta que a residência na zona do euro é o critério para ser aplicado ao significado de nacional. Argumentamos, entretanto, que a zona do euro não se trata de um caso especial. Residênciaou mais precisamente a condição de um agente ser obrigado a seguir a normatização de algum órgão governante - deve ser o critério aplicado para distinguir entre as regiões internas e externas de alcance de uma moeda.

Ser uma moeda cuja área de emissão não coincide com o território de um país e, ao mesmo tempo, uma moeda amplamente utilizada no mundo torna difícil a imediata precepção da diferença entre esses dois conceitos a partir do exemplo do euro. O euro é uma moeda supranacional no sentido que um grupo de países acordaram a concessão de sua dita soberania monetária a uma autoridade monetária comum - o Banco Central Europeu - e o euro é também uma moeda amplamente aceita pelos agentes ao redor do mundo. $\mathrm{O}$ número dos países que emitem a moeda não influencia o nível de internacionalidade da moeda, mas define os domínios daquilo que se considera nacional e, seu complementar, internacional.

Esta diferença se torna mais evidente quando observamos exemplos como o franco CFA da África Ocidental (XOF) e o franco CFA da África Central (XAF). Ambas são moedas supranacionais. Benin, Burkina Faso, Costa do Marfim, Guiné-Bissau, Mali, Níger, Senegal e Togo transferem a autoridade de emitir moeda para o Banco Central da África Ocidental assim como Camarões, República Centro-Africana, Chade, Guiné-Equatorial, 
Gabão e República do Congo transferem-na para o Banco Central dos Estados Africanos. Apesar de serem supranacionais, estas não são moedas internacionais. Estas moedas são dificilmente aceitas fora de suas áreas de emissão, pois agentes não-residentes não reconhecem que elas desempenhem as funções da moeda para eles.

Para as discussões sobre moedas, a condição mais relevante para definir o conceito de nacional é o domínio em que os agentes estão sujeitos à normatização de uma autoridade monetária específica. Em outras palavras, a moeda pode ser associada à autoridade emissora ao invés de ser associada ao país, ideia expressa por Mundell (1961, 658) como "uma moeda implica um banco central". Neste arcabouço, internacional é, por extensão, o conjunto complementar. Internacional é o domínio que não está sujeito à autoridade monetária que emite a moeda em questão.

\subsubsection{O espaço sujeito a regulamentação}

Podemos aplicar o termo jurisdição monetária ao domínio sobre o qual uma instituição tem autoridade em questões monetárias. Um inconveniente do uso deste termo é ele possuir, em inglês, um sentido adicional nas ciências jurídicas. Entretanto, qualquer dúvida é dirimida pelo contexto de emprego do termo. Adicionalmente, a proposta de utilização deste termo não é nova e já foi aplicada com este sentido tanto na literatura econômica como jurídica. Como exemplo, temos o emprego do termo jurisdição monetária consonante ao mencionado em Padoa-Schioppa (1999, 296); em Teixeira e Schinasi (2006, 8); e em Hahn (1991, 784).

Apresentamos esta discussão sobre o emprego do termo em razão de o conceito de jurisdição monetária nos ajudar a destacar a questão central de um agente estar sujeito ou não à regulação de uma entidade emissora da moeda. Neste sentido, dizemos "internacional" para qualificar o domínio - territorial ou de agentes - o qual não está submetido ao poder regulador da autoridade monetária da moeda de referência. Ou seja, dizemos "internacional" aqueles agentes não sujeitos à jurisdição monetária, enquanto dizemos "domésticos" , "locais" ou "residentes" os agentes que estão sob a jurisdição monetária da autoridade emissora da moeda. Estão, desta forma, sujeitos ao poder de regular da autoridade emissora e da imposição de sua vontade em assuntos relacionados à moeda - sendo esta uma manifestação de soberania interna. O termo "nacional" - que seria a oposição esperada ao conceito de "internacional" — está mais fortemente atrelado à associação entre uma moeda e um país emissor do que em relação ao domínio sujeito à regulação.

Até aqui, discutimos a jurisdição monetária como sendo limitada por um critério de fronteiras geográficas. Devemos observar, no entanto, que o conceito de jurisdição para 
uma moeda está mais próximo de uma jurisdição abstrata do que tangível, em que um agente é ou não sujeito ao poder regulador da autoridade monetária, independentemente da sua localização geográfica.

\subsubsection{Nossa formulação}

Após discutirmos independentemente cada questão, vamos nos focar na consolidação das definições apresentadas. Como destacado anteriormente, devemos distinguir a característica e o status de uma moeda internacional. Internacionalidade é proposta como uma propriedade da moeda, enquanto a interpretação de uma moeda internacional como status é sustentada a partir da condição de uma moeda apresentar um determinado nível de internacionalidade. Nós não nos concentramos na tentativa de definir um nível que conferiria a uma moeda o status de ser internacional. Neste trabalho, é-nos suficiente perceber que o status de moeda internacional pode acontecer tanto em apenas uma função da moeda como em todas elas. Atualmente, o dólar americano ocupa a condição de exemplo típico para o status de moeda internacional em todas as dimensões possíveis; ocupando o topo da pirâmide monetária de Cohen (2012). No entanto, dependendo da questão avaliada, diferentes limites podem ser estabelecidos para concluir se uma moeda é ou não internacional, fazendo o conjunto das moedas que são consideradas internacionais variar. Se uma pirâmide é uma boa representação para o regime internacional de moedas, as moedas no topo dela compartilham um mesmo vértice que representa que estas moedas são reconhecidas como tal por todas as possíveis funções da moeda, enquanto as demais moedas podem estar diferentemente distribuídas ao longo da vertical de cada face da pirâmide, representando as diferentes dimensões da internacionalidade. Definitivamente, a representação unidimensional não reflete as diferentes denotações de status internacional de uma moeda.

A existência de diferentes dimensões para avaliar o status de uma moeda ilustra que a internacionalidade é uma propriedade multidimensional. A percepção de cada agente sobre a moeda pode ser diferente em relação a cada uma das funções da moeda, de modo que o reconhecimento que lhe é conferido pode ser diferente de acordo com cada função da moeda, variando de agente para agente.

São os agentes econômicos que conferem reconhecimento às moedas, mas a internacionalidade vem do reconhecimento conferido por aqueles agentes que não são induzidos a utilizarem a moeda em decorrência de algum poder estatal de obrigar agentes (poder de regulação interno). Então, a autoridade emissora da moeda é um ator principal em nosso arcabouço. O poder de uma autoridade monetária de constranger agentes (indivíduos e firmas) ao uso de uma determinada moeda os divide em dois subconjuntos complementares de agentes: aquele em que a autoridade tem poder regulatório sobre os agentes e aquele 
em que ela não o tem. É o uso pelos agentes no conjunto que não está sujeito à imposição governamental que confere a propriedade de internacionalidade a uma moeda.

Devemos observar, no entanto, que estes conjuntos não são necessariamente equivalentes a territórios geográficos ou obrigatoriamente com fronteiras nacionais. Ainda que sejam hipóteses usuais, as relações país-moeda e país-economia podem ser alteradas ao longo dos tempos. Tomar a globalização como o arranjo de comunidades supranacionais questiona este status quo internacional. Termos econômicos e a literatura econômica devem ser suficientemente consistentes e amplos a fim de acomodar e representar estes novos desafios e estas mudanças.

Retornamos então à definição do termo internacionalidade para consolidar as características apresentadas. Internacionalidade combina estas características como a propriedade de uma moeda de ter suas funções da moeda reconhecidas além do domínio que está sujeito ao jugo da sua autoridade monetária emissora. Moedas internacionais são então as moedas com suficiente nível de internacionalidade, nível este que é definido de acordo com critérios que variam de autor para autor.

\subsection{Comentários finais}

Neste ensaio, buscamos consolidar a estrutura conceitual em que uma moeda pode ser compreendida no cenário internacional. Definimos o termo internacionalidade como a propriedade de uma moeda ser internacional. Retiramos, assim, uma primeira ambiguidade do termo, que comumente também é empregado para representar o status de uma moeda no cenário internacional, o que, segundo nossa formulação, pode ser representado por uma moeda apresentar um nível de internacionalidade maior que algum determinado valor.

Destacamos que a internacionalidade de uma moeda se manifesta em disversas dimensões, as quais se confundem com as diversas funções que uma moeda pode exercer. Em seguida, dividimos os agentes econômicos em dois grupos: aqueles que estão sujeitos à regulamentação da autoridade emissora da moeda e aqueles que não estão sujeitos a ela. Assim, dissociamos a jurisdição monetária do território estatal, conferindo precisão ao corriqueiro termo internacional. Isto nos permitiu especificar cada dimensão da internacionalidade como a percepção dos agentes internacionais de uma moeda lhes exercer uma determinada função, consagrando-se portanto como moeda para eles.

Assim, lidamos com o problema do uso não padronizado e da imprecisão do termo moeda internacional, contribuindo para desfazer esta recorrente questão. 
Parte II

Ensaio 2 


\section{A moeda de faturamento do comércio ex- terior brasileiro}

\subsection{Introdução}

Quaisquer discussões relacionadas ao papel internacional do real (BRL) sofrem constantemente de uma mesma dificuldade: o questionamento preliminar de se resta ao BRL algum papel. Aqui, nós respondemos definitivamente esta questão, permitindo que os debates brasileiros em comércio internacional e utilização de moedas possa ir adiante. Partindo de uma definição em que uma moeda internacional é aquela utilizada além das fronteiras do país emissor, nós registramos que existem agentes que utilizam a moeda brasileira para faturar as operações de comércio exterior.

Nós registramos, pela primeira vez, a descrição do comércio brasileiro de acordo com a moeda que é utilizada para o seu faturamento. Utilizamos a série de 2007 a 2011 da base de dados organizada pelo Ministério do Desenvolvimento, Indústria e Comércio Exterior Brasileiro (MDIC). Nossa análise nos permite propor novas questões para a integração econômica do Brasil-políticas e analíticas-, enquanto algumas evidências que encontramos divergem de alguns resultados e previsões anteriores registrados na literatura. Deste modo, este estudo preenche uma lacuna nas considerações acerca da economia brasileira e sobre o uso do BRL, além de contribuir com novas evidências para a discussão sobre a utilização internacional das moedas.

A compreensão do papel desempenhado internacionalmente por uma moeda tem relevantes implicações de política. Pesquisadores têm discutido o papel internacional de uma moeda em um amplo espectro: desde a capacidade de obrigar outras economias (KIRSHNER, 1995; ANDREWS, 2006a) à incapacidade de acesso a mercados internacionais (EICHENGREEN; HAUSMANN; PANIZZA, 2005; HAUSMANN; PANIZZA, 2011). Aqui, lidamos com o papel internacional de uma moeda como unidade para a definição de preços do comércio, o que está usualmente relacionado à efetividade das políticas macroeconômicas. A escolha da moeda de faturamento é uma das explicações apresentadas para a conexão entre a rigidez de preços e taxa de câmbio destacada por Obstfeld e Rogoff (1995) (BETTS; DEVEREUX, 1996; ENGEL; ROGERS, 2001; BACCHETTA; WINCOOP, 2005). Em relação ao Brasil, a transmissão da variação cambial para a economia local já chamou alguma atenção (BELAISCH, 2003; CORREA; MINELLA, 2010; NOGUEIRA; MORI; MARÇAL, 2013). O mesmo não pode ser dito sobre o faturamento em BRL contudo. 
A quase inexistência de discussões relativas a este tema pode ser explicada pela histórica fragilidade da economia brasileira, que pode ser observada nas inúmeras trocas de padrão monetário ocorridas, principalmente na década de 1980. De 1986 a 1993, o Brasil teve cinco diferentes moedas ${ }^{1}$. A adoção do real em 1994 é um marco das transformações econômicas ocorridas no Brasil, as quais permitem que hoje se amplie o escopo das discussões relacionadas à moeda do país.

As exportações em moeda nacional eram vedadas no Brasil até abril de $2007^{2}$. No ambiente anterior de escassez de divisas, as receitas de exportação haviam sido a principal fonte de sua obtenção e, portanto, a obrigatoriedade de recebimento em moeda estrangeira foi uma forma de lidar com esta questão. A alteração do ambiente econômico com a decorrente maior disponibilidade de moeda estrangeira permitiu a retirada desta vedação, em um contexto em que as demais barreiras a operações cambiais também foram eliminadas.

Aliada a esta mudança de política, uma outra política afetou o faturamento em BRL durante o período examinado. Em outubro de 2008, Brasil e Argentina lançaram um sistema de pagamentos bilateral, o Sistema de Pagamentos em Moeda Local (SML) que tornou disponível um instrumento financeiro para liquidar o comércio exterior nas moedas locais. Um requisito para a utilização do sistema é, entretanto, que as operações comerciais tenham sido faturadas na moeda do país exportador. Assim, comerciantes que desejam utilizar o sistema de pagamentos foram incentivados a faturar as exportações brasileiras em BR: ou importações brasileiras em pesos argentinos (ARS).

Por causa da história econômica brasileira, quase todas as exportações brasileiras são faturadas em dólares dos Estados Unidos (USD). A participação residual é faturada em outras moedas internacionais. No entanto, constata-se que o BRL é utilizado para faturar o comércio e que seu uso cresceu nove vezes em cinco anos. Nós descrevemos este crescimento para contribuir com a compreensão do real no cenário internacional e para entender o comportamento da moeda de faturamento a partir do ponto de vista de uma moeda não-internacional.

Depois de constatarmos que o BRL é escolhido voluntariamente para faturar algumas operações de comércio, damos um passo adiante em prover uma nova agenda de pesquisa para a moeda brasileira e reportamos achados interessantes advindos dos dados brasileiros, examinando alguns temas atuais em relação à moeda de faturamento. Notamos

1 As moedas brasileiras durante este período foram as seguintes: 1967-86, o cruzeiro novo, renomeado cruzeiro em 1970 (BRB); 1986-89, o cruzado (BRC); 1989-90, o cruzado novo (BRN); 1990-93, o cruzeiro (BRE); and 1993-94, o cruzeiro real (BRR) (Banco Central do Brasil, 2007).

2 Esta situação foi alterada pela Resolução n 12/2007 da Câmara de Comércio Exterior (Camex), publicada no Diário Oficial da União em 26 abril de 2007, que autorizou que o recebimento das exportações brasileiras pudesse ser realizado em reais. 
que a provisão do governo de um instrumento financeiro - o SML-impactou a moeda de faturamento escolhida. Estabelecer esta ligação aumenta a importância de avaliar os padrões de faturamento em reais e confirma a nossa afirmação de que, embora limitado, o papel desempenhado pela BRL no cenário internacional pode contribuir para respostas de um grande conjunto de questões. Ademais, observamos que ser um bem homogêneo não é suficiente para fazer com que seja faturado em uma moeda internacional: o açúcar e o tabaco foram os produtos mais exportados em BRL.Isto contradiz a expectativa habitual de os produtos homogêneos negociados em bolsa no mercado internacional que sejam faturados em uma moeda internacional (MCKINNON, 1979; KRUGMAN, 1980b) e aponta para a ocorrência de algum poder de barganha no faturamento (FRIBERG; WILANDER, 2008; ITO et al., 2012; GOLDBERG; TILLE, 2013). Nós também achamos que, no caso brasileiro, a moeda escolhida para faturar não é aquela escolhida para se efetuar o pagamento, como constantemente têm sido observado na literatura (FRIBERG; WILANDER, 2008; ITO et al., 2013; ZHANG, 2014).

Este artigo está dividido em seis seções. Na próxima seção nós revisamos brevemente as discussões em internacionalização da moeda e no uso de moedas veículo. Então, na seção 2.3, nós descrevemos os dados utilizados e nossa metodologia. A seção 2.4 descreve em que moedas o comércio brasileiro é faturado. Além da prevalência do dólar americano (USD), nós encontramos que outras moedas internacionais e a moeda local (BRL) são utilizadas. Encontramos ainda que, nas importações, uma pequena proporção do comércio também é faturado em outras moedas não-internacionais. Nesta seção, nós também ressaltamos que a participação do faturamento em BRL cresceu durante o período observado. A seção 2.5 trata com os dados referentes ao faturamento em BRL. Nós descrevemos os principais parceiros e os principais produtos faturados na moeda local. Nesta seção, destacamos que alguns resultados da análise de nossos dados contrastam com resultados anteriores da literatura (empíricos e teóricos). A seção 2.6 apresenta comentários finais.

\subsection{Internacionalização da moeda e moedas veículo}

A internacionalização de uma moeda é o processo pelo qual uma moeda nacional passa a apresentar as suas funções características em um nível que transcende os limites das fronteiras do seu país emissor ${ }^{3}$. Duas dessas funções são as de meio de troca e de unidade de conta que se relacionam, respectivamente nas transações de comércio internacional, à moeda que serve como contrapartida para o ativo comercializado e à moeda que serve para

3 Veja Kenen (2011) para uma definição de moeda internacional similar. Entretanto, ainda que o termo país seja utilizado ao longo deste artigo, nós o utilizamos não apenas para representar um único país como também um conjunto de países formando uma coalisão de países que objetiva emitir uma única moeda. Por exemplo, a zona do euro compreende quinze países que, por meio de uma autoridade monetária comum (o Banco Central Europeu), emite o euro. O euro é a moeda de curso forçado no território de todos estes países. 
denominar o valor de faturamento da operação. Embora a moeda utilizada no faturamento e no pagamento das operações de comércio exterior possa diferir, algumas pesquisas anteriores encontraram que elas normalmente coincidem(FRIBERG; WILANDER, 2008; ITO et al., 2013).

Seguindo estas considerações, temos a ocorrência do faturamento das exportações em uma moeda como um dos indicadores do seu grau de aceitação internacional ${ }^{4}$. Ao optar por faturar uma operação de compra e venda em uma determinada moeda, exportador e importador confirmam seu entendimento de esta moeda eleita ser aceita como unidade de conta para ambos e a confirmam como meio de troca.

Podemos então nos questionar qual será esta moeda escolhida. Observamos que a moeda eleita para o faturamento da operação poderá ser a moeda emitida pelo país do exportador, a emitida pelo país do importador ou uma terceira moeda, distinta de suas moedas nacionais, o que se passou a conhecer como moeda veículo (vehicle currency, no original em inglês). Neste estudo, utilizaremos o termo moeda de faturamento para identificar a moeda em que uma determinada operação foi faturada e seu valor denominado.

Três linhas de investigação sobre a escolha da moeda veículo são sintetizadas por Goldberg e Tille (2008). A primeira foca nas transações financeiras ao invés do comércio. Nela, os custos de transação decorrentes do uso de uma moeda são determinantes para a escolha da moeda na qual um agente fatura. Os custos de transação são associados principalmente à característica de liquidez da moeda nos mercados financeiros internacionais (SWOBODA, 1968; SWOBODA, 1969). A segunda linha se concentra em relacionar a escolha da moeda de faturamento de um determinado produto com características específicas da sua indústria. Agentes que comercializam produtos com características homogêneas e o fazem em mercados específicos têm uma maior propensão a elegerem uma moeda específica a qual lhes permita definir preços e transacionar sem a adição de custos (MCKINNON, 1979; KRUGMAN, 1980b). A terceira linha de investigação associa a escolha da moeda de faturamento com a previsibilidade macroeconômica desta moeda. Assim, um agente escolheria a moeda para faturar suas operações de forma a minimizar a volatilidade da sua receita esperada (Baron, 1976).

Além das razões que levam um agente optar pelo faturamento em uma determinada moeda, outras principais perguntas que podem ser realizadas a respeito de faturamento do comércio podem ser sintetizadas em: como a escolha da moeda de faturamento afeta a internacionalidade ${ }^{5}$ de uma moeda e como a internacionalidade de uma moeda impacta

4 Para uma discussão sobre as vantagens e desvantagem de se ter uma moeda internacional, veja, por exemplo, Papaioannou e Portes (2008), Frankel (2012), and (COHEN, 2012).

5 Por internacionalidade, entendemos a propriedade de uma moeda ter suas funções reconhecidas por agentes não residentes. 
a escolha dos agentes no faturamento de suas operações. É razoável supor que moedas internacionais tenham uma maior propensão a serem aceitas como moeda de faturamento entre duas partes, principalmente em decorrência do efeito de externalidades de rede Flandreau e Jobst (2009). Por outro lado, a aceitação de uma moeda internacionalmente é função de sua participação nos pagamentos do comércio internacional, como sintetiza $\mathrm{Wu}$, Pan e Wang (2010) ao investigarem condicionantes para o processo de internacionalização da moeda. Assim, a compreensão do papel internacional do real e de seu posicionamento no mundo está relacionada em parte à sua utilização no comércio exterior brasileiro, o que confirma a relevância de se conhecer o seu estado de utilização, objetivo deste trabalho.

A investigação do real como moeda de faturamento busca analisar o fenômeno do crescimento de aproximadamente nove vezes de sua participação com esta função nas exportações totais brasileiras no período entre 2007 e 2011 (de 0,13 a 1,25\%). Embora a participação da moeda brasileira no conjunto de operações faturadas no comércio exterior seja reduzida, o crescimento de sua participação observado neste período de cinco anos é expressivo.

\subsection{Dados e metodologia}

\subsubsection{Dados de comércio}

Foram analisados os dados relativos a exportações e a importações brasileiras disponíveis para o Ministério do Desenvolvimento, Indústria e Comércio Exterior (MDIC) no período de 2007 a 2011 em periodicidade mensal. O MDIC registra cada operação de exportação e de importação feita para e a partir do Brasil. Ambos os valores de exportações e importações são registrados por seu valor FOB $^{6}$ pelo MDIC. Os dados são obtidos do registro de exportação apresentado pelo exportador ao MDIC e da declaração de importação apresentada pelo importador à Receita Federal do Brasil (RFB). Os comerciantes declaram a moeda de faturamento e o valor faturado de cada operação. Estes valores declarados são convertidos para dólares americanos pela taxa de câmbio do dia e armazenados na base de dados.

Nós não pudemos obter dados detalhados por empresa, por isso não foi possível verificar, em particular, a hipótese de os registos em moeda local serem decorrentes de fatores contábeis internos à empresas multinacionais. As empresas com operações no Brasil e no exterior tem sua logística intrafirmas internacionais contabilizados como exportações

6 De acordo com o INCOTERMS 2010, o valor free on board (FOB) é aquele que considera o valor do bem sem a adição de valores relativos a seguro e frete. Ele se distingue do valor CIF, o qual considera o valor do bem adicionado dos custos de seguro e frete e é o método usual de se registrar importações de acordo com as estatísticas da Organização Mundial do Comércio(OMC). 
e importações como fossem diferentes empresas. No entanto, pode-se argumentar que o fator contábil superaria o fator comercial, de modo que o faturamento na moeda local seria decorrente do interesse de se evitar a volatilidade do câmbio no balaço empresarial e não decorrente de um escolha de moeda irrestrita. A indisponibilidade de dados detalhados por firma impede a verificação desta hipótese.

Os valores registrados no banco de dados de comércio brasileiro estão em moeda norte-americana. O uso desta moeda como a moeda registro é significativo. Ele mostra explicitamente como a economia doméstica depende de uma referência externa. Isto é semelhante à situação em outros países, como discutido mais adiante. No entanto, o Brasil é fortemente dependente do referencial em USD. Assim, embora o presente estudo seja focado no faturamento do comércio exterior brasileiro em BRL, todos os dados são apresentados em USD.

Dos dados obtidos, foram excluídas as observações relacionadas a provisão de embarcações e aeronaves, salvo quando mencionado em contrário. A apropriação das exportações nesta finalidade ocorre quando as exportações são realizadas no Brasil, a fim de atenderem necessidades de abastecimento de navios estrangeiros quando em trânsito em portos e aeroportos brasileiros. Estas despesas de consumo ocorrem em decorrência da necessidade de reabastecimento local, quando o consumo ocorre no território do país do vendedor. Estas características proporcionam um viés nas escolhas relacionadas à operação comercial e se distanciam dos objetivos do presente estudo. Tais exportações são de montante relevante, principalmente ao se observar transações na moeda brasileira. Em média representam 71\% do faturamento em BRL entre 2007-8 e 23\% de 2009-11. A não exclusão destes valores superestimaria a escolha do real como moeda de faturamento em situações em que o comprador não teria outra opção senão realizar aquisições na moeda local.

Em relação aos dados de importação, nós devemos ser particularmente cautelosos em relação à sua interpretação. A base de dados do MDIC registra como país de origem da mercadoria o país em que a mercadoria foi produzida; não a nacionalidade da empresa que realizou a venda (Ministério do Desenvolvimento, Indústria e Comércio Exterior, 2013). Assim, há mercadorias importadas que têm como origem o Brasil. Esta mercadoria foi primeiramente exportada para um país estrangeiro e depois exportada de volta para o Brasil, sendo registrada como uma importação brasileira de produto brasileiro. Estes dados foram excluídos das tabelas em razão de não proverem um explicação relevante para os produtos exportados faturados em BRL, que é o nosso objetivo aqui. Estas mercadorias não atingiram 0,05\% até 2009, mas apresentaram uma participação significativa em 2010 de 17,68\% e em 2011 de 8,65\%. A maior parte destes dados dos dois últimos anos estão relacionados a importação de trens: $12,56 \%$ e 5,03\% são relativos a estas operações. 
Nós assumimos que a diferença de inflação entre a moeda nacional e a moeda estrangeira é absorvida pela variação da taxa de câmbio entre as duas moedas. Adicionalmente, o deflacionamento pela inflação do USD (8,5\%) ou pela inflação do BRL $(24,6 \%)$ traria diferentes resultados relativos com pouca contribuição para o nosso trabalho ${ }^{7}$. Estudar o crescimento do uso do BRL com dados registrados em USD tem um escolha natural de qual unidade é utilizada como referência. Como a magnitude do crescimento do uso do BRL (960\%) é consideravelmente mais alta que as taxas de inflação (8,5\% e 24,5\%), nós não consideramos estas taxas como a única causa para o resultado geral. Então a volatilidade do câmbio durante o período substitui o deflacionamento da série e nós apresentamos os resultados em valores nominais correntes para cada anos. Nós discutimos a volatilidade da taxa de câmbio mais adiante neste artigo.

\subsubsection{Dados financeiros relacionados ao comécio}

Nós também utilizamos dois conjuntos de dados para identificar os pagamentos denominados em BRL e contrastar os valores de comércio e financeiros na subseção 2.5.3. O primeiro conjunto vem da base de dados de TIR do Banco Central do Brasil (BCB). Ela registra as ordens de pagamento entre um residente e um não-residente no Brasil em BRL, que são conhecidas como Transferências Internacionais de Reais (TIR). O mesmo período de dados da série de comércio exterior foi obtido, com detalhamento por operação realizada.

As instituições financeiras são obrigadas a comunicar todas as operações acima de BRL 10.000. Este é o mesmo limite a que um indivíduo está submetido para portar em dinheiro em uma entrada ou saída fronteiriça sem ter de reportá-la, de acordo com as normas contra a lavagem de dinheiro. Além disso, assumimos que as instituições financeiras fora do Brasil não oferecem serviços de forma significativa em BRL-caso ofereçam, a conta está disponível por meio de um banco correspondente, oferecendo uma conta mantida em realidade no Brasil. Assim, qualquer pagamento feito em BRL é assumido ser realizado no Brasil, o que significa que as instituições financeiras que prestam serviços de transferência de BRL estão sob a regulação do mercado brasileiro, tendo, assim, de registar estas operações no Banco Central do Brasil.

A segunda fonte de dados financeiros denominados em BRL são os dados do SML do BCB. A ordem de pagamento do SML é um outra opção para a liquidação internacional e se aplica somente ao comércio entre Brasil e Argentina. A ordem de pagamento do SML é uma remessa transfronteiriça de BRL do Brasil para a Argentina, que pode ser utilizada para recebimento do pagamento de exportações brasileiras. De acordo com a regulamentação

7 A inflação do USD corresponde à variação do Índice de Preços ao Consumidor dos Estados Unidos entre 2007 e 2011; e a inflação do BRL corresponde à variação do Índice Nacional de Preços ao Consumidor Amplo (IPCA) no mesmo período. 
estas exportações brasileiras devem ter sido faturadas na moeda nacional do exportador. Então, exportações brasileiras pagas em BRL por meio do SML correspondem a uma operação de valor equivalente de faturamento em BRL. O pagamento de importações brasileiras não é considerado para nossos propósitos por serem fixados em ARS, mesmo que o pagamento final ao importador seja feito em BRL. A série obtida tem início com o lançamento do sistema em outubro de 2008 e segue até o último ano dos dados da série de comércio exterior, com periodiciadade mensal.

\subsubsection{Definição de moeda internacional}

Ao longo desse artigo, nós consideramos uma moeda suficientemente usada no comércio internacional como uma moeda internacional, enquanto uma moeda não-internacional é uma cujo uso é limitado às fronteiras do país emissor.

Como referência, adotaremos como moedas conversíveis internacionalmente para o comércio internacional aquelas moeda disponíveis para utilização no Continuous Linked Settlement (CLS). O CLS é um sistema de compensação privado que disponibiliza a liquidação internacional de operações entre diferentes moedas. A opção, neste trabalho, por esta forma de identificação de moedas internacionais se justifica por sua conveniência. A resposta binária à questão de internacionalização de uma moeda simplifica substancialmente a avaliação das características de uma moeda em relação à percepção dos agentes no mundo, motivo pelo qual preferimos um indicador contínuo num espaço multidimensional de percepção dos diversos agentes sobre as características do padrão monetário. Contudo, a simplificação obtida pela resposta binária é suficiente para as considerações elaboradas no presente artigo e, portanto, justificamos esta opção aqui realizada. Neste sentido, no CLS, são dezessete moedas disponíveis para operação no sistema e, pelo volume de operações, podemos considerar que estas moedas são em determinado grau conversíveis internacionalmente ${ }^{8}$ (CLS GROUP, 2012).

\subsection{Moedas de faturamento no comércio exterior brasileiro}

Nesta seção, nós observamos a distribuição do uso de moedas no comércio exterior brasileiro. Aqui, nosso objetivo é mostrar quais moedas são utilizadas para faturamento

8 Para participar do CLS, uma moeda deve ser considerada suficientemente conversível. Por este motivo, utilizaremos esta percepção de mercado para considerar quais as moedas internacionalmente conversíveis neste estudo. Obviamente a participação no CLS está sujeita a critérios políticos em relação aos agentes envolvidos, como, exemplificadamente, a entrada da moeda estar sujeita à aprovação do Federal Reserve (Fed), o banco central norte-americano. Compreendemos esta questão como uma restrição não-econômica a participação de uma moeda no CLS, que está além dos objetivos de análise do presente estudo. Cientes desta questão, entendemos que a participação de uma moeda no CLS é suficiente para indicar que esta tem um grau elevado de internacionalização em razão da consideração de ser suficientemente conversível. 
no Brasil e destacar a ocorrência de faturamento em BRL. A percepção usual leva à ideia de que a moeda local não-internacional não é, em nenhuma ocasião, preferível a qualquer outra moeda, deixando nenhum espaço para a moeda brasileira desempenhar qualquer papel internacional. Independentemente do argumento utilizado para sustentar esta ideia - seja por isto ser consequência da possibilidade de os agentes usarem uma moeda global muito mais eficiente, seja por isto ser consequência de uma relação centro-periferia-, nós estabelecemos que a inexistência de um papel internacional não é verdadeira. Nós atestamos que o BRL é de fato utilizado voluntariamente para faturar o comércio e estabelecemos que ele desempenha algum papel internacional; pelo menos como unidade de conta para algum conjunto de agentes.

Como mencionado na seção 2.1, os exportadores brasileiros eram proibidos de receber seu pagamento na moeda local até 2007, o ano de início de nossa série. De 2007 a 2011, nós observamos que a distribuição das exportações brasileiras por moeda de faturamento é altamente concentrada. Onze moedas foram utilizadas para faturar, tendo o USD representado aproximadamente $95 \%$ do valor total das exportações. Todas as moedas utilizadas para faturar as exportações são moedas internacionais, exceto o BRL, que é a moeda local. Além do USD, o montante remanescente é faturado em euro (EUR) e residualmente nas outras nove moedas, que incluem o $B R L^{9}$. As colunas à esquerda na tabela 3 mostram um resumo desses dados.

Ao contrário do faturamento das exportações brasileiras, o faturamento das importações não ocorre exclusivamente em moedas internacionais ou em BRL. Embora a participação das moedas internacionais seja de 99,98 \% das importações, outras moedas nacionais não-internacionais também são identificadas, adicionalmente ao BRL. Os restantes $0,02 \%$ (cerca de USD 220 milhões) é distribuído entre um grande conjunto de moedas. Importadores brasileiros aceitam diferentes moedas para faturar operações de pequenos valores. Durante o período analisado, o número de moedas neste conjunto aumentou ligeiramente de 32 (em 2007) para 36 (em 2011). O lado direito da tabela 3 (importações) consolida os dados sobre moedas internacionais e a participação do BRL. A figura 1 explicita o crescimento do faturamento em BRL: nove vezes maior em um período de cinco anos nas exportações e quatro vezes maior nas importações.

Mesmo ainda sendo predominante no faturamento das importações brasileiras, o dólar tem uma participação menor: cerca de $85 \%$. Por outro lado, a participação das importações em EUR é duas vezes maior que a sua participação nas exportações. O EUR permaneceu estável em um nível de 11\%. O BRL é o terceiro, com crescimento de 0,5\%

9 As nove moedas adicionais são o BRL, a libra esterlina (GBP), o iene japonês (JPY), a coroa sueca (SEK), o dólar canadense (CAD), o dólar australiano (AUD), o franco suíço (CHF), a coroa norueguesa (NOK), e a coroa dinamarquesa (DKK). 
Tabela 3 - Participação da moeda no valor faturado nas exportações e importações brasileiras, por moeda, 2007-11 (\%)

\begin{tabular}{ll|rrrrr|rrrrrr}
\hline \multicolumn{1}{c|}{ Moeda } & \multicolumn{9}{c|}{ Exportações } & \multicolumn{5}{c}{ Importações } \\
& & 2007 & 2008 & 2009 & 2010 & 2011 & 2007 & 2008 & 2009 & 2010 & 2011 \\
\hline Dólar americano & USD & 94,7 & 94,4 & 93,8 & 94,3 & 94,5 & 85,5 & 85,7 & 83,2 & 83,6 & 83,8 \\
Euro & EUR & 4,76 & 4,95 & 4,51 & 4,28 & 3,80 & 11,1 & 10,7 & 12,2 & 11,6 & 11,3 \\
Real & BRL & 0,13 & 0,16 & 1,11 & 0,82 & 1,25 & 0,48 & 0,50 & 1,08 & 1,83 & 1,95 \\
Outras moedas internac. & 0,44 & 0,52 & 0,55 & 0,54 & 0,49 & 2,95 & 3,11 & 3,47 & 3,02 & 2,94 \\
\multicolumn{2}{l}{ Outras moedas } & - & - & - & - & - & 0,07 & 0,02 & 0,03 & 0,01 & 0,02 \\
\hline
\end{tabular}

Fonte: Ministério do Desenvolvimento, Indústria e Comércio Exterior - MDIC

Nota: Sinais convencionais utilizados: 0,0 : dado numérico resultante de arredondamento de um dados numérico originalmente positivo, -: dado numérico igual a zero, não resultante de arredondamento. As moedas representadas como "outras moedas internac." são: a libra esterlina (GBP), o iene japonês (JPY), a coroa sueca (SEK), o dólar canadense (CAD), o dólar australiano (AUD), o franco suíço (CHF), a coroa norueguesa (NOK), e a coroa dinamarquesa (DKK).

Figura 1 - Crescimento da participação das moedas (2007-11)

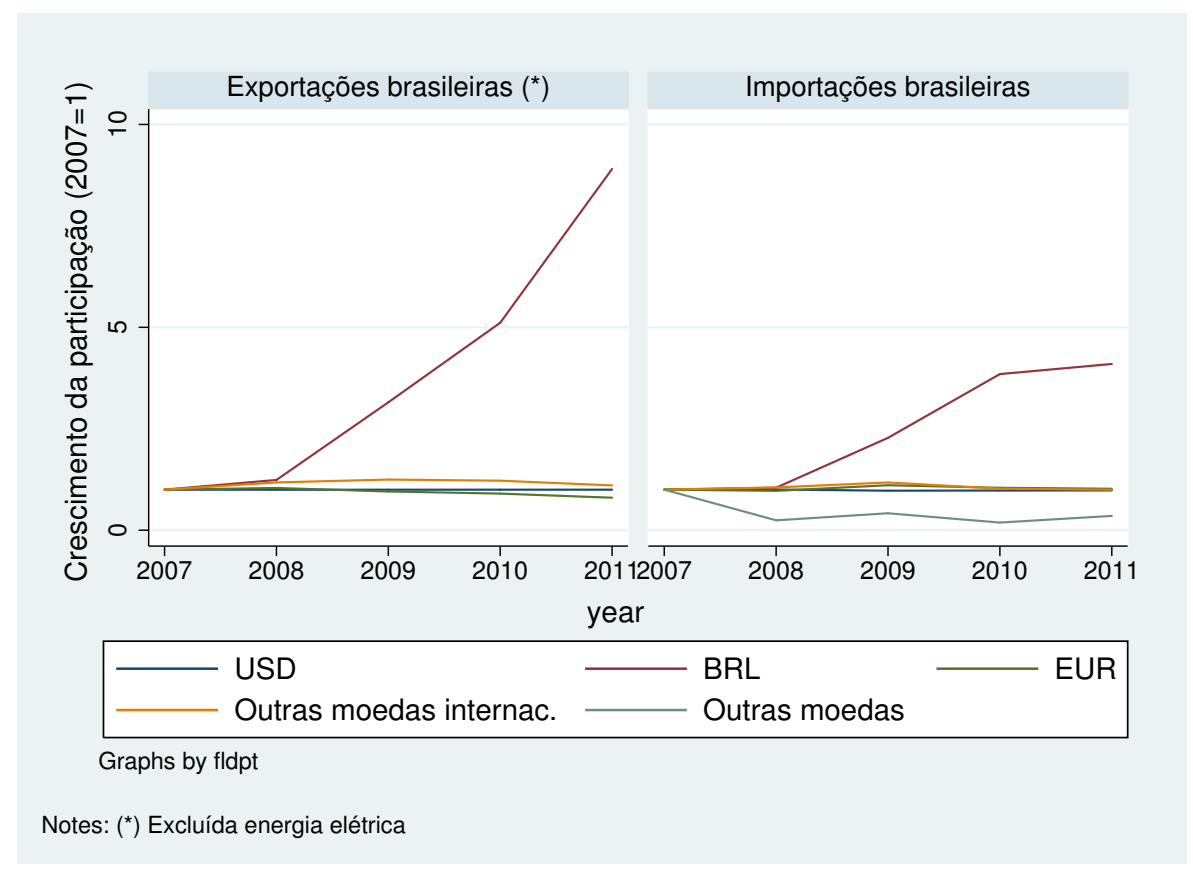

para quase $2 \%$ em 2011, a um nível semelhante ao JPY e acima do GBP. Ao comparar as exportações e importações faturadas em BRL, é claro que as importações em BRL experimentaram um crescimento menor. No entanto, a sua quota de 1,95\% é maior do que a quota de exportação de $1,25 \%$.

Uma questão a desafiar a conclusão de crescimento do uso do BRL pode ser a variação cambial. Conforme relatado na seção anterior, o comércio exterior do Brasil é registrado em USD. Assim, a variação na participação das outras moedas poderia ser atribuída a variação de sua taxa de câmbio contra o USD, usado como referência. Consequentemente, temos de ser cautelosos ao concluir que houve uma substituição do faturamento em uma moeda pelo faturamento em outra, apenas avaliando os dados de 
fluxo de comércio detalhado por moeda de faturamento da operação.

Figura 2 - Variação cambial do BRL e do EUR em relação ao USD (2007-11)

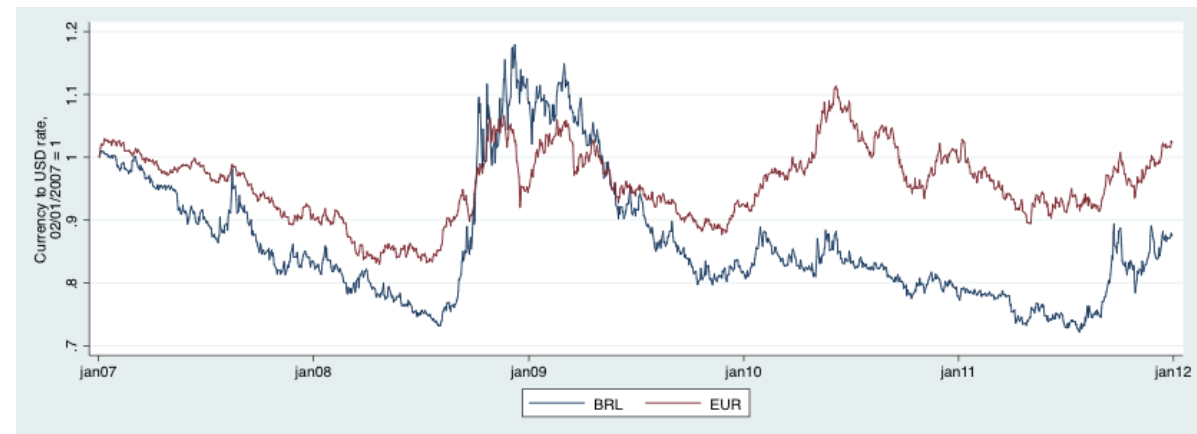

Fonte: Banco Central do Brasil - BCB

A figura 2 exibe tanto a variação do BRL como a do EUR contra o USD no período de 2007-2011, normalizados para o primeiro dia. Durante este período, o BRL seguiu uma tendência de valorização em relação ao dólar, fortemente revertida durante a intensificação da crise financeira internacional. O EUR seguiu uma tendência semelhante durante o período inicial em uma escala menor. Após o agravamento da crise, a apreciação EUR se enfraqueceu, e a diferença entre as taxas de câmbio do EUR e do BRL sugere algum impacto sobre a análise dos dados nominais do comércio brasileiro registados em USD.

Nós nos concentramos no aumento da participação do faturamento em BRL. Mesmo considerando a variação cambial no período, o aumento na participação do faturamento foi significativo para o BRL: as exportações cresceram de 0,13 \% para 1,25\%. A participação do faturamento em BRL foi nove vezes maior, enquanto a média anual da taxa de câmbio variou menos de 15\%. Em comparação com o nível de 2007, a média de fechamento diário foi $6 \%$ menor em 2008, $2 \%$ maior em 2009; 10\% menor em 2010, e 14\% menor em 2011. Conforme argumentado pela inflação, a variação da taxa de câmbio não é suficiente como a única explicação para o crescimento utilização BRL.

Enquanto a participação do USD no faturamento das exportações se manteve estável durante a série plotada na tabela 3, a participação do BRL aumentou significativamente, com a diminuição do EUR e da participação de outras moedas. Isto confirma a nossa curiosidade sobre o fenômeno de aumento da participação do BRL. O BRL foi usado como moeda de faturamento nas operações em 24 países diferentes em 2007; em 2011, o número de países de destino aumentou para 96 países.

\subsection{Panorama do comércio faturado em BRL}

A subseção seguinte lida com o uso do BRL. Após estabelecermos na última seção que o BRL é utilizado no comércio, aqui nós observamos o crescimento do BRL na subseção 
2.5.1. Na subseção 2.5.2, nós relatamos que este crescimento foi notavelmente significativo quando olhamos para o comércio brasileiro com a Argentina e sugerimos que o sistema de pagamentos bilateral implementadas pelos governos nacionais impulsionou a escolha da moeda de faturamento. Na subseção 2.5.2, destacamos que as principais exportações em BRL são produtos homogêneos e, na subsecção 2.5.3, nós testamos se a escolha da moeda de faturamento corresponde com a moeda escolhida para fazer os pagamentos.

\subsubsection{O faturamento em BRL se tornou mais comum}

Partimos da descrição do faturamento em BRL por país. A tabela 4 detalha as exportações faturadas em BRL. Esta tabela exibe todos os países cuja média de participação nas exportações totais faturadas em BRL entre 2007-11 foi maior que $1 \%$. A tabela 5 mostra o fluxo de importação.

Podemos constatar a existência de dois diferentes níveis de exportações faturadas em BRL, mas não podemos definitivamente afirmar uma tendência de crescimento por causa do curto período de avaliação. No entanto, é evidente que o faturamento em BRL ocorreu em um nível mais elevado no período 2010-11 do que em anos anteriores.

A tabela 4 lista os principais destinos de exportação, relacionando os países que apresentaram uma participação superior a $1 \%$ em faturamento em BRL nas exportações brasileiras na média dos dados da série. Existem três colunas para cada ano. A da esquerda mostra o valor total das exportações faturadas em BRL, em USD (milhões); a do meio mostra a participação do país no total do faturamento em BRL nas exportações brasileiras; e a da direita mostra a participação do faturamento em BRL no total das exportações para o país.

Mesmo que doze países estejam listados como principais destinos, os três parceiros comerciais do Mercosul (Argentina, Paraguai e Uruguai) representam mais de $85 \%$ das exportações faturadas em BRL no período entre 2007 e 2010 e mais de $53 \%$ em 2011. Os parceiros do Mercosul mostraram uma destacada liderança no faturamento em BRL no período inicial, e o faturamento nesta moeda se distribuiu nas exportações por demais parceiros no último passado. Esta difusão sugere que os exportadores brasileiros se tornaram mais propensos a usar a sua moeda nacional em faturamento. Enquanto apenas 24 países eram destinos das exportações faturadas em BRL em 2007, este número subiu para 96 países diferentes no último ano. Este aumentou foi gradual até 2010 (60 países), e se acentuou no ano seguinte.

Argentina e Paraguai são dois destaques na lista na tabela 4. O Paraguai liderou a tabela em 2007 e 2008, com mais de dois terços do total das exportações faturadas 
Tabela 4 - Exportações em reais para 12 principais países em valores, por país de destino (2007-11)

\begin{tabular}{|c|c|c|c|c|c|c|c|c|c|c|c|c|c|c|c|}
\hline \multirow[b]{2}{*}{ Destino de exportação } & \multicolumn{3}{|c|}{2007} & \multicolumn{3}{|c|}{2008} & \multicolumn{3}{|c|}{2009} & \multicolumn{3}{|c|}{2010} & \multicolumn{3}{|c|}{2011} \\
\hline & $\begin{array}{l}\text { Valor } \\
\text { USD M }\end{array}$ & $\begin{array}{l}\text { Ctr/TBE } \\
\%\end{array}$ & $\begin{array}{l}\mathrm{BRL} / \mathrm{TE} \\
\%\end{array}$ & $\begin{array}{l}\text { Valor } \\
\text { USD M }\end{array}$ & $\begin{array}{l}\mathrm{Ctr} / \mathrm{TBE} \\
\%\end{array}$ & $\begin{array}{l}\mathrm{BRL} / \mathrm{TE} \\
\%\end{array}$ & $\begin{array}{l}\text { Valor } \\
\text { USD M }\end{array}$ & $\begin{array}{l}\mathrm{Ctr} / \mathrm{TBE} \\
\%\end{array}$ & $\begin{array}{l}\mathrm{BRL} / \mathrm{TE} \\
\%\end{array}$ & $\begin{array}{l}\text { Valor } \\
\text { USD M }\end{array}$ & $\begin{array}{l}\text { Ctr/TBE } \\
\%\end{array}$ & $\begin{array}{l}\mathrm{BRL} / \mathrm{TE} \\
\%\end{array}$ & $\begin{array}{l}\text { Valor } \\
\text { USD M }\end{array}$ & $\begin{array}{l}\mathrm{Ctr} / \mathrm{TBE} \\
\%\end{array}$ & $\begin{array}{l}\mathrm{BRL} / \mathrm{TE} \\
\%\end{array}$ \\
\hline Argentina & 4,3 & 2,2 & 0,0 & 12,4 & 4,1 & 0,1 & 1.361 & 82 & 11 & 1.106 & 67,5 & 6,0 & 1.327 & 42,5 & 5,8 \\
\hline Paraguai & 151,7 & 75,3 & 9,2 & 216,7 & 71,0 & 8,7 & 187,5 & 11 & 11 & 249,4 & 15,2 & 9,8 & 261,4 & 8,4 & 8,8 \\
\hline Uruguai & 28,4 & 14,1 & 2,2 & 36,9 & 12,1 & 2,2 & 32,2 & 1,9 & 2,4 & 40,5 & 2,5 & 2,6 & 61,6 & 2,0 & $2, \S$ \\
\hline Bolívia & 5,8 & 2,9 & 0,7 & 25,7 & 8,4 & 2,3 & 17,4 & 1,0 & 1,9 & 18,7 & 1,1 & 1,6 & 71,4 & 2,3 & 4,7 \\
\hline Bélgica & - & - & - & 0,1 & 0,0 & 0,0 & 0,0 & 0,0 & 0,0 & 124,4 & 7,6 & 3,6 & 170,3 & 5,5 & 4,3 \\
\hline Estados Unidos & - & - & - & 3,8 & 1,2 & 0,0 & 17,5 & 1,1 & 0,1 & 27,8 & 1,7 & 0,1 & 197,1 & 6,3 & 0,8 \\
\hline Emir, Árabes U. & - & - & - & & & & 0,0 & 0,0 & 0,0 & & & & 126,9 & 4,1 & 5,8 \\
\hline Alemanha & - & - & - & 0,8 & 0,3 & 0,0 & 13 & 0,8 & 0,2 & 10,5 & 0,6 & 0,1 & 68,9 & 2,2 & 0,8 \\
\hline Países Baixos & 0,6 & 0,3 & 0,0 & 3,8 & 1,2 & 0,0 & 0,5 & 0,0 & 0,0 & 0,0 & 0,0 & 0,0 & 63,9 & 2,0 & 0,5 \\
\hline França & 6,1 & 3,0 & 0,2 & 0,0 & 0,0 & 0,0 & 0,1 & 0,0 & 0,0 & 0,0 & 0,0 & 0,0 & 4,1 & 0,1 & 0,1 \\
\hline R Unido & 0,1 & 0,0 & 0,0 & & & & 15 & 0,9 & 0,4 & 18,7 & 1,1 & 0,4 & 22,8 & 0,7 & 0,4 \\
\hline Canadá & - & & - & 0,0 & 0,0 & 0,0 & 2,6 & 0,2 & 0,2 & 4,5 & 0,3 & 0,2 & 71,5 & 2,3 & 2,3 \\
\hline
\end{tabular}

Ministério do Desenvolvimento, Indústria e Coné11 nototal das exportacões faturadas em BRL tenha ultrapassado 1\%. Cada ano é dividido em tês colunas: a coluna da esquerda (Valor) mostra o valor total exportado para o país em milhôes de USD; a coluna do meio (Ctr/TBE) mostra a participação do país nas exportações totais em BRL; a coluna da direita (BRL/TE) mostra a participação do faturamento em

BRL nas exportações totais para o país.
Sinais convencionais utilizados: 0,0 : dado numérico resultante de arredondamento de um dados numérico originalmente positivo, -: dado numérico igual a zero, não resultante de arredondamento 
em BRL. A Argentina substituiu o Paraguai nessa posição nos anos seguintes, tendo um máximo de $82 \%$ de participação em 2009. Mas isto não foi resultante de uma redução das exportações faturadas em BRL para o Paraguai, mas um forte aumento das exportações brasileiras faturadas em BRL para a Argentina. Considerando os valores deflacionados, as exportações em BRL para a Argentina aumentaram em mais de $28.000 \%$ entre 2007 e 2011, enquanto as para o Paraguai aumentaram em 59 \%. A subseção 2.5 .2 vai investigar mais a fundo o caso argentino.

Agora vamos contrastar os números de exportação com os valores das importações. A tabela 5 exibe $90 \%$ do montante total destas importações por país. Os dados são exibidos por ano em duas colunas. A coluna da esquerda mostra a quantidade total de importações faturadas em BRL da origem, em milhões de USD, e, na coluna da direita, mostra a participação das importações faturadas em BRL comparada ao total das importações brasileiras provenientes daquele país.

Como mostrado na tabela 3, a participação das importações em BRL é de $1.95 \%$ contra a participação nas exportações de 1,25\%. Como os destinos das exportações brasileiras, o número de países exportando em BRL cresceu gradualmente de 53 para 81 durante o período avaliado. Da mesma forma, o conjunto de países com o maior volume de importações faturadas em BRL é substancialmente diferente do daqueles conjunto em que se consideram as exportações faturadas em BRL.

A tabela 5 mostra que os países que mais exportaram faturando em BRL foram aqueles que têm moedas internacionais como moeda de curso legal. Entre os quinze maiores países exportadores em BRL, apenas três têm moedas não-internacionais: China, Coréia do Sul e Índia. Com efeito, os Estados Unidos foram o país que apresentou o segundo maior valor faturado em BRL. Quando o BRL, que é não-internacional, é contrastado com o USD, que é líder como a moeda de faturamento internacionalmente, há ocasiões em que o BRL foi escolhido, o que sugere que existem outras características além do uso internacional por demais agentes (ganhos de rede) como determinantes na escolha da moeda de faturamento.

Em relação à distribuição entre os países, as importações estão consideravelmente concentradas. Alemanha, Estados Unidos e China respondem por dois quintos do montante total. Os parceiros do Mercosul não apresentam a mesma participação nas importações como nas exportações. Argentina está na lista, mas seu total de USD 25 milhões em exportações faturadas em BRL está distante do valor de USD 1.250 milhões de produtos importados usando a moeda do país vizinho. O saldo de pagamentos bilateral não é tão negativo quanto o é quando observados apenas os valores faturados em BRL. As importações do Paraguai e do Uruguai não se observam propensas a serem faturadas em 
Tabela 5 - Principais origens de importações brasileiras faturadas em BRL, por país $(2007-11)$

\begin{tabular}{|c|c|c|c|c|c|c|c|c|c|c|}
\hline \multirow{3}{*}{ Origem da importação } & \multicolumn{2}{|c|}{2007} & \multicolumn{2}{|c|}{2008} & \multicolumn{2}{|c|}{2009} & \multicolumn{2}{|c|}{2010} & \multicolumn{2}{|c|}{2011} \\
\hline & Valor & $\mathrm{BRL} / \mathrm{TI}$ & Valor & BRL/TI & Valor & BRL/TI & Valor & $\mathrm{BRL} / \mathrm{TI}$ & Valor & $\mathrm{BRL} / \mathrm{TI}$ \\
\hline & USD M & $\%$ & USD M & $\%$ & USD M & $\%$ & USD M & $\%$ & USD M & $\%$ \\
\hline Alemanha & 110 & 1,3 & 170 & 1,4 & 213 & 2,2 & 399 & 3,2 & 684 & 4,5 \\
\hline Estado Unidos & 202 & 1,1 & 214 & 0,8 & 273 & 1,4 & 357 & 1,3 & 536 & 1,6 \\
\hline China & 1 & 0,0 & 5 & 0,0 & 80 & 0,5 & 309 & 1,2 & 467 & 1,4 \\
\hline Brasil * & 0 & 0,1 & 0 & 0,2 & 0 & 0,0 & 588 & 74 & 381 & 51 \\
\hline Suíça & 118 & 5,4 & 136 & 6,1 & 179 & 8,7 & 320 & 11 & 380 & 13 \\
\hline Reino Unido & 1 & 0,1 & 2 & 0,1 & 46 & 1,9 & 145 & 4,6 & 373 & 11 \\
\hline Coreia do Sul & 0 & 0,0 & 100 & 1,8 & 112 & 2,3 & 281 & 3,3 & 343 & 3,4 \\
\hline Suécia & 11 & 0,8 & 15 & 0,9 & 18 & 1,6 & 115 & 6,7 & 129 & 5,9 \\
\hline Japão & 9 & 0,2 & 15 & 0,2 & 51 & 0,9 & 100 & 1,4 & 116 & 1,5 \\
\hline Dinamarca & 18 & 5,0 & 29 & 6,3 & 18 & 5,1 & 39 & 7,2 & 116 & 16 \\
\hline Itália & 9 & 0,3 & 14 & 0,3 & 28 & 0,8 & 121 & 2,5 & 116 & 1,9 \\
\hline Irlanda & 21 & 4,8 & 24 & 4,8 & 55 & 11 & 66 & 12 & 87 & 13 \\
\hline França & 32 & 0,9 & 23 & 0,5 & 43 & 1,2 & 109 & 2,3 & 85 & 1,6 \\
\hline Índia & 1 & 0,0 & 55 & 1,5 & 127 & 5,8 & 23 & 0,5 & 72 & 1,2 \\
\hline Israel & 1 & 0,2 & 2 & 0,1 & 5 & 0,7 & 6 & 0,6 & 68 & 7,5 \\
\hline Malásia & 0 & 0,0 & 6 & 0,4 & 14 & 1,1 & 42 & 2,4 & 63 & 2,8 \\
\hline Porto Rico & - & - & - & - & 17 & 11 & 68 & 32 & 59 & 22 \\
\hline México & 0 & 0,0 & 0 & 0,0 & 8 & 0,3 & 57 & 1,5 & 46 & 0,9 \\
\hline Taiwan & 0 & 0,0 & 2 & 0,0 & 9 & 0,4 & 39 & 1,3 & 41 & 1,2 \\
\hline Tailândia & 0 & 0,0 & 0 & 0,0 & 8 & 0,6 & 22 & 1,2 & 33 & 1,4 \\
\hline Argentina & 2 & 0,0 & 3 & 0,0 & 5 & 0,0 & 23 & 0,2 & 29 & 0,2 \\
\hline Bélgica & 0 & 0,0 & 0 & 0,0 & 6 & 0,5 & 9 & 0,6 & 27 & 1,5 \\
\hline Áustria & 0 & 0,0 & 0 & 0,0 & 3 & 0,3 & 8 & 0,6 & 22 & 1,5 \\
\hline Países Baixos & 0 & 0,0 & 4 & 0,2 & 18 & 1,8 & 19 & 1,1 & 22 & 1,0 \\
\hline Espanha & 0 & 0,0 & 0 & 0,0 & 0 & 0,0 & 6 & 0,2 & 12 & 0,4 \\
\hline Canadá & 11 & 0,7 & 15 & 0,5 & 9 & 0,6 & 4 & 0,2 & 11 & 0,3 \\
\hline Chile & 0 & 0,0 & - & - & - & - & 0 & 0,0 & 11 & 0,2 \\
\hline Uruguai & 5 & 0,7 & 5 & 0,5 & 3 & 0,2 & 1 & 0,1 & 11 & 0,6 \\
\hline
\end{tabular}

Ministério do Desenvolvimento, Indústria e Comércio Exterior - MDIC

Nota: $90 \%$ maiores valores de importações brasileiras faturadas em BRL. Cada ano é dividido em duas colunas: a coluna da esquerda (Valor) é o valor total importado do país em milhões de USD; a coluna da direita (BRL/TI) é a participação do faturamento em BRL nas importações totais, por origem. [*] Vide 2.3.1, para esclarecimento sobre importações originadas do Brasil.

Sinais convencionais utilizados: 0,0 : dado numérico resultante de arredondamento de um dados numérico originalmente positivo, -: dado numérico igual a zero, não resultante de arredondamento.

BRL.

Observamos também que alguns países têm uma elevada proporção de faturamento BRL em relação ao valor total importado no Brasil. A Suíça e o Reino Unido chamam a atenção por terem valores relativamente elevados em termos absolutos das importações faturadas em BRL quando listados por origem como também apresentam valores relativos relativamente altos - mais de um décimo das importações desses países foi faturada em BRL nos últimos anos. A análise dos produtos vendidos em BRL pode contribuir para a compreensão desses valores, então é o que fazemos em seguida.

Após observarmos as origens e destinos, nós focamos agora em entender qual a variedade de produtos que é faturada em BRL. As tabelas $6 a$ e $6 \mathrm{~b}$ nos provêm um panorama de exportações e importações, respectivamente. Ambas as tabelas apresentam, para cada ano, duas informações para cada produto detalhado. A informação à esquerda é o valor total de comércio faturado em BRL em milhões de USD; a informação à direita é a participação do produto no fluxo total faturado em BRL. 
Os principais produtos exportados são energia elétrica, tabaco e açúcar. Eles representam significativa parcela do faturamento das exportações em BRL e serão explorados com mais detalhes na subseções 2.5.2 e 2.5.2. A subseção 2.5.2, que contém a discussão sobre a Argentina, discute a energia elétrica, uma vez que a Argentina foi o único destino deste produto. Uma seção especial (seção 2.5.2) discute o tabaco e o açúcar.

Parte de veículos motores e calçados são então os principais produtos listados nas exportações. Partes de veículos motores são exportados principalmente para a Argentina (95,9\%). O Paraguai tem 3,7\%, a participação remanescente é dividida entre Alemanha $(0,18 \%)$, México (0,04\%), e Índia (0,02\%). Calçados segue um padrão similar, com a Argentina detendo 95,7\% e Paraguai, 3,7\%. Destinos menores incluem a Bolívia (0,34\%), o Uruguai (o,28\%), o Japão (0,01\%), e França (0,003\%). Produtos laminados de ferro fundido, ferro e aço; linha branca; e preparações capilares seguem um padrão similar. Os países do Mercosul são o principal destino para produtos cerâmicos, que são principalmente exportados para o Paraguai (94,4\%).

O padrão em que os parceiros regionais são os destinos primários não se verifica para os demais produtos listados. As bebidas alcoólicas são exportadas em BRL para os Estados Unidos (41,3\%), Paraguai (18,0 \%), Jamaica (14,4 \%), Trinidad e Tobago (13,2 \%), Países Baixos (5,3\%), e outros cinco destinos com menos de $5 \%$ cada. O Reino Unido $(28,8 \%)$, Alemanha (25,1 \%), Estados Unidos (21,5\%), Austrália (9,9\%), Canadá (5,5 $\%$ ), e outros seis (menos de $5 \%$ cada) são destino para a gelatina e derivados.

O principal produto que importadores brasileiros faturam em BRL são produtos farmacêuticos. Eles representavam $60 \%$ das importações totais faturadas em BRL no primeiro ano da série. Apesar de seu crescente montante durante o período observado, sua participação diminuiu, o que é atribuído à diversificação dos produtos na pauta de produtos faturados em BRL.

Alguma atenção é atraída pelo faturamento de produtos farmacêuticos em BRL em razão de serem produzidos por grandes empresas de exportação no mundo inteiro. Seria de se esperar que eles fossem faturados na moeda do exportador, que é a suposição habitual para a escolha moeda de faturamento.

Uma explicação que oferecemos é que estas grandes empresas também têm filiais locais no país de destino. Então farmacêuticos faturar em BRL pode estar relacionado com a logística internacional dentro do mesmo grupo empresarial. Dentro do mesmo grupo empresarial, a escolha da moeda do remetente ou do destinatário pode ser a solução adequada para excluir o risco cambial das contabilidade de uma das filiais. Produtos farmacêuticos são a maior parte das importações faturadas em BRL originadas da Alemanha 
Tabela 6 - Comércio brasileiro faturado em BRL, por produto (2007-11)

(a) Exportações

\begin{tabular}{|c|c|c|c|c|c|c|c|c|c|c|}
\hline \multirow{2}{*}{ Produtos } & \multicolumn{2}{|l|}{2007} & \multicolumn{2}{|l|}{2008} & \multicolumn{2}{|c|}{2009} & \multicolumn{2}{|c|}{2010} & \multicolumn{2}{|c|}{2011} \\
\hline & USD M & $\%$ & USD M & $\%$ & USD M & $\%$ & USD M & $\%$ & USD M & $\%$ \\
\hline Energia elétrica & - & - & - & - & 1066,0 & 64,8 & 343,2 & 21,3 & 274,3 & 8,9 \\
\hline Tabaco & - & - & - & - & - & - & 135,8 & 8,4 & 495,5 & 16,1 \\
\hline Açúcar & 0,2 & 0,1 & 2,7 & 0,9 & 2,5 & 0,2 & 5,8 & 0,4 & 515,5 & 16,8 \\
\hline Partes e acessórios dos veículos automóveis & 3,9 & 2,0 & 7,5 & 2,6 & 18,5 & 1,1 & 128,7 & 8,0 & 291,4 & 9,5 \\
\hline Calçados (produtos acabados) & 4,5 & 2,3 & 4,8 & 1,6 & 71,8 & 4,4 & 142,1 & 8,8 & 158,4 & 5,2 \\
\hline Bebidas alcoólicas & 11,3 & 5,7 & 13,8 & 4,7 & 15,2 & 0,9 & 16,2 & 1,0 & 295,5 & 9,6 \\
\hline Produtos laminados de ferro fundido, ferro e aço & 5,4 & 2,8 & 11,2 & 3,8 & 42,6 & 2,6 & 121,5 & 7,5 & 122,1 & 4,0 \\
\hline Linha branca & 6,0 & 3,1 & 8,0 & 2,7 & 48,6 & 3,0 & 116,0 & 7,2 & 65,9 & 2,1 \\
\hline Gelatina e derivados & 0,0 & 0,0 & 0,0 & 0,0 & 44,3 & 2,7 & 43,0 & 2,7 & 42,5 & 1,4 \\
\hline Xampu e outras preparações capilares & 0,7 & 0,4 & 0,6 & 0,2 & 29,6 & 1,8 & 39,2 & 2,4 & 41,8 & 1,4 \\
\hline Produtos de cerâmica & 13,5 & 6,8 & 21,0 & 7,1 & 17,3 & 1,0 & 26,1 & 1,6 & 30,2 & 1,0 \\
\hline
\end{tabular}

Ministério do Desenvolvimento, Indústria e Comércio Exterior - MDIC

Nota: São detalhados os produtos que representaram mais de $3 \%$ em um ano. A coluna da esquerda contém os valores de produtos faturados em BRL em milhões de USD por ano. A coluna da direita é a participação do produto no total de exportações faturadas em BRL.

Sinais convencionais utilizados: 0,0 : dado numérico resultante de arredondamento de um dados numérico originalmente positivo, -: dado numérico igual a zero, não resultante de arredondamento.

(b) Importações

\begin{tabular}{|c|c|c|c|c|c|c|c|c|c|c|}
\hline \multirow{2}{*}{ Produtos } & \multicolumn{2}{|c|}{2007} & \multicolumn{2}{|c|}{2008} & \multicolumn{2}{|c|}{2009} & \multicolumn{2}{|c|}{2010} & \multicolumn{2}{|c|}{2011} \\
\hline & USD M & $\%$ & USD M & $\%$ & USD M & $\%$ & USD M & $\%$ & USD M & $\%$ \\
\hline Produtos farmacêuticos & 349,3 & 61,4 & 429,0 & 49,8 & 643,6 & 46,6 & 1,306 & 39,3 & 1,601 & 36,3 \\
\hline Máquinas, aparelhos e materiais elétricos & 25,4 & 4,5 & 163,0 & 18,9 & 364,6 & 26,4 & 756,6 & 22,8 & 924,5 & 21,0 \\
\hline Veículos e material para vias férreas ou semelhantes & - & - & - & - & - & - & 570,9 & 17,2 & 369,9 & 8,4 \\
\hline Máquinas, aparelhos & 48,2 & 8,5 & 67,5 & 7,8 & 82,2 & 5,9 & 154,5 & 4,6 & 284,6 & 6,5 \\
\hline Veículos automóveis, tratores e outros veículos terrestres & 0,0 & 0,0 & 0,0 & 0,0 & 0,4 & 0,0 & 0,9 & 0,0 & 221,0 & 5,0 \\
\hline Produtos químicos orgânicos & 8,7 & 1,5 & 3,9 & 0,4 & 11,2 & 0,8 & 28,8 & 0,9 & 209,6 & 4,8 \\
\hline Produtos diversos das indústrias químicas & 51,6 & 9,1 & 81,5 & 9,5 & 76,2 & 5,5 & 91,4 & 2,7 & 177,4 & 4,0 \\
\hline Instrumentos e aparelhos de óptica e de fotografia & 42,3 & 7,4 & 54,2 & 6,3 & 78,4 & 5,7 & 149,5 & 4,5 & 171,6 & 3,9 \\
\hline Bebidas e líquidos alcoólicos & - & - & 0,0 & 0,0 & 31,0 & 2,2 & 55,2 & 1,7 & 128,3 & 2,9 \\
\hline
\end{tabular}

Ministério do Desenvolvimento, Indústria e Comércio Exterior - MDIC

Nota: São detalhados os produtos que representaram mais de $2 \%$ em um ano. A coluna da esquerda contém os valores de produtos faturados em BRL em milhões de USD por ano. A coluna da direita é a participação do produto no total de importações faturadas em BRL.

Sinais convencionais utilizados: 0,0 : dado numérico resultante de arredondamento de um dados numérico originalmente positivo, -: dado numérico igual a zero, não resultante de arredondamento.

(44\%) e dos Estados Unidos $(75 \%)$ e constituem quase a totalidade das importações provenientes da Suíça (90\%). De fato, 28,1\% dos produtos farmacêuticos faturados em BRL vêm dos Estados Unidos, 24,3 \%, da Suíça, e 16,7 \% da Alemanha. Vinte outros países também estão são origem nesta listagem.

Tabela 7 - Participação do faturamento em BRL no total do comércio, por produto e por país $(2007-11)$

\begin{tabular}{lrr|lrr}
\hline \multicolumn{2}{c}{ Exportações faturadas em BRL } & \multicolumn{2}{|c}{ Importações faturadas em BRL } \\
Produto (destino) & USD M & $\%$ & Produto (origem) & USD M & $\%$ \\
\hline Artigos de fibrocimento (Paraguai) & 42.4 & 91 & Produtos químicos: fenóis (Alemanha) & 11.2 & 92 \\
Preparações de tomate (Paraguai) & 28.3 & 90 & Pneus novos (Eslováquia) & 11.8 & 87 \\
Produtos laminados de ferro (Paraguai) & 18.8 & 89 & Antisoro e outras frações de sangue & 916.9 & 85 \\
Energia elétrica (Argentina) & $1,938.5$ & 87 & (Suíça) & 24.6 & 81 \\
Carne de aves (Bolívia) & 13.2 & 83 & Máquinas eletrônicas (Irlanda) & 368.6 & 78 \\
Castanhas (Bolívia) & 17.5 & 77 & Compostos de diagnóstico ou de laboratório & & \\
Óleos de soja (Paraguai) & 27.1 & 77 & reagentes (Alemanha) & & \\
Velas e similares (Paraguai) & 17.4 & 76 & & &
\end{tabular}

Ministério do Desenvolvimento, Indústria e Comércio Exterior - MDIC

Nota: Os produtos listados são aqueles para os quais o fluxo total foi acima de USD 10 milhões e cuja participação seja de $75 \%$ ou superior. Valores refletem o total do fluxo de comércio do Brasil. A participação listada é calculada se dividindo o fluxo em BRL pelo fluxo total. 
Equipamentos elétricos são o próximo item como principal importação faturada em BRL: 30,7\% foram originados a partir de Coreia do Sul, e 29,7\% da China. Índia (10,3\%), Japão (6,7\%), e 50 outros países são os seguinte na lista. China e Coreia do Sul são os destaques em termos de valor total de importações em BRL. Índia, no entanto, é importante quando se considera a participação do faturamento em BRL. Quase a metade dos equipamentos elétricos importados faturados em BRL são originados da Índia em 2009. Para todo o período, 25,3\% destes produtos faturados em BRL foram originados da Índia.

Equipamento para a construção de ferrovias é o produto listado em sequência na tabela 6b, e eles têm o Brasil registrado como sua origem. As operações listadas para estes produtos são aquelas que o produto importado foi fabricado no país de importação. Este tipo de importação parece ter uma característica transitória, focando atender necessidades específicas. Como se concentrar nos últimos anos da série, exige-se observações subsequentes para se confirmar esta hipótese. Os outros produtos listados seguem um padrão em que alguns países são as principais origens do faturamento em BRL e o valor restante é distribuído entre vários pequenos montantes por outros países de origem.

Concluindo nossa descrição do comércio faturado em BRL, vamos nos concentrar sobre os produtos para os quais o BRL foi a principal opção de faturamento. Nós consideramos todo o período e apenas os produtos com um fluxo maior que USD 10 milhões. As participações superiores a 75\% são apresentadas na Tabela 7. Observe que a participação do faturamento em BRL é relevante para os países vizinhos ao Brasil nas exportações, mas o mesmo não ocorre no caso das importações.

\subsubsection{Significante impacto da introdução do sistema de pagamentos}

Diversos países apresentaram um alto crescimento do faturamento em BRL, como observado na tabela 4; os números para 2011 são claramente maiores e mais distribuídos entre os países que aqueles observados nos anos iniciais da série. A Argentina é o destaque, mostrando um padrão distinto. Ela apresentou um crescimento de USD 4,3 milhões para USD 1,3 bilhões em 2011 O faturamento em BRL, que era aproximadamente zero em 2007, foi responsável, em 2010 e 2011, por 6\% do total de exportações para o maior parceiro comercial brasileiro.

Energia elétrica explica muito do crescimento do faturamento em reias nas exportações argentinas. O crescimento começou em 2009 e foi responsável por mais de $75 \%$ do total de exportações em BRL naquele ano. Esta forte participação foi reduzida para $20 \%$ em 2011, sugerindo que o crescimento no faturamento em BRL não foi apenas resultante da adição da energia elétrica na pauta de exportações. 
A influência do governo em grandes contratos de energia sugere a possibilidade de algum viés na escolha moeda de faturamento. Assim, destacamos os valores referentes à energia elétrica dos demais produtos comercializados e os apresentamos na tabela 8, que apresenta os produtos que foram responsáveis por 3\% ou mais das exportações em BRL em pelo menos um dos anos observados. De 2009-10, toda a energia elétrica exportada para Argentina foi faturada em BRL. Este número mudou em 2011, quando apenas um pouco mais da metade foi faturada em BRL. Embora a adição de energia elétrica na pauta de exportações faturadas em BRL tenha adicionado peso ao resultado de crescimento, ele não explica integralmente a mudança total ocorrida no faturamento em BRL. Outros produtos na pauta de exportações também começaram a ser faturados na moeda nacional, contribuindo para a Argentina se tornar líder no uso do BRL no comércio.

Calçados, peças para veículos automóveis e produtos laminados planos de ferro ou aço foram os principais produtos exportados por meio de faturamento em BRL. Em 2011, estes três foram responsáveis por uma exportação total de mais de USD 100 milhões e um crescimento expressivo no início da série, em 2007. Em 2011, mais de $75 \%$ dos calçados foi faturado em BRL. A participação do BRL no faturamento nesse ano para peças para veículos automóveis foi de $13 \%$; para produtos de ferro e aço, que foi de $24 \%$. Por outro lado, placas de madeira, banana, atum e outros produtos principais nos anos anteriores mantiveram o mesmo nível até anos finais da série. A maior diversificação da pauta de exportação faturada em BRL é a explicação para o crescimento global na Argentina e iniciou em 2009.

O argentino-brasileiro Sistema de Pagamentos em Moeda Local (SML) inaugurado no final de 2008 pode explicar tal mudança notável no comportamento do faturamento de exportações para a Argentina. O SML é operado pelo banco central dos dois países e suas ordens de pagamento proveem uma operação de câmbio agregada entre o BRL e o ARS. A conveniência de o banco central prover uma transação de câmbio no âmbito do sistema internacional de transferência de pagamentos é um apelo para os comerciantes. Os comerciantes que utilizam o sistema de pagamento são obrigados a faturar as exportações em moeda nacional, por regulamentação.

Grosso modo 51\% do valor faturado em BRL foi pago por meio de ordens de pagamento SML desde seu lançamento até 2011. A comparação da base de dados do MDIC diretamente à base de dados do SML pode ser enganosa, no entanto. Temos de estar conscientes das incompatibilidades de metodologia quando tal comparação é feita. Os dados do MDIC consistem em mercadorias embarcadas, e seu preço registado é o preço FOB convertido do valor original em BRL para USD pela taxa de câmbio da data da declaração de exportação. Os dados do SML consistem em pagamentos financeiros registados em BRL e consolidados mensalmente. Para a comparação de magnitude que 
Tabela 8 - Exportações faturadas em BRL para a Argentina, por produto (2007-11)

\begin{tabular}{|c|c|c|c|c|c|}
\hline & 2007 & 2008 & 2009 & 2010 & 2011 \\
\hline Total de exportações faturadas em BRL (USD M) & 4,3 & 12,4 & 1361,2 & 1106,0 & 1327,3 \\
\hline Exportações de energia elétrica faturadas em BRL (USD M) & - & - & 1066,0 & 343,2 & 274,3 \\
\hline ... participação nas exportações em BRL para a Argentina (\%) & 0 & 0 & 78 & 31 & 21 \\
\hline ... participação no total de energia elétrica exportada(\%) & 0 & 0 & 100 & 100 & 52 \\
\hline Exportações, excl. energia elétrica (USD M) & 4,3 & 12,4 & 295,2 & 762,8 & 1053,1 \\
\hline \multicolumn{6}{|l|}{ Produtos (USD M) } \\
\hline Calçados & - & - & 79,7 & 152,6 & 191,7 \\
\hline ... Produtos acabados & - & - & 69,5 & 135,4 & 150,0 \\
\hline ... Partes de calçados & - & - & 10,2 & 17,2 & 41,6 \\
\hline Partes de veículos automóveis & - & 0,3 & 13,5 & 121,2 & 283,9 \\
\hline Produtos laminados de ferro fundido, ferro e aço & - & 1,9 & 32,6 & 108,2 & 108,1 \\
\hline Linha branca & - & - & 43,6 & 111,3 & 60,0 \\
\hline Xampús e outros preparos capilares & - & - & 29,1 & 38,3 & 40,7 \\
\hline Pneus de borracha novos & - & - & - & 12,2 & 58,5 \\
\hline Receptores de televisão & - & - & 3,0 & 39,8 & 19,9 \\
\hline Mobília & - & 0,1 & 9,6 & 18,0 & 19,3 \\
\hline Placas de madeira & 2,7 & 2,0 & 1,5 & 1,9 & 1,7 \\
\hline Bananas & 1,0 & 1,3 & 2,3 & 2,2 & 1,8 \\
\hline Atum & - & 0,5 & 3,5 & 3,8 & 5,0 \\
\hline Placas ou folhas de poliuretano celular & - & 0,6 & 4,1 & 2,0 & 3,1 \\
\hline Placas e painéis elétricos & - & 0,5 & 0,0 & - & 0,3 \\
\hline Cebolas e chalotas & 0,6 & 0,1 & 0,0 & 0,0 & 0,2 \\
\hline Reservatórios ou tanques de ferro & - & 0,4 & 0,3 & 0,0 & \\
\hline Partes de aquecedores & - & 0,7 & 3,2 & 0,0 & - \\
\hline Transformadores e indutores elétricos & - & 1,4 & 0,2 & 0,0 & 0,0 \\
\hline Outros bens & 0,2 & 2,5 & 68,9 & 151,3 & 259,0 \\
\hline
\end{tabular}

Source: Ministry of Development, Industry and Foreign Trade

Note: Products accounting for over $3 \%$ a year are detailed.

Conventions used: 0.0: numerical data resulting from rounding an originally positive numeric data, -: numeric data equals zero, not due to rounding.

apresentamos, nós convertemos os dados mensais do SML para USD usando a taxa de câmbio média do mês. Na subseção 2.5.3, nós vamos aprofundar a comparação entre essas duas bases de dados.

O lançamento do SML se sobrepõe ao agravamento da crise financeira internacional de 2007-8, a qual poderia ser uma explicação alternativa para dois grandes parceiros comerciais confiarem em suas moedas nacionais como uma referência de faturamento. A crise financeira afetou as relações do Brasil com os países, criando uma possível explicação para o efeito global faturamento em BRL. Avaliar precisamente este efeito e avaliar se o crescimento do faturamento em BRL é uma tendência a ser mantida exigiria uma série de tempo mais longa. No entanto, é certo que a política que estabeleceu o SML conferiu a comerciantes uma maneira conveniente de usar a moeda nacional, influenciando consequentemente na sua decisão sobre a escolha de moeda. 
Nós então usamos os dados disponíveis para avaliar se a introdução das ordens de pagamento do SML apresentou uma correlação significativa com o uso do BRL no faturamento de exportações. Devido ao grande conjunto de soluções de canto, aplicamos o modelo tobit nos dados em painel e regredimos a participação do faturamento em BRL na disponibilidade do SML, controlando para os efeitos posteriores à crise financeira internacional, para a relevância do comércio entre o Brasil e a contraparte, para o volume de comércio e para a volatilidade cambial. Nós fazemos seis regressões considerando efeitos específicos para a combinação entre país e produto (ao nível de 2 dígitos da NCM), segundo a equação geral da descrita por:

$$
\begin{gathered}
\operatorname{SHARE}_{c, p, t}=\max \left\{\beta \cdot \mathrm{SML}_{c, t}+\alpha \cdot \text { crisis }_{t}+r e l_{c, p, t} \delta_{1}+t v_{c, p, t} \delta_{2}+\right. \\
\left.+\operatorname{xrt}_{c, t} \delta_{3}+h s_{p} \gamma_{1}+c n t_{c} \gamma_{2}+u_{c, p, t}, 0\right\}
\end{gathered}
$$

em que $\mathrm{SHARE}_{c, p, t}$ é a participação do BRL nas exportações e as variáveis explicativas são:

- $\mathrm{SML}_{c, t}$ é específico por país e por tempo e indica a disponibilidade do SML. A variável é construída pela interação entre a indicação dummy se o SML esteve disponível durante o ano e a proporção de meses em que ele esteve disponível no dado ano;

- crisis $_{t}$ é específico por país e indica os efeitos sobre o faturamento em BRL ocorridos em todos os países após a quebra do Lehman Brothers e a piora da crise financeira internacional de 2008;

- $r e l_{c, p, t}$ é o vetor específico por produto (NCM, 2 dígitos), país e tempo que contém a relevância do Brasil no comércio com o país de destino. O Brasil é avaliado como fornecedor, destino e parceiro comercial e as variáveis são construídas a partir da base de dados UN Comtrade, segundo os dados reportados por cada país contra-parte. A relevância como fornecedor $\left(\right.$ rel $\left._{s_{c, p}}\right)$ é a divisão entre as importações originadas no Brasil e as importações totais do país. A relevância como destino $\left(r e l_{d_{c, p}}\right)$ é a divisão entre as exportações destinadas ao Brasil e o total de exportações do país. A relevância como parceiro comercial $\left(r e l_{t p_{c, p}}\right)$ é calculada a partir dos dados das correntes de comércio;

- $t v_{c, p, t}$ é o vetor específico por produto (NCM, 2 dígitos), país e tempo que contém o logaritmo dos dados de exportação $\left(t v_{x}\right)$ e importação $\left(t v_{m}\right)$ do MDIC para o país contraparte a preços correntes. Observados os comentários constantes da subseção 2.3.1, os resultados da regressão não mostraram diferença significativa entre os dados a preços corrente e a preços deflacionados; 
- $x r t_{c, t}$ é específico por país e tempo e indica a volatilidade da taxa de câmbio da moeda no país de destino. A volatilidade da taxa de câmbio ;e o coeficiente de variação da moeda durante o dado ano;

- $h s_{p}$ e $c n t_{c}$ são os vetores que contém as variáveis dummy que agregam respectivamente os efeitos específicos por produto e por país.

Os resultados são apresentados na tabela 9 e as seis regressões descritas nas colunas de (1) a (6). Nós empregamos diferentes configurações para entender como a escolha de diferentes modelos afeta a conclusão sobre o efeito SML. Em (1)-(3), para além dos efeitos de conjuntos de produto e país, nós consideramos efeitos específicos para cada tipo de produto e para cada país. Diferentes modelagens destes efeitos são usadas em (4)-(6). A relevância é significativa conjuntamente em (1) e em (2). Não importa qual seja o modelo escolhido, nós encontramos que o SML é significativo ao nível de 0,1\%. Este resultado confirma o vínculo entre a política do governo brasileiro de introduzir as ordens de pagamento do SML e da maior ocorrência de faturamento em BRL. Neste sentido, a relação entre a disponibilidade de instrumentos financeiros e a escolha da moeda de faturamento surge.

Tabela 9 - SML e participação do faturamento em BRL nas exportações

\begin{tabular}{|c|c|c|c|c|c|c|}
\hline \multicolumn{7}{|c|}{ Variável dependente: participação de exportações faturadas em BRL, por país } \\
\hline & $(1)$ & $(2)$ & $(3)$ & $(4)$ & $(5)$ & $(6)$ \\
\hline SML & $0,208^{* * *}$ & $0,209 * * *$ & $0,206 * * *$ & $0,204^{* * *}$ & $0,250 * * *$ & $0,282^{* * *}$ \\
\hline Crise & $0,0809 * * *$ & $0,0801 * * *$ & $0,0944^{* * *}$ & $0,0929^{* * *}$ & $0,0924^{* * *}$ & $0,0866 * * *$ \\
\hline \multicolumn{7}{|l|}{ Relevância como... } \\
\hline ..fornecedor & $-0,0102$ & 0,0157 & & & & \\
\hline ..destino & $-0,0116$ & 0,0390 & 0,0302 & $-0,0304$ & $0,582^{* * *}$ & $0,434^{* * *}$ \\
\hline ..parceiro comercial & 0,0924 & & & & & \\
\hline \multicolumn{7}{|l|}{ Volume de comércio $(\log ) \ldots$} \\
\hline ..total exportado & $0,0171^{* * *}$ & $0,0170^{* * *}$ & $0,0182^{* * *}$ & $0,0228 * * *$ & $0,0416^{* * *}$ & $0,0291^{* * *}$ \\
\hline ..total importado & $0,000811^{*}$ & & & & & \\
\hline Volatilidade cambial & $0,000772^{*}$ & $0,000798^{*}$ & $0,00105^{* *}$ & $0,00102^{* *}$ & 0,0000603 & 0,000153 \\
\hline Controle para produtos & $\operatorname{sim}$ & $\operatorname{sim}$ & $\operatorname{sim}$ & & $\operatorname{sim}$ & \\
\hline Controle para países & $\operatorname{sim}$ & $\operatorname{sim}$ & $\operatorname{sim}$ & $\operatorname{sim}$ & & \\
\hline Constante & $-1,520$ & $-1,539$ & $-1,901$ & $-1,837$ & $-1,340^{* * *}$ & $-1,054^{* * *}$ \\
\hline$\sigma_{u}$ & $0,141^{* * *}$ & $0,141^{* * *}$ & $0,151^{* * *}$ & $0,184^{* * *}$ & $0,248^{* * *}$ & $0,276^{* * *}$ \\
\hline$\sigma_{e}$ & $0,149^{* * *}$ & $0,149^{* * *}$ & $0,165^{* * *}$ & $0,164^{* * *}$ & $0,163^{* * *}$ & $0,161^{* * *}$ \\
\hline Log verossimilhança & $-615,77$ & $-619,45$ & $-892,48$ & $-1146,2$ & $-1561,6$ & $-1773,7$ \\
\hline $\mathrm{N}$ & 14487 & 14487 & 24556 & 24556 & 24556 & 24556 \\
\hline N (não censurado) & 1102 & 1102 & 1453 & 1453 & 1453 & 1453 \\
\hline
\end{tabular}

Nota: Relevância como fornecedor é o total de importações do Brasil divido pelo total de importações do país. Relevância como destino é o total de exportações para o Brasil dividido pelo total de exportações do país. A relevância como parceiro comercial é calculada a partir das participações na corrente de comércio.

Sinais convencionais utilizados: Coeficientes beta: ${ }^{*} \mathrm{p}<0.05,{ }^{* *} \mathrm{p}<0.01,{ }^{* * *} \mathrm{p}<0.001$.

Como discutiremos na subseção 2.5.3, o SML foi responsável por quase $80 \%$ dos números argentinos dos anos de 2010 e 2011. Os 20\% restantes - mesmo excluindo os 
valores relativos à energia elétrica - representam um montante superior ao valor observado antes da disponibilidade do SML. As ordens de pagamento em moeda local podem não só ter impactado a escolha da moeda de faturamento pela disponibilidade do instrumento financeiro diretamente, como também por um efeito de coalescência - o que deixamos para avaliações futuras com um série mais longa.

Ao contrário das exportações, nenhuma intervenção governamental pode ser creditada ao crescimento do uso do BRL nas importações, pelo menos de forma direta. Nós sugerimos que o Sistema de Pagamentos em Moeda Local (SML) foi uma razão parcial para o crescimento das exportações faturadas em BRL. No caso de pagamentos relativos a importações brasileiras, o sistema de pagamentos bilateral requer que as operações sejam faturadas em ARS. Assim, não há nenhum impacto direto na utilização do BRL. Na subseção 2.5.3 vamos analisar os dados financeiros relativos ao comércio.

Como observado na subseção 2.5.1, Argentina não é uma origem relevante de produtos faturados em BRL tal qual o é relevante como destino de exportações faturadas em BRL. Com efeito, o faturamento na moeda brasileira é de apenas $0,2 \%$ do total das importações. Apenas 30 produtos usaram o BRL como moeda de faturamento durante o período observado. Produtos farmacêuticos foram responsáveis por quase $70 \%$ das importações totais em BRL ao longo do período, com vacinas veterinárias tendo uma participação de 44\%. Elas são quase completamente faturadas em BRL. Os medicamentos foram responsáveis por outros $25 \%$, e outros produtos farmacêuticos e alguns produtos de plástico só foram faturados em BRL em 2007 e 2008. Nos últimos anos da série, o número de diferentes produtos aumentou para cerca de 20, confirmando uma maior diversificação da cesta, da mesma forma que foi relatado para as exportações.

Açúcar e tabaco ${ }^{10}$ são os dois principais produtos exportados em BRL (tabela 6a). A liderança desses produtos na lista levanta uma questão intrigante. Como eles são produtos homogêneos no mercado internacional e são negociados em bolsas de mercadorias, esperaríamos que os comerciantes recorressem a uma moeda internacional para os faturar (MCKINNON, 1979; KRUGMAN, 1980b). Evidências neste sentido foram registradas por Goldberg e Tille (2008) e Devereux, Shi e Xu (2010). O que encontramos nos dados do comércio brasileiro é o oposto no entanto. A moeda local não-internacional do exportador, o BRL, foi utilizada para realizar o faturamento.

Uma possível explicação é considerar a existência de algum poder de barganha impactando a escolha moeda de faturamento (GOLDBERG; TILLE, 2013). O Brasil responde por mais de $40 \%$ das exportações mundiais de açúcar e mais de $12 \%$ as exportações

10 Ao longo deste trabalho, queremos dizer com açúcar o HS 1701-açúcar de cana ou de beterraba e sacarose pura química, forma sólida; e pelo tabaco o HS 2401 — tabaco não manufaturado]]; salvo indicação contrária. 
de tabaco do mundo. Assim, esta grande relevância nas exportações mundiais sugere que possa haver algum poder de barganha, em adição à esperada preferência pelo uso de moedas internacionais nos mercados internacionais.

Tabela 10 - Exportações brasileiras de açúcar faturadas em BRL, por país (2007-11)

\begin{tabular}{lrrrrr}
\hline Destino das exportações de açúcares (USD M) & 2007 & 2008 & 2009 & 2010 & 2011 \\
\hline Emirados Árabes Unidos & - & - & - & - & 126,8 \\
Canadá & - & - & - & - & 65,9 \\
Nigeria & - & - & - & - & 48,9 \\
Gana & - & - & - & - & 28,0 \\
Colômbia & - & - & - & - & 24,5 \\
Yemen & - & - & - & - & 22,1 \\
Venezuela & - & - & - & - & 21,7 \\
África do Sul & - & - & - & - & 20,7 \\
Angola & - & - & - & - & 15,8 \\
Paraguai & 0,1 & 1,7 & 2,3 & 5,3 & 4,4 \\
Estados Unidos & - & - & - & - & 12,5 \\
China & - & - & - & - & 12,4 \\
Algéria & - & - & - & - & 11,6 \\
Bolívia & 0,1 & 0,9 & 0,2 & 0,5 & 8,6 \\
México & - & - & - & - & 10,1 \\
& & & & & \\
Total de países (qtd) & 2 & 3 & 3 & 3 & 40 \\
\hline
\end{tabular}

Ministério do Desenvolvimento, Indústria e Comércio Exterior - MDIC

Nota: País que representam mais de 1,5\% das exportações faturadas em BRL durante 2007-11 estão listados.

Sinais convencionais utilizados: 0,0 : dado numérico resultante de arredondamento de um dados numérico originalmente positivo, -: dado numérico igual a zero, não resultante de arredondamento.

Em 2011, o açúcar foi o produto líder na lista de produtos faturados em BRL. Naquele ano, 3,5\% de todo o açúcar exportado foi faturado em BRL, que é uma participação substancialmente maior que o 1,3\% observados quanto às exportações totais. A tabela 10 relaciona as exportações de açúcar faturadas em BRL descritas por país. Os Emirados Árabes Unidos foram o destino de cerca de um quarto do total naquele ano, o único ano em que houve exportações faturadas na moeda a este país durante a série. O açúcar também foi um produto relevante nas exportações faturadas em BRL para os Estados Unidos; foi a segunda maior receita faturada em BRL para este destino. Dois outros destinos que também foram destaque nas exportações de açúcar são: o Canada (USD 66 milhões) e a Nigéria (USD 44 milhões). Gana, Colômbia, Venezuela, Iêmen, e África do Sul são os destinos que importaram açúcar faturado em BRL na ordem de USD 20-30 milhões cada. Pode-se depreender dos dados que houve, ao menos, um ensaio de se faturar um produto homogêneo na moeda do exportador no último ano da série. 
Assim como o açúcar, o tabaco se destacou no faturamento em BRL. O tabaco não manufaturado, que representa quase a totalidade das exportações de tabaco do Brasil, foi a forma de apresentou com o maior faturamento na moeda local. Em 2011 (tabela 11), 17\% das exportações de tabaco foram faturadas em BRL; esta participação foi de $5 \%$ no ano anterior e não ocorreu antes disso. Na forma manufaturada, apenas $1 \%$ foi faturado em BRL em 2011. Os principais destinos foram a Bélgica, Rússia, Alemanha, Países Baixos, Polônia, Turquia e China.

Tabela 11 - Exportações brasileiras de tabaco faturadas em BRL, por país (2007-11)

\begin{tabular}{lrrrrr}
\hline Destino das exportações de tabaco (USD M) & 2007 & 2008 & 2009 & 2010 & 2011 \\
\hline Bélgica & - & - & - & 124,42 & 167,12 \\
Russia & - & - & - & - & 69,25 \\
Alemanha & - & - & - & - & 52,03 \\
Países Baixos & - & - & - & - & 44,29 \\
Polônia & - & - & - & - & 24,69 \\
Turquia & - & - & - & - & 20,35 \\
China & - & - & - & - & 15,37 \\
Portugal & - & - & - & - & 13,91 \\
Irlanda & - & - & - & - & 11,83 \\
Reino Unido & - & - & - & 9,17 & 0,47 \\
& - & & & & \\
Total de países (qtd) & - & - & - & 6 & 31 \\
\hline
\end{tabular}

Ministério do Desenvolvimento, Indústria e Comércio Exterior - MDIC

Nota: País que exportaram pelo menos USD 10 milhões de tabaco não manufaturado (NCM 2401) no período 2007-11 estão relacionados.

Sinais convencionais utilizados: 0,0 : dado numérico resultante de arredondamento de um dados numérico originalmente positivo, -: dado numérico igual a zero, não resultante de arredondamento.

Como os dados globais, as exportações de tabaco em BRL foram distribuídas entre vários destinos. Não houve eventos até 2009, mas o número de países de destino aumentou acentuadamente para $31 \mathrm{em} \mathrm{2011.} \mathrm{Mesmo} \mathrm{que} \mathrm{as} \mathrm{mesmas} \mathrm{empresas} \mathrm{tenham} \mathrm{exportado}$ tabaco denominado em reais, conclui-se que um maior número de importadores passou a aceitar essa denominação.

O tabaco foi o principal produto exportado para a Bélgica, que apresentou apenas alguns outros itens faturados em BRL. Para esse destino, partes de máquinas também foram denominados em BRL em um nível comparável ao que foi exportado para países vizinhos do Brasil. Os principais destinos das exportações faturadas em BRL foram a Alemanha e os Países Baixos em relação ao tabaco, considerando o maior volume exportado durante todo o período da série avaliada. A Rússia não está incluída nesta lista porque as exportações para lá em BRL só começaram em 2011. 


\subsubsection{Há coincidência das moedas de faturamento e de pagamento?}

Depois de analisarmos o faturamento em BRL, a pergunta imediata é como estas operações comerciais são pagas. O faturamento em uma moeda específica pode significar a distribuição de risco cambial entre o exportador e o importador. O pagamento em uma determinada moeda sinaliza a dependência da disponibilidade das moedas como meio de troca entre as partes. As operações de comércio faturadas em BRL são também pagas na moeda brasileira? Será que as moedas de faturamento e de pagamento coincidem no comércio brasileiro? Como a escolha da moeda de pagamento funciona para uma moeda que não é amplamente disponível no mercado internacional?

Alguns pesquisadores estão igualmente interessados nestas discussões para outros países e moedas. Friberg e Wilander (2008) relataram a partir de uma pesquisa com exportadores suecos que as moedas usadas para o faturamento e o pagamento das operações comerciais são usualmente coincidentes, enquanto estudando o caso da coroa sueca. Analogamente, Ito et al. (2013) promoveram um amplo estudo questionando todas as empresas manufatureiras japonesas relacionadas na Bolsa de Tóquio sobre a moeda usada para o faturamento. Eles também acharam que a moeda usada no faturamento coincide com aquela usada para o pagamento. O modelo teórico de moedas internacionais desenvolvido por Zhang (2014) concluiu por resultados compatíveis a estes resultados empíricos.

Aqui, nós não utilizamos pesquisas com as firmas para tratar desta questão. Em seu lugar, nós nos beneficiamos do grande nível da supervisão brasileira sobre as transações com o exterior. Embora, em consonância com as regras relacionadas ao sigilo bancário, não haja dados a nível de empresa que possam ser utilizados, a ampla cobertura de registro de operação pode nos ajudar a identificar se a hipótese de a coincidência das moedas de faturamento e de pagamento ser válida para o comércio brasileiro.

A liquidação financeira (pagamento) e a liquidação comercial (embarque de produtos) geralmente não ocorrem na mesma data. A data do embarque pode também não coincidir com a data de registro da operação comercial. Assim, comparar os dados do comércio com os dados financeiros pode ser complicado. Adicionalmente, os dados de comércio registrados são geralmente valores FOB ${ }^{11}$ enquanto a operação financeira incluiria os frete e seguro quando possível. Tendo estas questões em mente, nós relacionamos ambas as bases de dados de forma a verificar se as moedas usadas no faturamento e no pagamento coincidem.

De 2007 até 2011, apenas 0,03\% do total de transferências internacionais de reais

11 De acordo com o INCOTERMS 2010, valores FOB são aqueles que consideram o valor do bem sem a adição dos valores relativos a frete e seguro. 
Tabela 12 - Relação entre operações financeiras relacionadas ao comércio denominadas em BRL e o comércio faturado em BRL, 2007-11

\begin{tabular}{|c|c|c|c|}
\hline \multirow{2}{*}{ País } & \multicolumn{2}{|c|}{ Participação de pagamentos no comércio (\\
%) } & \multirow{2}{*}{$\begin{array}{r}\text { Corrente financeira relacionada ao comércio } \\
\text { (USD milhões) }\end{array}$} \\
\hline & Remessas do exterior / Exportações & Remessas ao exterior / Importações & \\
\hline Mundo & 28,6 & 0,1 & $1.967,0$ \\
\hline$\ldots T I R$ & 0,2 & 0,1 & 17,6 \\
\hline Argentina & 51,3 & - & $1.949,8$ \\
\hline$\ldots T I R$ & 0,0 & - & 0,3 \\
\hline$\ldots S M L$ & 51,4 & $n / a$ & $1.949,4$ \\
\hline Itália & 11,6 & - & 0,4 \\
\hline Japão & 3,3 & - & 0,4 \\
\hline Paraguai & 0,8 & - & 8,3 \\
\hline Estados Unidos & 0,5 & - & 1,0 \\
\hline Angola & - & 863,0 & 0,2 \\
\hline Alemanha & - & 0,4 & 6,8 \\
\hline China & - & 0,0 & 0,0 \\
\hline
\end{tabular}

Fonte: Ministério do Desenvolvimento, Indústria e Comércio Exterior - MDIC; Banco Central do Brasil - BCB

Nota: TIR e SML se referem,respectivamente, a ordens de pagamento TIR e ordens de pagamento SML. Comércio se refere aos dados do MDIC. Como as ordens de pagamento são emitidas na moeda do remetente, as transferências ao exterior no SML são exclusivamente denominadas em ARS; não em BRL. * Calculado para o período entre outubro de 2008 e dezembro de 2011, quando o SML estava operacional. Os dados foram convertidos de BRL para USD pela média mensal da média diária das taxas de câmbio (PTAX).

Sinais convencionais utilizados: $0,0:$ dado numérico resultante de arredondamento de um dados numérico originalmente positivo, -: dado numérico igual a zero, não resultante de arredondamento, n/a: não aplicável.

(TIR) foi relacionado ao comércio. Durante todo o período, o volume de pagamentos denominado em BRL foi um pouco superior a $11 \%$ do valor de comércio faturado em BRL. O SML foi responsável por USD 1,96 milhões e as TIR relacionadas ao comércio por apenas USD 18 milhões para um total de USD 17,40 bilhões de comércio faturado em BRL.

Este encaixe de $11 \%$ nas operações relacionadas ao comércio em BRL são um significativo contraste ao encaixe de $98 \%$ que é observado no valor total das transações, quando desconsiderada a moeda de denominação. Este achado poderia desafiar nossa hipótese inicial que todas as transações estariam sob regulamentação brasileira ${ }^{12}$ e então, em adição às considerações anteriormente feitas, nós poderíamos esperar um viés para baixo quando comparado ao total dos registros financeiros relacionados ao comércio. Entretanto, os valores de registros financeiros relacionados ao comércio são praticamente os mesmos que os de comércio no período de 2007 a 2011 no Brasil e não há nenhuma evidência que aponte no sentido da provisão de serviços financeiros em BRL no exterior, o que reforça nosso achado de descasamento entre a moeda de faturamento e a moeda de pagamento.

Descasamento similar também foi relatado por Bo (2013) para os dados chineses, mas em um sentido oposto. Para a China, o valor faturado em renminbi (CNY) é menor que o valor de pagamentos em $56 \%$.

A tabela 12 mostra a percentagem de pagamentos financeiros denominados em BRL sobre o comércio bilateral faturado nesta moeda. Todos os países contraparte para

12 Até agosto de 2006, os exportadores brasileiros eram obrigados a repatriar todos os pagamentos recebidos do comércio. Desde então, manter no exterior parte de suas receitas foi permitido. Desde março de 2008, a repatriação de receitas não é mais necessária. 
as ordens de pagamento TIR durante o período 2007-2011 são apresentados. Para a Argentina, nós incluímos, de forma destacada, os pagamentos SML no cálculo. Neste caso, o período considerado começa em outubro de 2008, quando o serviço de pagamento foi lançado.

A partir da tabela, podemos ver que Angola é o único país em que os pagamentos em BRL superam o faturamento na moeda. Pagamentos originados de Angola só ocorreram no final de 2008. Portanto, é razoável assumir que o embarque da mercadoria relacionada ocorreu durante o período de observação de nossa série, o que sugere que a moeda de faturamento não foi o BRL.

Todos os países apresentam pagamentos denominados em BRL em um ano e nenhum pagamento no ano anterior ou nos anos seguintes. Denominar pagamentos na moeda brasileira parece ser substancialmente incomum. Os Estados Unidos e Alemanha são exceções. Respectivamente, oitenta e quatro e sessenta e sete pagamentos foram feitos a partir de ou para estes países distribuídos ao longo de vários anos, sugerindo um uso mais comum para alguns agentes, ainda que permaneçam como uma pequena parte do comércio total.

Uma questão interessante surgem dos valores da Argentina. Pagamentos em reais não ocorreram a partir de ou para este país antes do lançamento SML. Após o provimento deste serviço pelos bancos centrais, observam-se alguns poucos pagamentos por meio de TIR. No entanto, os pagamentos SML representam mais da metade do total dos pagamentos argentinos faturados em BRL durante seu período operacional. Se analisarmos os dados relativos aos últimos dois anos da série, o montante dos pagamentos SML equivale a mais de $80 \%$ do valor exportado.

Olhando em grandes números, vemos que a moeda usada para o faturamento e para o pagamento não coincidem nos dados do comércio brasileiro faturado em BRL. Assim, o crescimento relatado no comércio faturado em BRL não indica um crescimento da utilização de BRL como um meio de pagamento. O crescimento no faturamento parece ter sido ocasionado por causas diferentes de avanços na liquidez para esta moeda.

\subsection{Comentários finais}

Nós relatamos que o BRL é utilizado como moeda de faturamento no comércio exterior brasileiro. Pela primeira vez, ao nosso conhecimento, um banco de dados de comércio exterior brasileiro foi utilizado para avaliar a escolha da moeda de faturamento. Como resultado, um número de questões intrigantes foram levantados. É, para nós, claro que futuras extensões da presente pesquisa podem prover inúmeros resultados interessantes 
adicionais sobre a moeda brasileira e seu uso no cenário internacional.

A compreensão de moedas locais - a maioria das quais apresentam consideráveis restrições no uso internacional - em um ambiente em que uma moeda global prevalece largamente permite destacar particularidades de economias regionais. Seu estudo requer a máxima atenção aos efeitos secundários causados sobre os agentes e os efeitos por eles causados. Reforça-se assim a sensibilidade destas questões em análise.

Nós mostramos como o BRL é usado para faturar o comércio exterior brasileiro. Do ponto de vista do comércio, nós também apontamos uma variedade de questões relacionadas ao status no BRL no cenário internacional - estas questões permitem e demandam futuras análises específicas. Sobretudo, no presente artigo, nós afastamos a noção de que a moeda brasileira não consegue sobreviver quando contrastada com outras moedas de reconhecido caráter internacional. No comércio Brasil - Estados Unidos, quando contrastado com a moeda mais proeminente internacionalmente na atualidade, nós observamos que os agentes econômicos decidem faturar em BRL em alguns casos. As condições para esta ocorrência permanecem em aberto, sugerindo aprofundamentos futuros.

Questões intrigantes no faturamento internacional surgiram das evidências brasileiras. Nós encontramos que os produtos faturados em BRL que resultam em um maior volume exportado não são aqueles que esperaríamos de acordo com a teoria. O tabaco e o açúcar, ambos produtos homogêneos e comercializados em mercados globais, lideram a pauta de produtos exportados em BRL.

Nós também encontramos que as exportações para a Argentina faturadas em BRL apresentaram um excepcional crescimento no uso do BRL. Destacamos então o estímulo governamental em prover ordens de pagamento bilaterais associadas a operações de câmbio como sua causa. A ausência de liquidez de câmbio e de instrumentos financeiros pode ser custosa para os comerciantes; lidar com estas restrições influencia a escolha da moeda de faturamento pelo agentes.

Adicionalmente, encontramos que o uso do BRL como moeda de faturamento não coincide com o seu uso como moeda de pagamento. Este resultado em termos do comércio exterior brasileiro em BRL não corresponde aos resultados obtidos anteriormente a partir da observação de firmas suecas e japonesas, em que a mesma moeda realiza os dois papéis nas operações comerciais. No Brasil, entretanto, encontramos que o uso da moeda diverge. Condições que fazem com que os agentes escolham faturar em BRL subsistem mesmo se o uso do BRL como moeda de pagamento é altamente restrito. Este é um resultado similar ao ocorrido na China, mas na direção oposta - lá, os pagamentos na moeda local ocorrem mesmo quando o faturamento é incipiente. 
Em última análise, no trabalho aqui relatado, nós mostramos que o BRL é livremente utilizado para faturar comércio exterior brasileiro. Se o USD prevalece no comércio brasileiro, a presença do BRL na parte restante tem crescido em relação a outras moedas internacionais. Assim, a discussão sobre se há algum papel no comércio exterior deve se transformar para as causas do faturamento em BRL e para o nível da sua utilização. Estas perguntas contribuem para a compreensão da utilização internacional do BRL.

Quando o comerciante internacional prefere o real? Quais as condicionantes para o faturamento em reais? Em que grau a escolha de se ter uma moeda nacional brasileira impacta na produção dos agentes nacionais por esta moeda não ser internacional? Na ausência de restrições existentes em decorrência da não-internacionalidade do real, qual seria o percentual esperado de comércio em moeda nacional? Se agora estas questões sobre o BRL parecem atrativas e demandam respostas, este artigo bem cumpriu sua missão - novas perguntas estão colocadas para discussão. 
Parte III

Ensaio 3 


\section{Moedas internacionais, políticas sobre a moeda e distribuição de renda}

\subsection{Introdução}

Existem dois tipos de moedas - moedas globais e moedas locais. A diferença entre elas é o alcance das interações econômicas sobre as quais elas podem desempenhar as funções de uma moeda. Moedas locais são apenas aceitas nas interações econômicas entre os agentes residindo na mesma economia, enquanto moedas globais são aceitas em interações econômicas entre agentes residentes em economias distintas. Políticas de internacionalização da moeda são políticas governamentais que buscam transformar uma moeda local em uma moeda global.

Adicionalmente, os governos podem adotar diferentes posturas em relação às moedas que emitem: desde promover ligeiramente seu uso na economia, recolhendo tributos locais exclusivamente denominados na moeda sua de emissão, até obrigar que ela seja utilizada, banindo o uso de qualquer outra moeda na economia local. Os motivos para a adoção destas posturas variam e não os discutiremos aqui. Vamos nos concentrar nos impactos da escolha destas políticas sobre os agentes residentes no país emissor da moeda e em suas interações com o mundo. Assim, associaremos estas políticas locais sobre o uso da moeda por agentes residentes com as implicações de se ter uma moeda com potencial de uso por agentes não-residentes.

A internacionalização de uma moeda - asssim como as políticas correspondentes-já foram matéria de atenção na literatura. Os principais argumentos para a adoção deste tipo de medida são: (i) os ganhos de senhoriagem dos agentes (COHEN, 1971); (ii) os impactos sobre as políticas macroeconômicas da economia emissora ${ }^{1}$; (iii) os impactos nos custos de transação dos agentes (SWOBODA, 1968); (iv) a mitigação de risco de câmbio dos agentes; (iv) reputação, influência política e poder monetário (KIRSHNER, 1995); e (v) conveniência para os agentes (FRANKEL, 2012).

Um fato que tem sido negligenciado é o impacto redistributivo dessas políticas de internacionalização. Esta desatenção é consequente das questões que já atraíram os pesquisadores para este tema. Alguns exemplos destas questões que atraíram a atenção

1 As consequências da internacionalização da moeda não são claras. Papaioannou e Portes (2008) afirmam que não há evidências que sustentem a existência de relação, enquanto Frankel (2012) argumenta que as maiores flutuações na demanda pela moeda são uma desvantagem para a condução da política monetária. 
sobre a moeda no cenário internacional são a ascensão do dólar americano sobre a libra esterlina como principal moeda mundial; a substituição do ouro como moeda de reserva internacional; a introdução do euro como moeda supranacional; o potencial de internacionalização do iene como consequência da força da economia japonesa na década de 1990; e as razões da crise do euro no final da década de 2000. O dólar americano, o euro, o iene, a libra esterlina; estas são todas moedas cujo governo emissor induz fracamente sua utilização. Como tal, ganhos obtidos por se internacionalizar segundo aspectos redistributivos têm pequeno impacto.

Entretanto, quando olhamos para países como China, Brasil, Índia ou Rússiaonde os governos locais trazem para si um forte controle da economia por meio da moeda nacional (compelindo em alto grau os agentes residentes a utilizarem-na) este efeito deve ser considerado com maior atenção. A utilização compulsória localmente de uma moeda nacional que não seja aceita internacionalmente implica incerteza sobre o preço de venda para os agentes nas operações comercializadas com o exterior. Como atualmente, as principais considerações relativas a políticas de internacionalização da moeda são relacionadas com as políticas chinesas de internacionalização do renminbi; os efeitos redistributivos ganham destaque e têm de ser então considerados ${ }^{2}$ A maior aceitação internacional de uma moeda pode reduzir o ônus distorsivo para os residentes advindos da indução da moeda nacional pelo governo local.

Neste ensaio, nós propomos que uma razão para um banco central internacionalizar a moeda é reduzir as distorções causadas na economia pela sua própria política de emissão de uma moeda nacional. A fim de sustentar este resultado, exploramos diversas questões ao longo das seções que se seguem a esta introdução.

Na seção 3.2, discutimos o relacionamento entre moedas e países e analisamos sua implicação sobre indivíduos e firmas. Primeiramente, na subseção 3.2.1, nós destacamos que o relacionamento entre um país e uma moeda não é um resultado natural e que sua adoção como hipótese recorrente na economia tem implicações normativas relevantes. $\mathrm{O}$ destaque dado a esta questão - observando que a adoção de uma moeda própria por um país é uma escolha política- é-nos fundamental e base para o raciocínio desenvolvido neste ensaio: o patrocínio governamental de moedas nacionais implica um resultado alocativo de renda diferente daquele que ocorreria na sua inexistência. As consequências sobre os agentes econômicos decorrentes desta hipótese são analisadas sobre agentes residentes e agentes não-residentes de forma individual, respectivamente nas subseções 3.2.2 e 3.2.3. Então, na subseção 3.2.4, consolidamos estas duas dimensões da aceitação de uma moeda pelos agentes de acordo com o poder estatal: domesticamente (residentes), quando há

2 Helleiner (2014) consolida as tentativas destes governos em internacionalizar suas moedas nacionais. Uma extensa literatura tem lidado com a internacionalização do renminbi. 
poder regulatório do estado, e internacionalmente(não-residentes), quando a aceitação de uma moeda está fora do alcance do poder normatizador do estado emissor.

Seguimos a discussão destacando as formas e implicações de um país induzir a moeda de emissão própria. Na seção 3.3, nós evidenciamos que um agente o qual busque avaliar precisamente seu patrimônio, ao utilizar como escala de medida uma determinada moeda para um conjunto de valores, procura mensurar seus demais valores nesta mesma unidade de conta. Este comportamento nos é relevante uma vez que explicita que a política governamental de induzir a utilização de uma determinada moeda impacta a escolha dos agentes em relação à moeda que eles utilizam como escala-referências importam e os governos as influenciam. Estabelecemos, pois, a dimensão do relacionamento entre moeda e residentes discutida na seção anterior, confirmando que não apenas o banimento de uma moeda estrangeira no território nacional tem consequências sobre a escolha dos agentes, como no caso chinês, mas que pequenas preferências introduzidas por um governo também as têm.

Na seção 3.4, mostramos que, num ambiente de indução monetária, a incerteza do valor da moeda estrangeira impacta a decisão de produção da firma. A moeda nacional, que é induzida pelo governo emissor, é utilizada pela firma como referência de unidade de conta. Considerando-se que esta moeda não seja utilizada internacionalmente, a firma terá de recorrer a uma outra moeda existente e que também seja aceita pelos agentes não-residentes nas vendas internacionais. $\mathrm{O}$ desconhecimento ex-ante sobre o valor da taxa de câmbio futura entre a moeda estrangeira e a moeda nacional confere incerteza à precificação da firma, que tem como referência a moeda local induzida por seu governo.

Na seção 3.5, exploramos os impactos sobre a decisão das firmas. Observamos a diversidade da função de produção dos diversos agentes distintos na economia, o que nos leva a concluir pelas consequências redistributivas da indução monetária de uma moeda não-internacional. Por fim, destacamos que os efeitos redistributivos são reduzidos ao se ter uma moeda que seja mais internacionalizada. Estabelecemos, portanto, a relação entre políticas de internacionalização da moeda e redistribuição de renda. A seção 3.6 conclui. 


\subsection{A restrição de uso de moedas estrangeiras e a internacionali- dade da moeda}

\subsubsection{O relacionamento biunívoco entre país e moeda}

Atualmente, a emissão de uma moeda nacional por um país é um evento usual. Não obstante, este relacionamento biunívoco entre uma moeda e um país está longe de ser um resultado obtido de uma maximização econômica, podendo ser percebido como um objetivo não-econômico que é perseguido por diversos países ${ }^{3}$. Kocherlakota e Krueger (1998) afirmaram que os países terem moedas nacionais poderia ser uma situação ótima. No modelo utilizado por eles, sugerem que a moeda é um instrumento de indicação privado da preferência do comprador sobre a origem das mercadorias e argumentam que os agentes valorizam mais bens locais do que bens estrangeiros. Como justificativa a esta hipótese, eles recorrem à falta de informações sobre as mercadorias estrangeiras e a maior dificuldade na execução de contratos transfronteiriços. No entanto, em um mundo em que existem cadeias globais de valor, esta não parece ser uma argumentação convincente. Não necessariamente informações de produtos locais estão mais facilmente disponíveis, nem contratos são feitos cumprir mais facilmente a nível nacional do que a nível internacional, principalmente se quiser se tomar esta afirmação válida para todos os países. A observação de qualquer viés no sentido de preferência por produtos locais parece ser resultado de outras variáveis, em vez de uma preferência incondicional por produtos locais (OBSTFELD; ROGOFF, 2000).

Não há nenhuma evidência que a relação biunívoca entre moeda e país seja maximizadora de renda. Se este relacionamento fosse ótimo, o território real dos países coincidiria com regiões monetárias ótimas, definida de acordo com os argumentos levantados pelo arcabouço da teoria de áreas monetárias ótimas (MUNDELL, 1961; MCKINNON, 1963; KENEN, 1969; ISHIYAMA, 1975). Assim, os países apresentariam um equilíbrio entre as condições especiais das áreas monetárias ótimas-mobilidades de fatores, nível de produção interna dos produtos comercializáveis e diversificação da produção local一; o que claramente não é o caso.

Ao invés disso, um país emitir uma determinada moeda nacional é uma escolha política. Tomar a relação biunívoca entre moeda e país como uma condição natural tem consequências relevantes sobre as conclusões; a adoção despercebida desta hipótese nos impede de identificar as consequências trazidas pela decisão política de uma país ter sua própria moeda. O ponto de referência analítica é distinto.

3 Bhagwati e Srinivasan (1969) sinstetizam a compreensão de objetivos não-econômicos para a teoria do comércio internacional. 
Duas dimensões surgem a partir da condição criada por uma moeda nacional em relação aos agentes econômicos. Quando relacionamos uma moeda a um determinado estado, a soberania interna é traduzida em soberania monetária e divide agentes entre residentes - que ficam sob o jugo das decisões do governo em relação à moeda- - não residentes - que podem considerar voluntariamente a moeda emitida como dinheiro ou não.

\subsubsection{A moeda nacional e os residentes}

Na dimensão que considera os agentes residentes, a decisão de um país ter sua própria moeda pode ser traduzida em o país (i) oficialmente conferir alguma preferência ao uso da moeda de sua própria emissão - significado este que está costumeiramente associado ao conceito de moeda de curso forçado (ou moeda de curso legal) ou a algum status nacional e (ii) restringir o uso de outras moedas que não sejam aquela de sua emissão. De forma contrária, se um país emite uma moeda mas não induz preferências impondo (i) ou (ii), esta emissão é similar a emissão de uma moeda privadamente, feita por algum agente relativamente confiável para os demais agentes utilizados da moeda. Efeitos deste último tipo de emissão não são objetivados aqui, onde focamos nas consequências introduzidas pela manifestação de soberania de um estado em conferir preferência a alguma moeda ${ }^{4}$. Em diferentes níveis, variando de país para país, o estado dar preferência a uma moeda é o que acontece.

Os impactos das preferências de um governo por uma moeda específica-(i) — foram observadas desde A Riqueza das Nações de Smith (1776, 122). Algum valor adicional para uma moeda é conferido pela escolha do governo em adotá-la. As formas de adoção destas preferências variam entretanto - a escolha de uma moeda como unidade de conta para a taxação do governo; a imposição de uma moeda como resolutória de dívidas; legislações do consumidor que obrigam que as vitrines mostrem preços em uma determinada unidade de conta; estes são todos exemplos de como esta preferência pode se manifestar.

Embora se possa considerar este efeito como exclusivamente marginal, a magnitude do efeito está correlacionada com a relevância das preferências concedidas a uma moeda. Quanto maior a preferência do governo, maior é o seu efeito. Quanto maior for o efeito, maior é o impacto sobre os agentes a ser considerado.

Esta noção de preferência é geralmente associada ao conceito de curso legal. Curso

4 Uma discussão ampliada, que inclua a existência de moedas emitidas por agentes não relacionados a governos, deve englobar o tema contemporâneo relacionado a moedas eletrônicas, tendo como exemplo destacado o bitcoin. Law Library of Congress (2014) apresenta um estudo sobre como diferentes governos limitam a escolha de seus residentes pelo uso do bitcoin, exemplificando uma possível ampliação de escopo do debate aqui realizado. 
legal é, no entanto, um conceito difuso, principalmente em economia, onde a sua compreensão varia de estudo para estudo (GOLDBERG, 2009). Estritamente, a definição legal para legal é o instrumento que, quando oferecido por um devedor para liquidação de uma dívida, libera o devedor de poder ser judicialmente acionado por não haver cumprido o pagamento da dívida. Se o credor se recusa a aceitar o instrumento que tem curso legal, ele não é mais capaz de litigar requerendo o seu pagamento (MCBRIDE, 2007).

Para além da discussão legal, a extensão das preferências normatizadas para uma moeda varia de país para país. Um país pode impor o status de resolutório de dívidas. Em alguns países, todas as notas e moedas têm curso legal. Por outro lado, em outros países, apenas algumas denominação das notas pode ter o status resolutório de dívida ou moedas serem resultarias de dívidas apenas até um limite de valor.

Um exemplo simples é um comprador que tem uma nota de valor elevado-digamos $\mathrm{R} \$ 100,00$. Ele pode pedir um café e ter o direito de liquidar seu débito trocando a sua nota de alto valor em denominações menores, transferindo ao vendedor algum custo de trocar o dinheiro em denominações menores, ou ele pode não ter este direito - o vendedor pode apenas recusar a nota de denominação alta como liquidante do débito. Neste caso, o comprador não tem condições de transferir seus custos de trocar sua nota por denominações menores. Ao invés disso, ele tem de recorrer a uma instituição financeira de forma a trocar seu dinheiro. Os impactos desta distribuição de direitos pode parecer de menor importância neste caso em um primeiro momento. Entretanto, assim como o desenvolvimento do protetor de joelhos para evitar que a poltrona da fileira que está a frente em um avião recline ${ }^{5}$, a distribuição de direito entre as pessoas faz diferença. $O$ governo determina o que tem curso legal e impõe o direito resolutório de dívidas.

A escolha da moeda em que os impostos devem ser pagos é um exemplo clássico de um governo introduzir uma preferência por um meio de pagamento. Os contribuintes também são compelidos, na maioria dos países, a relatarem sua renda em uma moeda específica. A escolha de diferentes taxas de câmbio irá produzir diferentes resultados de renda, então a preferência introduzida pelo governo pela seleção de uma unidade de conta importa para o resultado econômico. Outro exemplo são as inúmeras legislações de consumidor, as quais induzem preferências a uma moeda por obrigarem os varejistas a exporem seus preços um uma determinada unidade de conta - a moeda nacional.

A imposição de (ii) — a restrição ao uso de outras moedas que não a nacional — tem um impacto muito mais claro. Os agentes residentes são restringidos pelo poder legislador do país (soberania interna) a usar exclusivamente a moeda escolhida nacionalmente. $\mathrm{O}$ uso

5 Como referência sobre o exemplo utilizado, veja Associated Press (2014), que descreve o caso que originou intenso debate na imprensa. 
de moedas que não sejam a escolhida pelo governo é considerado ilegal e os residentes são compelidos a utilizá-la em suas interações econômicas, mesmo se eles preferissem utilizar uma outra moeda. Tomando uma firma exportadora como exemplo, se a moeda obtida como receita não coincidir com aquela utilizada para pagar suas despesas - salários são um bom exemplo, pois eles geralmente são em moeda local - riscos de câmbio e custos de transação são impostos ao agente ${ }^{6}$. Tomando-se dois agentes locais, eles podem preferir a manter moeda estrangeira como reserva de valor e, por conveniência, comercializar nesta moeda. tornar ilegal a posse de moeda estrangeira, tornar ilegal a realização de contratos em moeda estrangeira, e tornar ilegal o pagamento em moeda estrangeira são todas elas distúrbios nas preferências dos agentes. Quase a metade dos países limita o uso de moeda estrangeira por residentes (International Monetary Fund, 2015).

Um total de 88 países afirmaram ter algum tipo de restrição quanto ao uso de moedas estrangeiras por seus residentes (International Monetary Fund, 2015). A tabela 13 sintetiza as tipo de restrições mais comumente relatados pelos países. Diferentes arranjo locais existem e as restrições dificilmente podem ser dispostas em um espectro unidimensional. O uso obrigatório da moeda nacional pelos residentes é a legislação mais frequentemente observada. Entretanto, exceções proporcionadas a certas atividades ou a certas situações são também comuns, adicionando uma discriminação adicional entre os grupos de agentes. Embora frequentemente estas exceções sejam estipuladas em leis, alguns países também permitem que órgãos governamentais decidam discricionariamente caso a caso. Adicionalmente, como o exemplo da Namíbia, a moeda emitida pelo governo deve obrigatoriamente ser utilizada para efetuar pagamentos, embora os residentes sejam livres para escolher em qual moeda desejam firmar os contratos entre si.

Curiosamente, mesmo a compreensão dos limites do estado para regular soberanamente sobre as questões monetárias difere entre as declarações realizadas os países. Para o Suriname, apenas a definição de uma moeda de curso legal é suficiente para declarar isto como um controle cambial. A prática das preferências do tipo (i) é algo que a maioria dos países faz, mas que não declara como controle de câmbio. Por exemplo "a moeda da França ser o euro"- dificilmente alguém argumentaria que este é um controle de câmbio. Por outro lado, alguns países declaram que o uso obrigatório da moeda emitida pelo governo é uma consequência de tê-la como moeda de curso legal. Para outros, não existe tal relação: a Comissão Europeia define claramente o euro como a única moeda legal para os países participantes da zona do euro e nenhuma proibição para o uso de moedas estrangeiras surge desta regulamentação (European Comission, 1998).

Aqui, nós claramente distinguimos entre as práticas (i) e (ii), mas seu uso pelos

$6 \quad$ No caso de ocorrência de câmbio fixo entre as duas moedas, pode-se sempre pensar no risco cambial como a probabilidade de a paridade não ser mantida em um momento futuro. 
Tabela 13 - Restrições comumente impostas pelos países na escolha de moeda pelos residentes

\begin{tabular}{ll}
\hline Restrição imposta aos residentes & $\begin{array}{l}\text { País exem- } \\
\text { plo }\end{array}$ \\
\hline
\end{tabular}

O uso de moeda estrangeira não é permitido. Residentes são obrigados China, Brasil a utilizar a moeda emitida pelo governo.

O uso de moeda estrangeira não é permitido. Os residentes podem Zimbábue escolher entre algumas moedas pertencentes a uma cesta determinada pelo governo.

O uso de moeda estrangeira não é permitido. Exceções são definidas Rússia por lei.

O uso de moeda estrangeira não é permitido. Algumas exceções podem ser decididas por autoridades do governo caso a caso.

Ucrânia, Malásia

Os residentes podem contratar em moeda estrangeira, mas pagamentos Namíbia devem ser feitos na moeda emitida pelo governo.

Os residentes podem contratar em moeda estrangeira. Contratos que não tenham uma moeda especificada são considerados como denominados na moeda emitida pelo governo.

O uso de moeda estrangeira é permitido, porém regulado.

Afeganistão

Filipinas, Moçambique

governos é indistinto. Entretanto, ainda que o impacto das práticas (i) e (ii) difira em intensidade, seu impacto é em uma mesma direção e um espectro unidimensional pode ser uma aproximação justa para representar o conceito desde um governo não impor nenhuma preferência à moeda emitida por ele até um governo restringir todos os residentes a usarem a moeda auto-emitida e tornar ilegal o uso e a posse de moedas estrangeiras. A posição de uma moeda nesse espectro altera a intensidade do impacto sobre os agentes em decorrência das preferências; não a existência do impacto em decorrência da preferência conferida pelos governos. Quando o efeito redistributivo é forte, a introdução de uma política de internacionalização da moeda pode ter consequências significativas na distribuição de riqueza entre os residentes. Este é o caso que destacamos ao questionar sobre a moeda chinesa, por exemplo, e é o caso para o qual chamamos atenção neste ensaio.

\subsubsection{A moeda nacional e os não-residentes}

As preferências (i) e (ii) apresentadas na subseção anterior estão associadas à relação entre estados soberanos e seus residentes. Outra condição é o relacionamento que se apresenta entre a moeda emitida e os agentes não residentes no país emissor.

Os agentes não-residentes não estão sujeitos à imposição de aceitação da moeda 
emitida por um estado estrangeiro, por não serem alcançados por suas leis. Na seção anterior, relatamos as restrições impostas para a utilização de moedas entre dois agentes residentes. Por seu turno, quando a interação econômica ocorre entre um agente residente com um agente não-residente, os governos emissores têm sua possibilidade de restringir a escolha da moeda a ser utilizada na interação entre estes agentes limitada. Uma exceção comum às restrições impostas pelos governos sobre seus residentes no sentido de utilizarem a moeda nacional é na interação com agentes de outros países, quando os residentes podem escolher qual moeda utilizar. Da mesma forma, os agentes internacionais poderão escolher voluntariamente qual moeda aceitar. Assim, nas relações econômicas entre agentes residentes em diferentes países, a aceitação da moeda por eles estará condicionada ao reconhecimento individual sobre as diversas moedas disponíveis.

Grosso modo, existem dois tipos de moeda no cenário internacional-moedas globais e moeda locais. A diferença entre elas é o alcance das interações econômicas em que elas estão aptas a exercerem as funções da moeda. Moedas locais apresentam um alcance limitado. Elas são aceitas apenas em interações econômicas entre agentes residentes em uma mesma economia. Em oposição, moedas globais são aceitas em interações econômicas entre agentes de diferentes economias. As políticas de internacionalização da moeda, como o proposto anteriormente, são políticas governamentais que contribuem para tornar uma moeda local em moeda global.

O termo internacionalização sugere que uma moeda é levada de um nível a outro; de local para global. Em uma nomenclatura conforme, moedas globais também são chamadas de moedas internacionais enquanto moedas locais podem ser conhecidas por moedas não-internacionais.

Esta apresentação da dimensão internacional conduz a uma ideia dicotômica sobre a aceitação internacional de uma moeda. Nós destacamos no ensaio 1 que a aceitação das moedas não ocorre de forma dicotômica mas sim em um espectro de intensidade de aceitação. Não obstante, nosso principal objetivo aqui é compreender a distinção entre as consequências de uma moeda ser ou não aceita por agentes vivendo sob diferentes normatizações sobre a aceitação de uma moeda, para o que a consideração dicotômica se torna suficiente. Deixamos assim a discussão sobre as intensidades para um trabalho a parte. Aqui nós apenas a reconheceremos e, sempre que possível, avaliaremos exclusivamente o efeito limítrofe da aceitação ou não de uma moeda.

\subsubsection{Moeda e residência: indução da moeda e internacionalidade}

Nas subseções 3.2.2 e 3.2.3, analisamos individualmente as duas condições da moeda sob o ponto de vista dos agentes de acordo com o critério de residência. Agora partimos 
para relacionar estas duas características, que apresentamos esquematizadamente na figura 3 .

Figura 3 - Diagrama de interações econômicas entre residentes e não residentes e uso da moeda

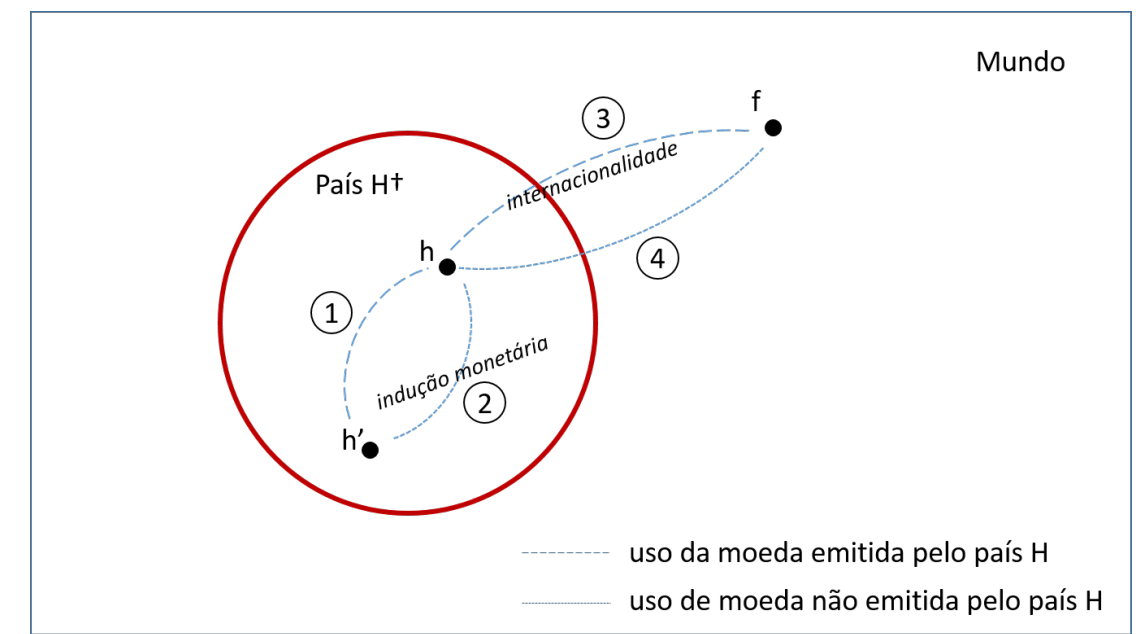

Nota: Representados dois agentes residentes no país $\mathrm{H}, h$ e $h^{\prime}$, e um agente não residente, $f$. Interações econômicas (1) e (3) ocorrem com o uso da moeda emitida pelo país H e interações (2) e (4) ocorrem com o uso de uma moeda não emitida pelo país H. A utilização da moeda estrangeira na interação (2) é analisada segundo uma política de indução da moeda, enquanto a utilização da moeda local na interação (3) é analisada segundo sua característica de internacionalidade. † Organização política detentora de soberania interna capaz de compelir seus residentes ao uso de uma moeda específica.

Nesta figura, representamos 3 agentes existentes no mundo $-h, h^{\prime}$ e $f-$ e o país $H$. Por simplicidade, o país $H$ emite sua própria moeda doméstica e, desta forma, o território do pais $H$ é coincidente com a área de jurisdição monetária de sua moeda, que está representado. Os agentes $h$ e $h^{\prime}$ são residentes no país $H$, enquanto $f$ é um não residente. Tomamos ainda a existência de uma moeda estrangeira. Os agentes podem interagir economicamente entre eles e as trocas de produtos podem ocorrer tendo uma das duas moedas como contrapartida. Assim, $h$ pode comercializar com $h^{\prime}$ e com $f$ utilizando ou a moeda emitida pelo país $H$, o que representamos pelos fluxos [1] e [3], ou a moeda estrangeira, o que representamos pelos fluxos [2] e [4].

Note que, como $h$ e $h^{\prime}$ estão sujeitos ao poder normatizador do país $H$, a capacidade de escolha entre [1] e [2] está integralmente sujeita às normas do país $H$ e o reconhecimento da moeda é forçado pelo país $H$ a ambos os agentes (moeda de curso forçado ou moeda legal). Em oposição, com a impossibilidade de o país $H$ criar obrigação para o agente $f$, as interações [3] e [4] não estão integralmente condicionadas à capacidade imposição do país $H$. Elas estão também condicionadas pela aceitação do agente $f$ das moedas utilizadas. 
Tomando então, de forma geral, a escolha da moeda a ser utilizada na interação entre dois agentes, podemos então dizer que a escolha da moeda está condicionada pelas restrições de escolha impostas pelo governo do país emissor e pelo grau de reconhecimento da moeda por um agente internacional. As restrições impostas pelo país, discutidas na subseção 3.2.2, chamamos de política de indução da moeda e as relacionamos ao grau de reconhecimento da moeda por agentes estrangeiros, discutido na subseção 3.2.3, que chamamos de internacionalidade. Ao variarmos a política de indução da moeda, alteramos a escolha de moeda nas interações entre residentes, enquanto que, ao variarmos o grau de internacionalidade da moeda, variamos a escolha de moeda nas interações entre residentes e não residentes.

Podemos representar as moedas existentes de acordo com estas duas dimenões. Na figura 4 nós as representamos em um gráfico bi-dimensional produzido com dois índices rudimentares, de forma que a avaliação de moedas neste espaço bidimensional não é apropriada, não obstante, o gráfico se mostra como um recurso adequado para esquematizar a ideia aqui discutida.

Figura 4 - As duas dimensões do relacionamento entre moeda e área emissora

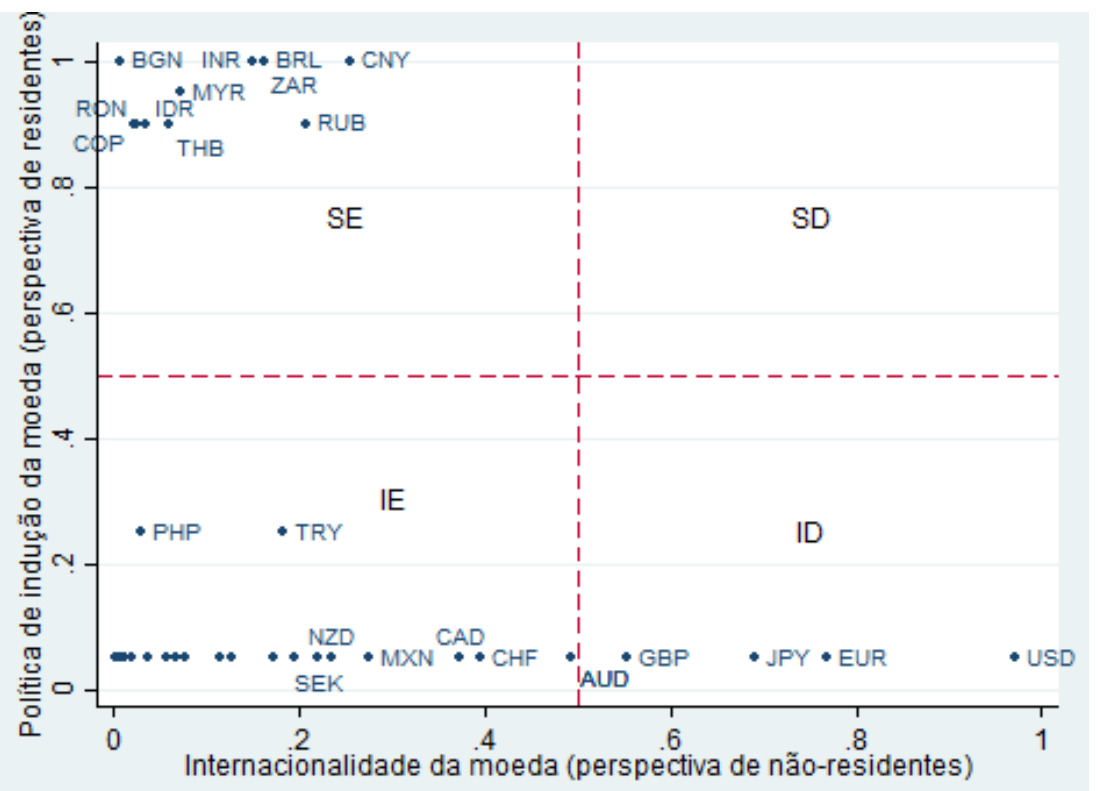

Nota: Esquema representativo de moedas segundo nível de sua indução pelo governo emissor e sua internacionalidade. Nível de indução segundo restrições declaradas por cada governo ao FMI e internacionalidade expressa segundo transformação logarítmica da participação da moeda nas operações de câmbio mundiais totais. Moedas selecionadas. Dados referentes ao ano de 2013. Quadrantes superior e inferior, e esquerda e direita (SE, SD, IE, ID) segundo composição de alta ou baixa indução da moeda; e de alta ou baixa internacionalidade. Fonte: International Monetary Fund (2015), Bank for International Settlements (2014).

No eixo vertical, representamos a interações entre o governo emissor e os residentes, construindo um índice para representar a política de indução da moeda nacional pelo 
governo do país. Nós calculamos o índice a partir dos dados do Relatório Anual de Arranjos de Câmbio e Restricões Cambiais do Fundo Monetário Internacional (International Monetary Fund, 2015) de forma a prever uma representação ordinal das restrições ao uso de moedas estrangeiras e preferências ao uso da moeda domesticamente induzida por cada país. No eixo horizontal, nós plotamos um índice de internacionalidade da moeda. Nós usamos como referência para o índice de internacionalidade a participação das moedas no total de operações de câmbio no mundo (Bank for International Settlements, 2014). Quatro quadrantes são definidos. Os quadrantes superiores (SE e SD) contém moedas cujo uso é induzido em alto grau, enquanto que o grau de indução é baixo nos quadrantes inferiores (IE e ID). Nos quadrantes à esquerda (SE e IE), o grau de internacionalidade é baixo, enquanto o oposto ocorre nos quadrantes à direita (SD e ID).

Nas seções 3.3 e 3.4, vamos argumentar que a indução de uma moeda nacional distorce a economia. Agentes com preferências de consumo e com tecnologias de produção distintas entre si e que são indiferentes segundo a origem e o destino dos produtos que comercializam têm seus padrões de consumo e de produção alterados quando são submetidos às restrições de um país que induz o uso de uma moeda específica; usualmente aquela que emitem. Por diversas razões, os governos destes países não desejam reduzir estas políticas de indução, o que traria suas moedas dos quadrantes superiores para os inferiores em nossa representação, e reduziria a redistribuição de renda causada por elas. Na seção 3.5, argumentaremos que a posição avaliada no sentido horizontal de nosso esquema também redistribui renda entre os agentes. As restrições de aceitação no sentido horizontal são em termos da internacionalidade da moeda. Para países que desejam manter uma política de restrição de uso de moedas estrangeiras por seus residentes, a redução do efeito redistributivo entre seus residentes pode ser uma adicional motivação para a adoção de políticas de internacionalização da moeda local.

\subsection{A moeda de referência}

Nesta seção, tratamos a questão de que um agente utiliza uma moeda como referência. De fato, ao dizermos "uma moeda", entendemos que o agente adota uma escala específica para mensurar valores e que uma moeda é uma escala apropriada para ser escolhida, destacando sua propriedade de unidade de conta. Nesta seção, nós mostramos que, desconsiderando-se demais fatores de influência, um agente tem preferência por utilizar uma única escala; uma única moeda. Assim, quando um governo induz o uso de uma moeda específica, ele também induz que ela seja utilizada como referência exclusiva de medida, vista a preferência pela utilização de uma única escala.

Usualmente em economia, nós assumimos que um agente utiliza uma moeda $a$ 
e então mostramos que a incerteza cambial decorrente da utilização de outra moeda $b$ o leva a preferir utilizar a moeda $a$ ou a buscar instrumentos financeiros de proteção cambial para evitar o descasamento entre ativos e passivos em moedas distintas. Esta é a estratégia que adotaremos posteriormente para discutir que esta escolha tem implicações na produção e que este impacto distribui renda. Nesta seção, argumentamos que a moeda $a$ é a escolhida como consequência da indução de uma moeda pelo governo. Poderíamos tentar utilizar fatores psicológicos e externalidades de redes para explicar o comportamento de um indivíduo e mostrar que ele prefere uma métrica de referência disponível ao adotar uma moeda como unidade de conta, o que deixamos para avanços futuros. Aqui, vamos nos utilizar da lógica contábil a que uma firma está submetida para mostrar que, uma vez que um governo defina regras para a contabilidade das firmas em relação à adoção de uma moeda, torna-se consequente a adoção desta moeda como referência para a firma. De forma mais geral, podemos entender regulação contábil como o estabelecimento da referência da unidade de medida.

Destacando a função de unidade de conta de uma moeda, nós concluiremos que os agentes elegem uma moeda a qual utilizam como referência: uma moeda de referência. Este comportamento é explicitado quando observamos os procedimentos contábeis de uma firma. As firmas desejam maximizar os lucros de seus acionistas, e, portanto, seu lucro contábil. Um dos princípios da contabilidade das empresas é a prudência. Este princípio significa "a adoção do menor valor para os componentes do ativo e do maior para os do passivo, sempre que se apresentarem alternativas igualmente válidas para a quantificação das mutações patrimoniais" (CFC, 1993, art. 10). A adoção da prudência implica a adoção de uma única moeda para registro dos fatos contábeis de uma firma. Alguns autores sugerem a adoção de uma única moeda como um princípio, ao que chamam de princípio do Denominador Comum Monetário (DCM) ${ }^{7}$, termo que utilizaremos para representar a adoção de uma única moeda como referência para a firma. Não tendo por objetivo discutir questões relacionadas à teoria contábil e seus princípios, focamo-nos na consequência da prudência para a escolha do moeda e temos que

Proposição 1 A adoção do princípio prudência por uma firma implica a adoção de uma única moeda para registro dos fatos contábeis (DCM).

Demonstração. Sejam $\beth$ um conjunto de fatos contábeis a serem registrados e $\aleph u$ um conjunto de registros representativos de $\beth$, cujos registros são denominados em uma única moeda. Por contradição, suponhamos que prudência não implique DCM. Logo, existe um conjunto $\aleph^{\prime}$, de registros representativos de $\beth$ que contenha ao menos um par de partidas

$\overline{7}$ Veja, por exemplo, Souza et al. (2011). 
cuja moeda de denominação difira da moeda de referência adotada para denominar todos os demais registros contábeis de $\aleph^{\prime}$ tal que o valor de ativos seja menor e o de passivos seja maior e este conjunto de registros mensure adequadamente o patrimônio da firma ${ }^{8}$.

Por simplicidade de compreensão, e sem perda de generalidade, fixemos a moeda nacional como a moeda utilizada primariamente para registros e uma moeda estrangeira como a moeda alternativa a ser utilizada. Adotemos que o sistema de câmbio que relaciona as moedas nacional e estrangeira é flutuante e representemos a taxa de câmbio de moeda nacional por moeda estrangeira seja representada por $e^{9}$. Sejam $A$ o valor do ativo; $P$ o valor do passivo; $S L$ a situação líquida da entidade; $\mathrm{E}(\cdot)$ o operador esperança e definamos $\alpha \in[0 ; 1]$ como o percentual de ativos mensurados em moeda estrangeira e $\beta \in[0,1]$ como o percentual dos passivos em moeda estrangeira. Temos então a relação

$$
(1-\alpha) \mathrm{A}+\alpha \mathrm{A} \cdot \mathrm{E}_{t}(e)-\left[(1-\beta) \mathrm{P}+\beta \mathrm{P} \cdot \mathrm{E}_{t}(e)\right]=\mathrm{SL}
$$

em que $\mathrm{E}_{t}(e)$ representa expectativa da taxa de câmbio pela qual se podem converter valores tidos em moeda estrangeira pelo valor em moeda nacional, que é usada como referência para a avaliação patrimonial da entidade ${ }^{10}$.

Definamos $p(e)$ como a função de densidade da probabilidade observada no instante do registro contábil $(t)$ em relação ao valor da taxa de câmbio e no momento da aviação patrimonial $(t+s), \operatorname{Pr}(e)$ como a sua função de distribuição cumulativa ${ }^{11}$ e $\dot{e}_{t}$ como o valor da taxa de câmbio em $t$. Seja $p_{a}$ a probabilidade de a taxa de câmbio $\dot{e}_{t}$ se apreciar entre o instante do registro contábil e da avaliação patrimonial $\left(p_{a}=\operatorname{Pr}\left(e>\dot{e}_{t}\right)\right)^{12} ; p_{d}$ como a probabilidade de depreciação de $\dot{e}_{t}\left(p_{d}=\operatorname{Pr}\left(e<\dot{e}_{t}\right)\right)$ e $p_{0}$ a probabilidade de a taxa se manter $\left(p_{0}=\operatorname{Pr}\left(e=\dot{e}_{t}\right)\right)^{13}$. Claramente, $\sum_{k \in\{0, a, d\}} p_{k}=1$ e, como estamos em câmbio flutuante, $p_{0}, p_{a}, p_{d} \in(0,1)$. Fixemos então a existência de pelo menos uma conta contábil com valor em moeda estrangeira no ativo da firma $(\alpha>0)$. Com $p_{a}>0$, temos que existe

8 Firma está associado ao conceito contábil de entidade. Aqui, mantemos o termos firma, mais usual na literatura econômica.

9 A adoção do sistema de câmbio flutuante como referência para a demonstração se explica pela intenção de a tornar mais intuitiva. A generalização da demonstração para o câmbio fixo pode ser concluída com a percepção de que a incerteza existente para os agentes é a probabilidade de o sistema de câmbio ser alterado ou o valor de paridade vir a ser alterado futuramente. Trata-se de uma tradicional explicação na literatura econômica que considera uma moeda comum um caso de extrema rigidez cambial.

10 Note que a utilização da avaliação da entidade com referência a uma única exclusiva moeda ao invés de uma cesta de moedas é uma hipótese que se explica pelo fato de a entidade estar constituída sob as leis de um dado país que adota tipicamente uma moeda para os registros e operações oficiais, conforme discutimos na subseção 3.2.2.

11 Para uma discussão sobre especificação da função densidade de probabilidade da taxa de câmbio, ver, por exemplo, Bank for International Settlements (1999) e Malz (1997).

12 Definimos a apreciação da taxa de câmbio do ponto de vista da moeda estrangeira: mais unidades da moeda nacional equivalem em um tempo futuro à mesma quantidade de moeda estrangeira que equivale a uma quantidade específica de moeda nacional no momento atual.

13 Observe que, com a restrição da taxa de câmbio ser avaliada a uma certa quantidade de casa decimais, $p_{0}=\operatorname{Pr}(e=\dot{e}) \neq 0$. 
um valor provável de $\dot{e}_{t+s}$ menor que $\dot{e}_{t}$ pelo qual o valor do ativo deve ser registrado, segundo o princípio da prudência. Fixe então $\ddot{e}<\dot{e}_{t}$. Por argumento semelhante, existe $\ddot{e}^{\prime}<\ddot{e}$, a qual deve ser utilizada para registro. Utilizando sucessivamente este raciocínio, concluímos que o valor do ativo em moeda estrangeira deve ser, no limite, avaliado pela adoção de $e_{t+s}=0$; o que faz com que o valor do ativo seja registrado pelo valor equivalente ao total originalmente denominado na moeda nacional. Por argumento análogo, o passivo será registrado por valor infinito.

Avaliemos então a confiabilidade do processo de mensuração para os diferentes valores de $\alpha$ e $\beta$. Com $\alpha \neq 0, \beta \neq 0$, observemos que registrar a parcela em moeda estrangeira do ativo por valor igual a zero e a parcela em moeda estrangeira do passivo por uma valor infinito produzirá uma situação líquida infinitamente negativa, o que não pode ser, de maneira razoável, considerado uma mensuração confiável do patrimônio da firma. Com $\alpha=0$ e $\beta \neq 0$, o resultado é idêntico ao anterior. Com $\alpha \neq 0$ e $\beta=0$, ainda que a situação líquida não tenha valor infinito, o valor do ativo em moeda estrangeira será registrado com valor zero. Ora, este patrimônio existe e, portanto, seu valor não deve ser avaliado como igual a zero.

Logo, uma situação líquida adicionada de um valor positivo infinitesimalmente pequeno é uma melhor representação do patrimônio da entidade do que a representação obtida com o registro do ativo em moeda estrangeira pelo valor zero, não podendo esta ser uma representação adequada. Temos então que nossa suposição é uma contradição: não existe $\aleph^{\prime}$ que represente $\beth$ e que atenda ao princípio da prudência.

Podemos interpretar o princípio da prudência como uma aversão ao risco de se ter um resultado contábil distinto daquele que é o observado. Vimos que como consequência de sua adoção, a firma denomina seus registros contábeis na mesma moeda que mensura o seu patrimônio. Como assumimos que o patrimônio é mensurado na moeda local, o que justificamos pela indução da moeda local pelo governo, os registros serão denominados nesta moeda local.

A indução por um governo de uma moeda para ser utilizada como referência, induz também que esta seja a moeda empregada pela firma. De outra maneira, podemos dizer que, caso a moeda induzida pelo governo seja diferente daquela que seria utilizada pela firma na ausência de restrições, a política de indução monetária altera a escolha da escala de mensuração de valor da firma. Certamente, devemos nos perguntar se a avaliação realizada com referência a uma única moeda faz sentido em um mundo cada vez mais integrado, no qual cadeias globais de valor passam a existir em um cenário de convivência de múltiplas unidades monetárias. Ao observarmos que em uma economia que não seja integralmente fechada e que tenha uma moeda que seja não-internacional, os residentes comercializarão 
com o exterior e terão débitos, ao menos parcialmente, em moeda estrangeira. Ora, mas neste caso nossa análise se torna ainda mais consistente. Ao estabelecer uma única moeda como unidade de mensuração do patrimônio, por exemplo, o governo impõe uma escala distinta daquela que seria utilizada pela firma. Na próxima seção, observaremos que a utilização de diferentes escalas de mensuração afeta o resultado da produção.

\subsection{Efeitos de uma moeda não ser aceita internacionalmente}

Na seção anterior, tendo considerado a política de indução da moeda discutida na seção 3.2, observamos que os agentes preferem comercializar com não-residentes em sua moeda local. Seguindo nossa argumentação formulada na subseção 3.2.3, a capacidade de um residente comercializar na sua moeda local com não-residentes será proporcional à quantidade de não-residentes que a reconhecem como moeda; será proporcional à internacionalidade desta moeda local. Na presente seção, analisaremos as consequências sobre a distribuição de renda de acordo este arranjo de indução da moeda e de sua correspondente internacionalidade.

\subsubsection{Interação econômica entre agentes residentes e não-residentes}

Fixemos a curva de oferta inversa $\left(s_{c_{h}}\right)$ do agente residente $u_{h} \in A_{h}$, em que $A_{h}$ é uma partição do mundo e que designa um país (o país corresponde a uma área monetária, tornando válida a relação biunívoca entre país e moeda, simplificando nossa análise). Assumimos $s_{c_{h}}^{\prime}(q)>0$. O subscrito de $s$ indica a moeda que é a unidade de medida para a curva de oferta, sendo $c_{h}$ a moeda emitida pelo país $A_{h}$. O agente residente $u_{h}$ utiliza $c_{h}$ como referência de valor. Para o residente, a indução da moeda nacional pelo governo de $A_{h}$ estabelece um ambiente doméstico em que a moeda $c_{h}$ é sua unidade de conta fundamental e as interações econômicas são tidas em dois planos: o doméstico e o internacional. No plano doméstico, o agente residente interage economicamente com outro agente residente, digamos $u_{h}^{\prime} \in A_{h}$, e todas as relações econômicas ocorrem por meio do uso da única moeda legal $c_{h}$. A existência e utilização de $c_{h}$ é justificada como solução para o problema da dupla coincidência de vontades (JEVONS, 1875) em uma economia com um número suficiente de bens para os quais a ocorrência de escambo teria um custo proibitivo (KIYOTAKI; WRIGHT, 1989; KIYOTAKI; WRIGHT, 1993). Ainda que seja induzida, os agentes residentes reconhecem e aceitam $c_{h}$ por suas funções, portanto, $c_{h}$ é considerada moeda e não ocorre demanda por substituição monetária, que ocorreria eventualmente de forma ilegal. $\mathrm{O}$ agente $u_{h}$ maximiza sua utilidade observando preços e sua disponibilidade de recursos usando a moeda $c_{h}$ como a sua unidade de conta de referência. Nós desenhamos $s(q)$ no gráfico de preços em moeda local $\left(P_{c_{h}}\right)$ e quantidade (q) no primeiro quadrante da figura 5. 
Seja $c_{f}$ uma moeda internacional não emitida por $A_{h}$. Nós assumimos que a lei do preço único é valida, exceto pela existência de custos cambiais. Esta hipótese é consistente com a evidência da validade da lei do preço único para uma mesma área monetária ${ }^{14}$ e com a redução de custos logísticos decorrente dos processos de globalização. Tomamos então exogenamente a relação entre $c_{h}$ e $c_{f}$, a qual indicamos por $\dot{e}$, e a representamos no segundo quadrante da figura 5. A relação è representa o nível teórico de mercado da paridade do poder de compra entre as duas moedas $c_{h}$ e $c_{f}$ sem a consideração dos custos de câmbio ${ }^{15}$. O terceiro quadrante apresenta o resultado da alteração de unidade da curva de oferta, passando-se do valor ofertado em $c_{h}$ ( $1^{\circ}$ quadrante) para o correspondente valor em $c_{f}$ a custo de fatores; os custos financeiros de conversão cambial não estão contemplados. Desenha-se $s_{c_{f}}$-a curva de oferta de $u_{h}$ na moeda $c_{f}$, a custo de fatores.

Figura 5 - Curva de oferta na moeda local e na moeda internacional

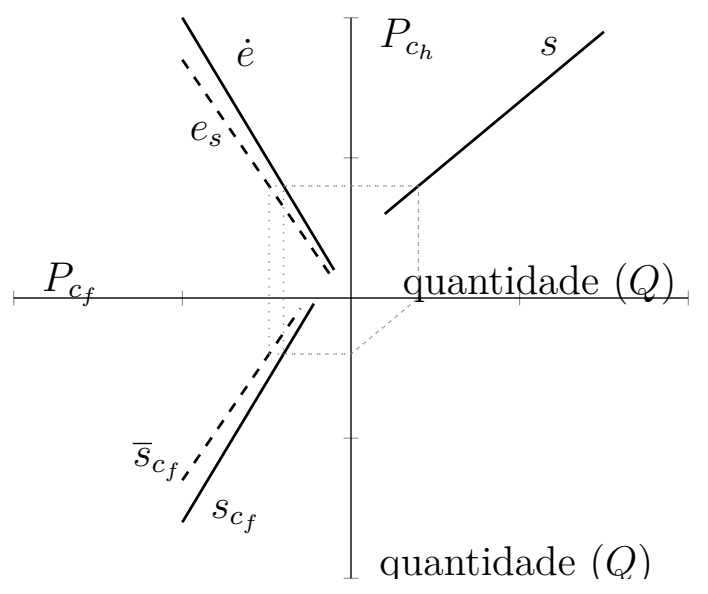

Na ausência de custos cambiais, as taxas de câmbio representariam exclusivamente a mudança na unidade de medida; preços denominados em diferentes moedas seriam equivalentes, de acordo com a relação $\dot{e}$. Entretanto, como há custos de conversão cambial, o nível da taxa de compra da moeda para o agente $u_{h}$ se desloca de $\dot{e}$ para $e_{s}$, representando a adição desse custo à taxa de câmbio. Representaremos o custo do câmbio por $k(q)>0$, sendo o custo adicionado a cada unidade $k^{\prime}(q)<0$ e $k^{\prime \prime}(q)>0^{16}$. Consequentemente, a função de oferta em moeda internacional observada está deslocada de $s_{c_{f}}$ para $\bar{s}_{c_{f}}$. Observe que os custos cambiais são fornecidos como função do montante cambiado, o qual é equivalente à receita de $u_{h}$. Considerando a adição dos custos de câmbio à oferta, a mesma quantidade é ofertada por um preço maior quando denominado em uma moeda

14 Para a avaliação da validade da lei do preço único para uma mesma área moentária com dados da União Europeia, veja Cavallo, Neiman e Rigobon (2014).

15 Cabe ressaltar que não objetivamos comparar o poder de compra entre cada uma das áreas monetárias, não se associando $\dot{e}$ diretamente ao conceito de taxa de câmbio real. Com a relação $\dot{e}$, nós destacamos a relação nominal entre as duas moedas $c_{h}$ e $c_{f}$, descontando o custo da operação cambial; custo que é o nosso elemento a ser analisado.

16 Com objetivo de simplificar a apresentação gráfica, os custos de câmbio, assim como as demais curvas, serão representados por retas ao longo deste ensaio. 
estrangeira. Em outras palavras, quando um agente oferta seu produto em uma moeda diferente daquela que ele utiliza como referência e ele se vê obrigado, em razão de sua moeda não ser internacionalmente aceita, a realizar uma operação de câmbio, a operação com um agente não-residente será ofertada a um preço maior.

Daqui em diante, nós apenas lidaremos com as curvas expressadas em preços na moeda internacional $\left(P_{c f}\right)$. Nós representamos o terceiro quadrante da figura 5 no primeiro quadrante da figura 6 . Na figura 6 , a curva de oferta do agente $u_{h}$ referenciada na moeda local (custos de fator, sem custos cambiais) é denominada na moeda estrangeira $\left(s_{c_{f}}\right)$. Sendo $p^{*}$ o preço no mercado internacional do item ofertado e $u_{h}$ tomador de preços do mercado internacional, o equilíbrio das vendas de $u_{h}$ para agentes não-residentes se dá no ponto $E$ e a receita das exportações esperada pelos agentes se torna equivalente à área $0 Q E B^{17}$.

Figura 6 - Efeitos dos custos cambiais na oferta

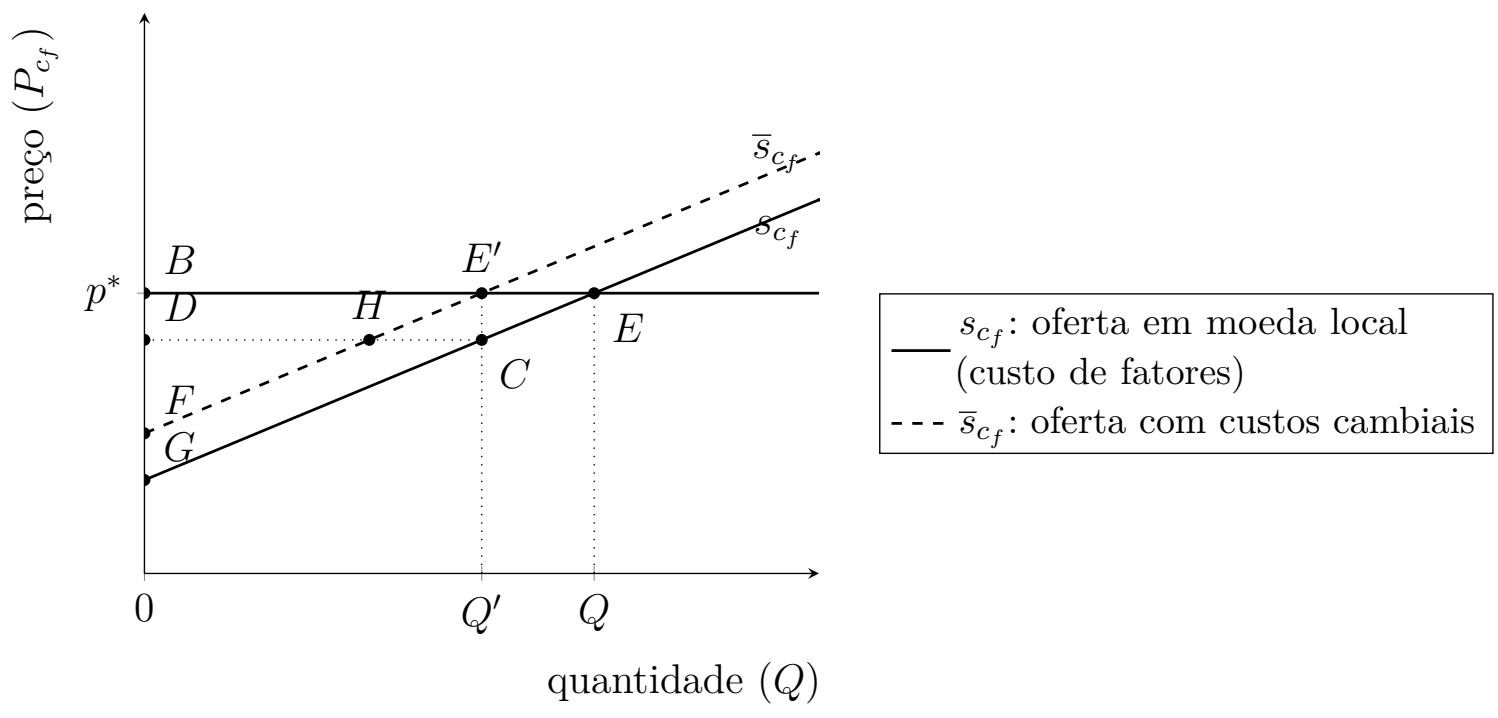

Quando consideramos os custos cambiais, $s_{c_{f}}$ se desloca para $\bar{s}_{c_{f}}$ e o novo equilíbrio está no ponto $E^{\prime}$. O total da quantidade exportada é reduzido de $Q$ para $Q^{\prime}$ e a receita total de exportação é então representada por $0 Q^{\prime} E^{\prime} B$. Entretanto, esta receita é agora repartida entre o agente exportador e o setor financeiro, o qual provê a transação de câmbio. O exportador retém a receita $0 Q^{\prime} C D$ enquanto paga $D C E^{\prime} B$ ao setor financeiro. Do deslocamento da curva de oferta, nós podemos concluir que

$\overline{17}$ Aqui podemos considerar o equilíbrio como o resultado do processo de barganha de uma única venda entre o vendedor residente e o comprador não-residente, que se encontram no mercado em um processo de matching, como descrito para a moeda em Kiyotaki e Wright (1993) e Matsuyama, Kiyotaki e Matsui (1993). Em razão da hipótese da firma tomadora de preços, este resultado é igualmente válido se considerarmos como demanda o conjunto de compradores não-residentes. Este mesmo arrazoado será válido para o residente comprador, caso que trataremos em seguida. 
Conclusão 3 Para um agente residente que não influencie preços no mercado internacional, a adição de custos cambiais à moeda nacional não-internacionalizada cujo uso é induzido pelo governo reduz o volume de comércio.

Uma importante interpretação surge da área $C E E^{\prime}$. Comparando ambos equilíbrioso do ponto $E^{\prime}$, com os custos cambiais, ao do ponto $E$, sem estes custos-, esta área representa, a partir do ponto de vista de $A_{h}$, a perda de excedente do produtor devido à redução do volume exportado. Esta diferença é originada do uso de diferentes moedas entre o país exportador - que tem a moeda $c_{h}$ induzida pelo governo - e o resto do mundo - onde os agentes não reconhecem $c_{h}$. Por outro lado, entretanto, pode-se argumentar que a escolha de se utilizar uma moeda nacional própria provê bem-estar para um país - desde ideia de nacionalidade até a possibilidade de um país ter uma política monetária independente. Deste argumento, um país se beneficia de usar sua própria moeda e a imposição do uso da moeda nacional aos agentes residentes faz com que eles enfrentem custos cambiais quando interagindo com agentes não-residentes. Então, a área $C E E^{\prime}$ representa a perda do agente $u_{h}$ decorrente da expectativa de ganhos de bem-estar por $A_{h}$ e é equivalente a

$$
p^{*}\left(Q-Q^{\prime}\right)-\int_{Q^{\prime}}^{Q} s(q) d q
$$

, em que $Q=s_{c_{f}}^{-1}\left(p^{*}\right)$ e $Q^{\prime}=\bar{s}_{c_{f}}^{-1}\left(p^{*}\right)$. Claramente, a política de preferência por uma moeda do país é um instrumento que altera o bem-estar dos agentes.

Outro aspecto a ser observado é o excedente do produtor. No equilíbrio a custos de fator, a área $E B G$ representa o excedente do agente, que é equivalente a $p^{*} Q-\int_{0}^{Q} s(q) d q$. Após considerar os custos cambiais, a quantidade de equilíbrio é reduzida de $Q$ para $Q^{\prime}$. A área $E^{\prime} B F$ representa então o excedente de venda sob custos cambiais. O excedente do produtor é mais baixo entretanto. Quando consideramos os custos cambiais, a receita é dividida ente o agente produtor e o setor financeiro, o qual provê a operação cambial. Com efeito, o pagamento que é feito ao setor financeiro é deduzido do excedente potencial do exportador. Então, a área $D C E^{\prime} B$ representa a receita do setor financeiro, enquanto a área $G C D$ é o excedente do produtor após considerados os custos cambiais, que é equivalente a

$$
\int_{0}^{Q^{\prime}}\left[s\left(Q^{\prime}\right)-s(q)\right] d q
$$

A receita transferida ao setor financeiro é equivalente a $\left[p^{*}-s\left(Q^{\prime}\right)\right] \cdot Q^{\prime}$ e seu excedente é deduzido dos custos cambiais, sendo representado por $Q^{\prime}\left[p^{*} \cdot s\left(Q^{\prime}\right)\right]-\int_{0}^{Q^{\prime}} k^{\prime}(q) d q$.

Conclusão 4 A política de preferência por uma moeda nacional:

(a) reduz o excedente do agente $u_{h}$ de $k^{\prime}\left(Q^{\prime}\right) \cdot Q-\int_{Q^{\prime}}^{Q} s(q) d q$; 
(b) transfere a receita $k^{\prime}\left(Q^{\prime}\right) \cdot Q^{\prime}$ de $u_{h}$ para o setor financeiro; e

(c) produz um gravame excessivo de $p^{*} \cdot\left(Q-Q^{\prime}\right)-\int_{Q^{\prime}}^{Q} s(q) d q$

em que $Q=s_{c_{f}}^{-1}\left(p^{*}\right)$ e $Q^{\prime}=\bar{s}_{c_{f}}^{-1}\left(p^{*}\right)$.

Observe que, para cada agente pertencente ao país $A_{h}$, a limitação imposta pelo governo por dar preferências a uma moeda nacional não-internacional induz a uma área $C E E^{\prime}$ de valor não-negativo $\left(C E E^{\prime} \geq 0, \forall x_{h} \in A_{h}\right)$. Como $A_{h}$ não está em uma condição de autarquia, nós esperamos que ocorra pelo menos uma interação econômica entre um residente e um não residente. Então, a agregação de $C E E^{\prime}$ pelos agentes residentes em $A_{j}$ é positiva $\left(\sum_{u_{i} \in A_{h}} C E E^{\prime}>0\right)$, significando que o país perde excedente das exportações devido à política de indução de uma moeda.

Então, a área $C E E^{\prime}$ é a representação do trade-off do país entre se beneficiar de ter sua própria moeda e se beneficiar do comércio internacional, na perspectiva do agente residente. Quanto maior for a área de trade-off de bem-estar, maiores são os custos para os agentes residentes nas interações econômicas com agentes não residentes devido à emissão de uma moeda local. Em adição ao efeito de produção do gravame excessivo, se a instituição financeira que provê a transação cambial não é residente, os custos cambiais-que em um ambiente internacionalizado integrariam o excedente do produtos - também são enviados ao exterior, significando uma perda suplementar numa visão nacionalista.

Efeitos similares são observados quando o agente residente é o comprador e a venda é realizada por firmas não residentes. Na figura 7, nós traçamos a curva de demanda e o deslocamento do preço de $p^{*}$ para o seu valor com o uso induzido de uma moeda não-internacional, mantendo-se a hipótese de nem a quantidade comprada por $u_{h}$, nem o total comprado pelos conjunto de agentes residentes em $A_{h}$, alterar os preços no mercado internacional.

A adição de custos cambiais, desloca o preço de equilíbrio $p^{*}$ para $p^{*}+k^{\prime}(q)$. O preço iguala a demanda inversa interna $d(q)$ e então o equilíbrio interno ocorre em $E^{\prime \prime}$. A quantidade é reduzida de $Q$ para $Q^{\prime \prime}$.

Conclusão 5 A existência de custos cambiais para moedas não-internacionais induzidas internamente inibe o consumo doméstico. 
Figura 7 - Efeitos dos custos cambiais na demanda

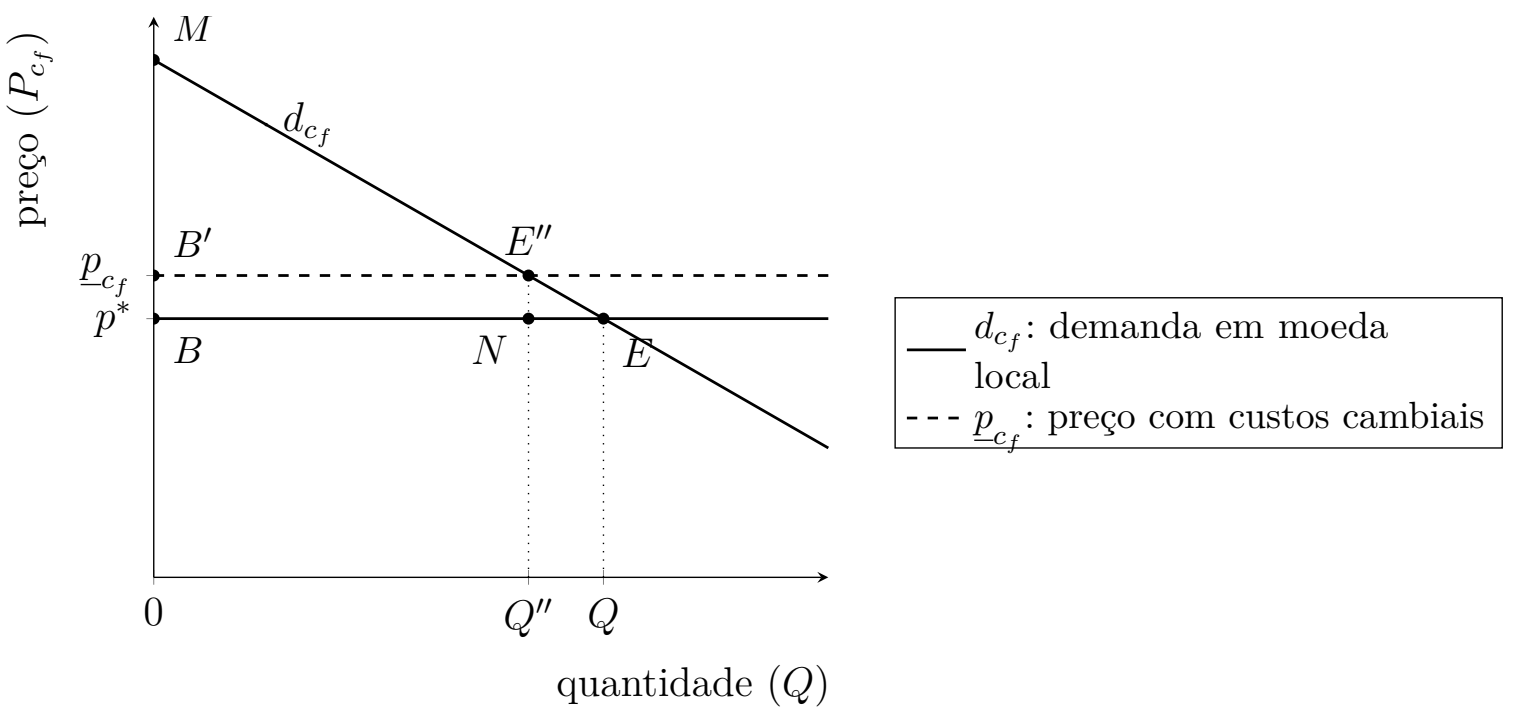

Observe que as conclusões 3 e 5 nos permitem afirmar que, do ponto de vista comercial, a indução de uma moeda não-internacional é similar à imposição de barreiras comerciais para os agentes residentes.

Ao tratarmos os efeitos redistributivos sobre os excedentes, temos que:

Conclusão 6 Considerando as consequências redistributivas da política de indução da moeda, o excedente do consumidor interno é (a) reduzido de EBM para $E^{\prime \prime} B^{\prime} M$ de

$$
\int_{0}^{Q^{\prime \prime}} k^{\prime}(q) d q+\left[\int_{Q^{\prime \prime}}^{Q} d_{c_{f}}(q) d q-\left[Q-Q^{\prime \prime}\right] p^{*}\right]
$$

em que $Q=d_{c_{f}}^{-1}\left(p^{*}\right)$ e $d\left(Q^{\prime \prime}\right)-k^{\prime}\left(Q^{\prime \prime}\right)=p^{*}$. A primeira parcela da adição representa $(b)$ o excedente do consumidor que é transferido para o setor financeiro e a segunda parcela, (c) o gravame excessivo que é gerado da não-internacionalidade.

Observe também que tanto neste caso como no caso anterior de oferta interna, nenhuma hipótese adicional foi feita sobre o local de residência do provedor da transação cambial. Assim, na perspectiva nacional de um país, ou o excedente pode ser redistribuído internamente, ou transferido para o exterior. Não nos ocuparemos desta questão aqui, uma vez que nos concentramos em destacar a existência do efeito redistributivo a paritr da política de indução de uma moeda não-internacional e suas implicações, mantendo-nos indiferentes sobre considerações de ganhos segundo perspectivas nacionalistas. 


\subsubsection{Interação econômica entre residentes}

Efeitos redistributivos oriundos da moeda local não-internacional induzida pelo governo não são limitados a interações econômicas entre residentes e não residentes apresentadas na subseção anterior. Para as interações econômicas entre os residentes, podemos ver a política de indução da moeda nacional como uma tarifa imposta ao comércio efetuado com os residentes no exterior.

No caso em que há indução da moeda, os custos cambiais que lhe são próprios recaem sobre as operações que ocorrem com agentes não residentes. Entretanto, diferentemente de uma tarifa sobre o comércio em que o montante arrecadado é uma receita do governo, no caso da moeda induzida, a receita é transferida para o setor financeiro e os ganhos do governo podem ser considerados em termos da obtenção de independência da sua política monetária. Desta forma, a existência de uma moeda nacional pode ser entendida como uma tarifa cujo fato gerador é a existência de interação de agente residente com outro agente não-residente e cuja finalidade é perseguir objetivos "econômicos nacionais".

Na figura 8, nós traçamos o ambiente doméstico agregado, com os preços em uma moeda internacional no eixo vertical e quantidades no eixo horizontal. Representamos a demanda doméstica agregada denominada em moeda estrangeira internacional $\left(D D_{c_{f}}\right)$ e a oferta doméstica agregada $\left(S S_{c_{f}}\right)$. Assumindo livre comércio e sem limitações de fronteira para a moeda, o equilíbrio é tido em $E$, em que a oferta a custos de fatores se iguala à demanda interna e ao equilíbrio de $\operatorname{preços}^{18}$.

Prosseguimos então com a hipótese das firmas tomadoras de preços, agora representadas no plano agregado pela hipótese do "país pequeno". Ao incluirmos a contabilização dos custos da moeda do país (moeda não-internacional e alto grau de indução pelo governo), os preços no mercado doméstico, em que os agentes estão sujeitos às restrições impostas pelo governo, adicionam custos cambiais. Os preços internos são então maiores que aqueles encontrados no equilíbrio decorrente dos mercado sem restrições. Os compradores passam a encontrar um preço maior para as compras importadas e os exportadores passam a ofertar no mercado externo a um preço superior àquele existente no mercado internacional.

Excluímos de nossa discussão bens não-comercializáveis, cuja existência não pode ser explicada em nosso arranjo. Como os agentes estão espacialmente concentrados, as razões pelas quais o comércio aconteceria entre uns agentes, mas não aconteceria entre outros, exige restrições adicionais, como controles alfandegários. Partindo do referencial

18 Por simplicidade para a construção do gráfico, partimos de uma análise em que as demanda e oferta domésticas do país emissor da moeda nacional não-internacional se igualam. Na ausência de demais restrições que impliquem preferência por um mercado nacional, não há nenhuma outra razão para que isto ocorra. A análise não sofreira alterações em relação à redistribuição de renda, caso fossem assumidos excesso de oferta ou de demanda para o referido país. 
Figura 8 - Efeitos de moedas não-internacionais no equilíbrio do mercado interno

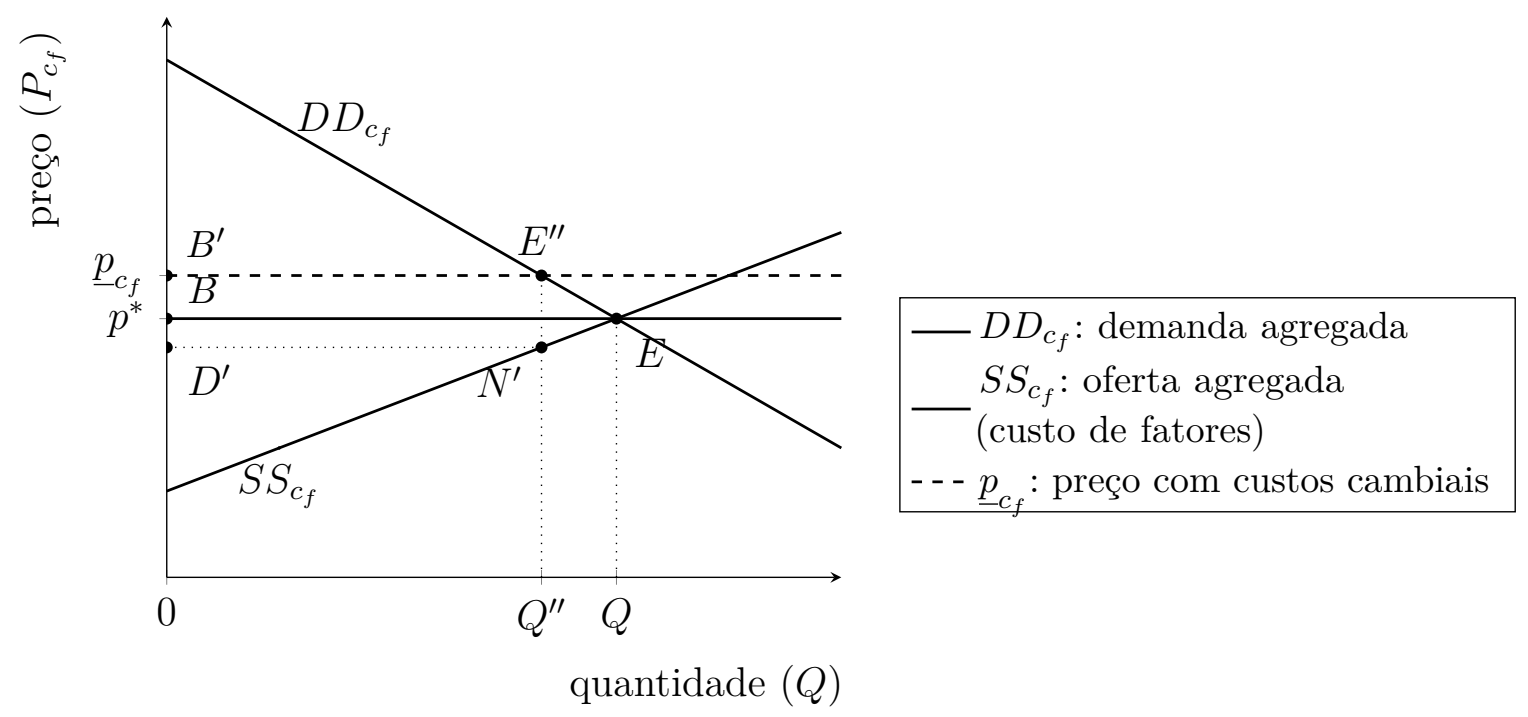

de um mundo globalizado, as limitações tendem a desaparecer. Um médico nos Estados Unidos é atualmente capaz de realizar uma cirurgia remotamente em um paciente que está na Europa, por exemplo (MARESCAUX et al., 2002). Serviços mais simples podem também ser providos remotamente na medida que a tecnologia avance e os custos de provimento a longa distância sejam reduzidos. Com efeito, no comércio internacional, a globalização pode ser vista como um processo de transformar bens não-comercializáveis em bens comercializáveis.

Ademais, a condição de bem não-comercializável é uma categorização que se adequa especialmente à contabilidade fundada em bases nacionais. Para esta categorização, nós também assumimos que as interações transfronteiriças de bens ou serviços definidos como não-comercializáveis ocorrem em uma magnitude significativamente menor que as interações dentro das fronteiras de um país. O simples exemplo de agentes presentes nas linhas de fronteira elucida esta questão. Em adição à restrição pela qual se define um país, não há nenhuma razão para agregar serviços entre agentes nacionais e não o fazer entre agentes em diferentes lados de uma fronteira.

Feitas estas considerações, apresentamos então, na figura 8, a adição de custos cambiais deslocando o preço do produto estrangeiro no mercado interno de $p^{*}$ para $\bar{p}_{c_{h}}$. Ainda, com a elevação do preço de sua produção no exterior, os produtores residentes passam a ofertar somente para o mercado interno. Para os produtores domésticos, um preço de venda $p \in\left[p^{*}, \bar{p}_{c_{f}}\right]$ proporcionará um resultado em que a oferta doméstica atenderá a demanda doméstica.

Observe que, caso o mercado doméstico se configure como concorrência perfeita, o 
efeito da indução monetária será segregar os mercados internacionais e doméstico para o produto específico. Caso os produtos produzidos por todas as firmas do setor sejam idênticos, nenhuma implicação econômica adicional será consequente deste efeito segregador. Entretanto, devemos considerar que existem setores para os quais isto não é uma boa representação.

Vamos nos concentrar no caso em que existem poucas firmas no mercado doméstico. Podemos então relacionar a situação com indução monetária à limitação do mercado doméstico e compará-la com a situação de livre-mercado anterior. Com indução monetária e poucas firmas, passamos a uma economia nacional num mundo de Chamberlain (1933) e Robinson (1933) em competição monopolística. Pelos resultados de Dixit e Stiglitz (1977) e de Krugman (1980a) para uma economia fechada sabemos que esta será uma situação de menor eficiência ${ }^{19}$. Seguimos, assim, adotando o caso em que o poder de mercado dos agentes residentes permitem que eles definam preço para o mercado local. Podendo definir preços e considerando que a perda de excesso do produtor pela redução de produção seja inferior à transferência de excedente do consumidor para o produtor em decorrência do aumento de preços - condição que se tornará preceptível na análise a seguir-, o produtor definirá o maior preço para o qual se mantenha a segregação de mercados, sendo este infinitesimalmente próximo do preço $\bar{p}_{c_{f}}$, digamos $\underline{p}_{c_{f}}{ }^{20}$. Este preço $\underline{p}_{c_{f}}$ se iguala à demanda inversa interna $D D$ e então o equilíbrio interno ocorre em $E^{\prime \prime}$. A quantidade consumida é reduzida de $Q$ para $Q^{\prime \prime}$.

Conclusão $7 \mathrm{Na}$ ausência de barreiras ao comércio exterior, a existência de custos de câmbio sob uma política de indução da moeda inibe a produção interna.

Mais uma vez, nós observamos alterações nos excedentes do consumidor e do produtor e a formação de gravame excessivo. O excedente do produtor do agente $u_{h}$ é alterado de $E B G\left(p^{*} Q-\int_{0}^{Q} s(Q) d q\right)$ para $G N E^{\prime} B\left(p^{*} Q^{\prime \prime}-\int_{0}^{Q^{\prime \prime}} s(q) d q+\int_{0}^{Q^{\prime \prime}} k^{\prime}(q) d q\right)$ de $p^{*}\left(Q-Q^{\prime \prime}\right)-\int_{Q^{\prime \prime}}^{Q} s(q) d q-\int_{0}^{Q^{\prime \prime}} k^{\prime}(q) d q$. O excedente do consumidor interno é reduzido de $E B M$ para $E^{\prime} B^{\prime} M$ de $p^{*}\left(Q-Q^{\prime \prime}\right)-\int_{Q^{\prime \prime}}^{Q} s(q) d q-\int_{0}^{Q^{\prime \prime}} k^{\prime}(q) d q$. O gravame excessivo decorrente da não-internacionalidade da moeda é representado pela área $N E E^{\prime}$ equivalente a $\int_{Q^{\prime \prime}}^{Q}\left[d_{c_{f}}(q)-s_{c_{f}}(q)\right] d q$

19 Note, entretanto, que a explicação de Krugman (1980a) para o comércio entre países não é aplicável na nossa análise. Aqui, consideramos a existência de custos para o comércio entre residentes e não-residentes - com efeito, trata-se do nosso objeto principal.

20 Caso os produtores no mercado doméstico adotem o preço $\bar{p}_{c_{f}}$, os consumidores passam a ser indiferentes entre consumirem produtos produzidos no mercado doméstico e no mercado internacional. Este caso não pode ser um equilíbrio, pois os produtores, sob os custos da moeda não-internacional, vendem a um preço maior no mercado internacional como o discutido na subseção anterior e, portanto, vendem apenas para o parte do mercado doméstico. 
Em decorrência da não-internacionalidade da moeda, os consumidores transferem para o produtor interno o excedente $B N^{\prime} E^{\prime} B^{\prime}$ equivalente a $\int_{o}^{Q^{\prime \prime}} k^{\prime}(q) d q$. Desta forma, o produtor interno se apropria dos custos cambiais quando vendendo para outros agentes residentes. Em suma, temos

Conclusão 8 Nas interações internas em um país, a política de indução da moeda:

(a) reduz o excedente do consumidor em $p^{*}\left(Q-Q^{\prime \prime}\right)-\int_{Q^{\prime \prime}}^{Q} s(q) d q-\int_{0}^{Q^{\prime \prime}} k^{\prime}(q) d q$;

(b) transfere o excedente $\int_{0}^{Q^{\prime \prime}} k^{\prime}(q) d q$ do consumidor para o produtor;

(c) produz um gravame excessivo de $\int_{Q^{\prime \prime}}^{Q}\left[d_{c_{f}}(q)-s_{c_{f}}(q)\right] d q$.

\subsubsection{Discussão}

Até aqui, nós identificamos três efeitos principais que surgem dos custos de transação cambial decorrentes do uso de uma moeda estrangeira por um agente residente quando interage com agentes não residentes: (1) a redução do volume total de comércio, que implica um trade-off de bem-estar entre os excedentes de comércio internacional e a emissão de uma moeda nacional própria; (2) transferências de renda-dos comerciantes para o setor financeiro, que é dividido entre os custos cambiais e o excedente do setor de câmbio, ou entre os comerciantes no caso doméstico-; e (3) um gravame excessivo devido à política cambial. Tratando-se de uma análise fundamentada na adição de custos cambiais, nós poderíamos ser levados a considerar que nossa análise se confunde com as considerações acerca destes custos já consideradas nas ponderações sobre vantagens e desvantagens de ser ter uma moeda internacional. Não é este o caso, entretanto.

A análise tradicional está concentrada na associação da maior internacionalidade de uma moeda como uma redução de custos, permitindo que os agentes residentes tenham acesso a custos mais baixos ao comercializarem com o exterior de forma uniforme entre eles. (SWOBODA, 1968, 6), ao elencar "tarifas de corretagem cambial, tarifas bancárias, custos contábeis e inconveniência psicológica, entre outros", está concentrado nas diferenças existentes entre residentes e não-residentes como função do uso de uma moeda e de seu nível de internacionalidade. O tratamento dos ganhos ou perdas para os agentes residentes no país emissor da moeda em função de sua internacionalidade podem ainda ser vistos, por exemplo, na síntese feita por Papaioannou e Portes (2008) em relação ao euro e também na conveniência para os agentes destacada por Frankel (2012), que é considerada ocorrer de maneira uniforme entre eles. 
Nossa análise, por outro lado, desenvolveu-se sobre a redistribuição de renda entre os agentes residentes num país como consequência da política de indução da moeda. Se análises anteriores são os custos entre residentes e não-residentes que estão em foco, nesta análise a redistribuição de renda consequente da política governamental tem o destaque. A relevância deste nível microeconômico para a análise da internacionalidade da moeda já havia sido sugerida por Cohen (2012). Na análise dele, entretanto, os ganhos dos residentes "vêm principalmente às custas de agentes no exterior, em vez de agentes domésticos" (COHEN, 2012, 16) ${ }^{21}$ e sugere que o ganho líquido para o país emissor seria claramente positivo. Em consonância com o que já apresentamos anteriormente, temos de discordar de sua análise microeconômica. Quando argumenta que a maior internacionalidade vem às custas principalmente de agentes não residentes, Cohen (2012) toma a moeda nacional como uma situação definitiva. Ao ressaltarmos que a emissão e a indução de uma moeda nacional são decisões políticas, tivemos como consequência uma situação de redistribuição de renda entre residentes. Na próxima seção, destacaremos que esta redistribuição pode ser novamente alterada como consequência da internacionalidade da moeda. Entre os agentes residentes, os efeitos domésticos serão novamente realocativos.

\subsection{Internacionalidade e redistribuição}

Trataremos inicialmente o efeito da internacionalidade da moeda como uma questão de custos sobre o agente residente. Tomemos um exemplo conforme o descrito na figura 9. Nela, o agente residente no país $A_{h}$ tem seus custos completamente referenciados na sua moeda nacional, seguindo a hipótese de indução da moeda local, e vende para um agente não residente. Primeiramente, vamos supor que o comprador (não-residente) reconheça a moeda nacional do agente residente como passível de exercer para ele as funções de uma moeda, significando, no caso, que ele a aceita como um meio de troca. Neste caso, os únicos custos que recairão sobe o exportador serão os custos da ordem de pagamento. Com um grau suficiente de internacionalização financeira, os instrumentos de pagamento são providos internacionalmente de forma competitiva e seus custos podem ser assumidos como não significativamente diferentes de um instrumento de pagamento disponível domesticamente. Portanto, os efeitos do custo de transações cambiais sobre os agentes residentes não são percebidos para moedas locais internacionalizadas. A curva de oferta do agente residente será $\bar{s}_{c_{h}}$, independentemente da característica de residência do comprador.

Para moedas não-internacionais, entretanto, os custos decorrentes de se denominar os produtos exportados na moeda local fazem diferença. Sem assumir um poder de barganha

21 Tradução livre do autor do trecho original em inglês: The gains of "winners" come mainly at the expense of actors abroad rather than at home. 
Figura 9 - Curvas de oferta em diferentes níveis

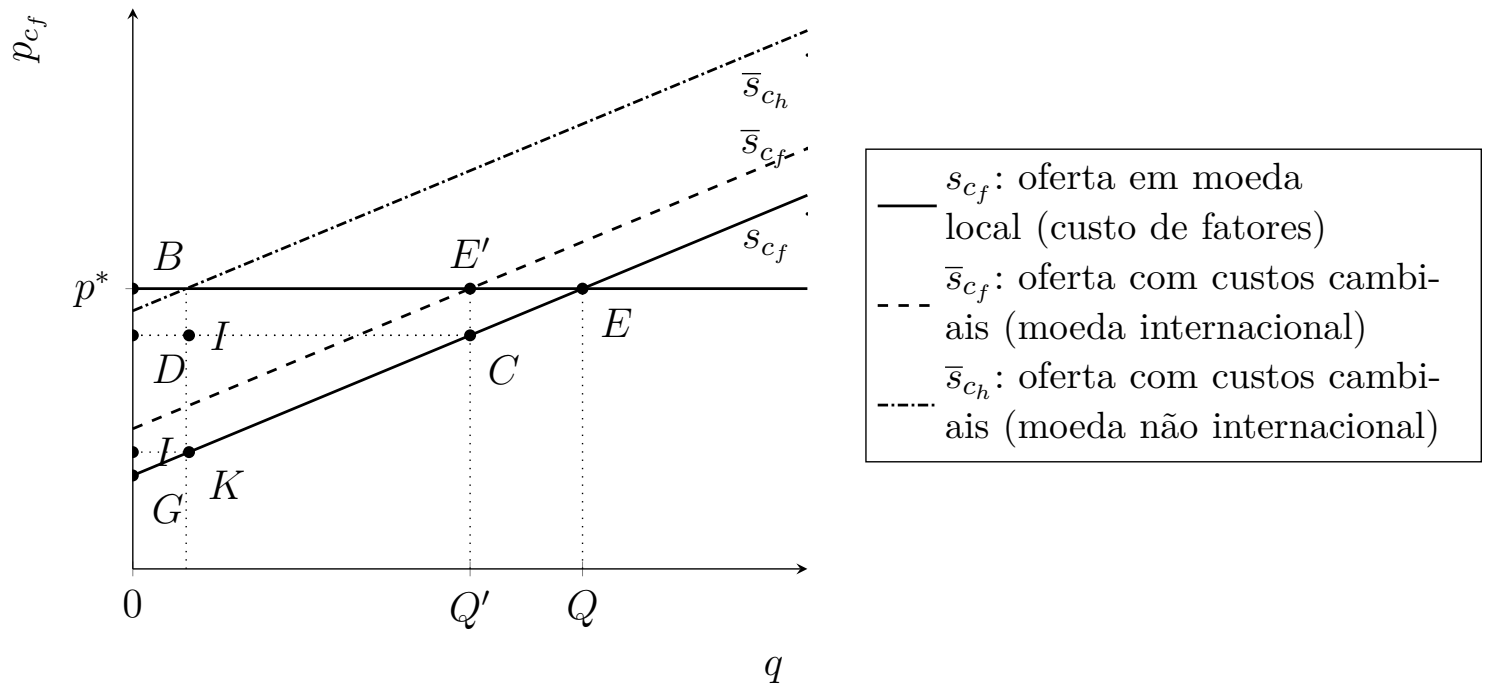

completo para o exportador - o qual não seria consistente com a hipótese de tomador de preços e está em consonância com as evidências empíricas (ITO et al., 2012) e os mais recentes progressos teóricos (GOLDBERG; TILLE, 2013) - a função de oferta de exportações do agente é deslocada para a esquerda quando considerados os custos cambiais comparados aos custos da moeda local do exportador. Como os custos de se lidar com uma moeda não-internacional no mercado internacional são indiscutivelmente maiores, nós podemos assumir a ocorrência de um substancial deslocamento para a esquerda na curva de oferta do agente.

Sendo a moeda $c_{h}$ a moeda de utilização induzida em $A_{h}$, nós esperamos que a estrutura de custos do agente seja referenciada em $c_{h}$ e, consequentemente, também a curva de oferta da firma o seja. Se a firma pretende vender no mercado internacional, ela fatura seus produtos na moeda $c_{f}$ em razão de $c_{h}$ não ser uma moeda internacional. Se a moeda local fosse internacional, $\bar{s}_{c_{f}}$ e $s_{c_{h}}$ coincidiriam e as posições relativas entre $\bar{s}_{c_{f}}$ e $\bar{s}_{c_{h}}$ estariam condicionadas à cesta de moedas em que a estrutura de custos estaria denominada ao invés de ter de recorrer a outras moedas em razão da restrição de liquidez. Entretanto, não ser uma moeda internacional faz $\bar{s}_{c_{f}}$ estar à direita de $\bar{s}_{c_{h}}$, mesmo quando a estrutura de custos está integralmente denominada em $c_{h}$.

Associamos assim, no ambiente de uma moeda localmente induzida pelo goveno, a percepção dos custos da moeda induzida em uma situação de alta e de baixa internacionalidade $^{22}$. Quando agentes não-residentes não aceitam utilizar a moeda $c_{h}$, os agentes residentes são levados a utilizar uma outra moeda $\left(c_{f}\right)$, que é diferente daquela a qual $\overline{22}$ O ensaio 1 se ocupou em discutir com maiores detalhes a característica de internacionalidade da moeda. 
eles são induzidos a utilizar domesticamente e, consequentemente, têm como referência de mensuração para sua produção. Esta impossibilidade de escolha causa os efeitos observados na seção anterior.

A menos que consideremos, por hipótese, que todas as firmas de uma economia tenham uma função de produção similar em termos do que é vendido no mercado doméstico e no mercado internacional - o que está longe de ser uma simplificação razoável para o caso que discutimos - as diferentes firmas sofrem distintos impactos sobre sua produção como consequência da política de indução da moeda. Assim, podemos destacar que os efeitos que tratamos ocorrem nas vendas para o exterior ou compras oriundas do exterior exclusivamente; ela não ocorre nas transações comerciais domésticas, quando ambos os agentes são induzidos a utilizar a mesma moeda emitida nacionalmente. $\mathrm{Na}$ ótica dos produtores nacionais, a não aceitação da moeda induzida nacionalmente por potenciais compradores que não são sujeitos às normas do governo local altera os custos de produção e, assim, os resultados de vendas entre residentes e não-residentes, consequente da possibilidade de utilização de $c_{h}$ ou de $c_{f}$. Na ótica dos consumidores nacionais, efeito similar ocorre na escolha de compra de produtos entre vendedores residentes e não-residentes. Temos então que o impacto da moeda não-internacional cuja utilização é induzida aos residentes é observado de forma distinta entre as vendas domésticas e as vendas internacionais. Quanto mais uma firma estiver propensa a vender para o exterior, mais lhe será impactante a não aceitação de sua moeda nacional pelo comprador de seu produto.

Relembramos que a internacionalidade de uma moeda significa que os agentes não-residentes estão dispostos a aceitar $c_{h}$ como moeda para as interações com os agentes residentes. Neste caso, quando as vendas puderem ser determinadas na moeda do vendedor - seja pela costumeira hipótese da denominação na moeda do exportador, seja pela probabilidade positiva do faturamento na moeda do exportador decorrente do poder de barganha (GOLDBERG; TILLE, 2013)—há um menor impacto da política de indução da moeda e, assim, seguindo a associação entre as dimiensões de restrição doméstica (indução da moeda) e de restrição internacional (internacionalidade da moeda) estabelecida na subseção 3.2.4, podemos concluir que

Conclusão 9 A maior internacionalidade da moeda reduz os efeitos redistributivos causados pela política de indução de uma moeda emitida nacionalmente. 


\subsection{Comentários finais}

Neste ensaio, nós propusemos um novo argumento para a consideração de políticas de internacionalização da moeda: a redistribuição de renda entre os agentes residentes. Ao notarmos que a existência de uma moeda nacional não é um resultado exclusivamente econômico, mas uma decisão política, pudemos considerar que a alteração do grau de internacionalidade de uma moeda por uma política não necessariamente é um desvio de uma economia de um país de uma solução de eficiência econômica para uma situação com distorções causadas por uma política. Abrimos espaço para que uma política de internacionalização da moeda seja percebida como um instrumento que altera a distribuição de renda e que ela possa, eventualmente, conduzir a uma situação de menores distorções.

Não é demais destacar o que não foi escopo deste ensaio: nossa conclusão não é no sentido de prescrever uma política de internacionalização da moeda para um governo. Uma conclusão como esta requereria considerações dos diversos custos e benefícios relacionados a este tipo de política - algo que está presente na literatura econômica associado a diversas moedas e países - , bem como requereria também a escolha de uma perspectiva específicaseja ela nacionalista ou cosmopolita. Neste ensaio, introduzimos a questão da redistribuição de renda como argumento adicional para esta avaliação.

Este novo argumento tem interesse especial para países que induzem fortemente a moeda que emitem. Nestes países, como o Brasil e como a China, a indução da moeda nacional é feita em nível elevado, com o banimento do uso de moedas estrangeiras em suas territórios inclusive. Nestes casos, a redistribuição de renda decorrente da indução monetária parece ser relevante.

Se, entre os agentes residentes, a escolha de uso de moedas é restrita pela normativação do governos, a restrição de uso nas interações entre residentes e não-residentes é dada pela internacionalidade da moeda. Para os agentes, reduzir as distorções causadas pela impossibilidade de uso local de uma moeda estrangeira pode se dar pela possibilidade de uso internacional da moeda local. Esta é a nossa contribuição.

A partir deste ponto de vista, novos estudos parecem se tornar imediatos. Como sugestão de avanços futuros permanecem a estimativa quantitativa do efeito de redistribuição de renda decorrente da indução monetária; a estimação de uma função de utilidade social para descrever a adoção da política de indução monetária por um país e a modelagem economica que explicite endogenamente o surgimento da moeda nas interações entre os agentes e que considere as restrições governamentais de indução da moeda. 
Parte IV

Ensaio 4 


\section{Lidando com a disponibilidade de instru- mentos financeiros: uma experiência inci- piente de internacionalização da moeda no Brasil}

\subsection{Introdução}

Uma relativamente extensa literatura tem lidado com a inovação em instrumentos financeiros, a qual é normalmente vista como resposta aos diferentes problemas oriundos dos processos econômicos de otimização (TUFANO, 2003). A inovação financeira está longe de ser um processo recente (WEBER, 2009); trata-se de um processo usual que remonta aos primórdios da história econômica. Se, por um lado, as pesquisas acadêmicas mais recentes se preocupam principalmente com derivativos e regulação financeira (INSTEFJORD, 2005; BOS; KOLARI; LAMOEN, 2013; ZARUTSKIE, 2013; CALLUZZO; DONG, 2015), por outro, os meios de pagamentos de varejo têm sido trazidos para o centro das discussões em decorrência de reflexões sobre políticas que tenham em consideração a eficiência e solidez dos sistemas financeiros nacionais (BIS, 2012).

Desde 2008, os bancos centrais de Argentina e Brasil operam conjuntamente um sistema de pagamentos que têm provido uma ordem de pagamento original, a qual é chamada de SML (acrônimo de Sistema de Pagamentos em Moeda Local). O que torna esta ordem de pagamento singular é o fato de os bancos centrais proverem eles mesmos uma operação de câmbio associada à operação de pagamento principal. A partir da perspectiva dos usuários - remetente e destinatário-, torna-se uma ordem de pagamento que é, ao mesmo tempo, paga pelo remetente em sua moeda nacional e recebida pelo destinatário, já convertida, em sua própria moeda nacional.

Até o presente, todas as pesquisas discutiram o SML a partir de um ponto de vista de integração regional ou de facilitação do comércio. Baumann e Mussi (2011), ao tratarem de cooperação monetária e financeira em uma comparação entre os casos asiático e latino-americano, aninham o SML com os demais acordos monetários e financeiros regionais. Em especial, o então recente SML é observado como um desenvolvimento do Convênio de Pagamentos e Créditos Recíprocos (CCR), firmado no âmbito da Aladi, o qual utiliza a moeda norte-americana para as liquidações de comércio. Vê-se o SML como um instrumento que permite o comércio ser realizado nas moedas nacionais. Biancareli (2011) 
incrementa a percepção de relação entre os dois sistemas, destacando-se portanto sua percepção do fim comercial do SML, e apresenta este como uma resposta aos problemas do CCR. (TRUCCO, 2012) adiciona, ao contraste entre estes dois sistemas, o sistema de compensações comerciais da Aliança Bolivariana das Américas, conhecido por Sucre (do acrônimo do nome original em espanhol Sistema Único de Compensación Regional). Em uma busca por novos paradigmas de desenvolvimento regional, este autor apresenta o SML como um meio de libertação do comércio regional em relação à dependência do dólar americano. Ressalta, entretanto, que o sistema não atinge este objetivo plenamente, uma vez que se utiliza da moeda americana para a compensação entre os bancos centrais. Em uma análise mais focada no impacto de custos de transação no comércio, Reiss (2013) sugere que, com a adoção do sistema, a redução de custos cambiais e os ganhos de eficiência com a integração dos sistemas de pagamentos nacionais no âmbito do Mercosul poderiam estimular o comércio entre os países do bloco. É neste mesmo viés comercial que os próprios bancos centrais envolvidos apresentam e divulgam o sistema (Central Bank of Brazil, 2012; Banco Central de la República Argentina, 2014). Ainda que historicamente os bancos centrais latino-americanos tenham operacionalizado mecanismos de compensações para o comércio nacional $^{1}$, avaliar as políticas da autoridade monetária exclusivamente pela via comercial impede a compreensão dos impactos sobre a estabilidade do poder de compra da moeda.

Neste ensaio, o Sistema de Pagamentos em Moeda Local (SML) é avaliado como uma política pública orientada a eliminar restrições às escolhas dos agentes econômicos. Como consequência da insuficiente disponibilidade de instrumentos financeiros que permitam determinadas operações internacionais na moeda local, os agentes econômicos são conduzidos à opção de uma outra moeda que não a moeda local. Por exemplo, a inexistência de instrumentos de hedge entre a moeda local de um exportador e a de um importador pode os conduzir à utilização de uma moeda estrangeira para faturarem suas operações, impactando na transmissão de choques no valor desta moeda veículo para as economias locais. Ademais, a insipiência de um mercado cambial que permita a realização de uma remessa financeira diretamente entre duas moedas leva os agentes a recorrerem a uma moeda veículo, transferindo renda do setor produtivo para o setor financeiro. Claramente, o comércio não está excluído de nossa análise. Mas, nela, ele é apenas o pano de fundo, enquanto o raciocínio sobre as questões financeiras é o que conduz nossa exploração a respeito do SML.

Esta alteração de interpretação tem relevante impacto sobre a compreensão do

1 São exemplos o CCR e o Sucre, assim como os acordos de swap cambial entre o Banco Central do Brasil e o Banco Central da China (Banco Central do Brasil, 2013) e entre este e o Banco Central da Argentina (Banco Central de la República Argentina; People's Bank of China, 2014) e acordos de comércio entre Brasil e Bulgária, Hungria, Polônia e Romênia. 
sistema de pagamentos como política adotada. Discutir uma interpretação monetária para o sistema possibilita que sejam destacados os impactos sobre discussões macroeconômicas relevantes; impactos cuja percepção desvanece quando o comércio internacional toma o papel principal nas discussões. Neste sentido, as consequências de se lidar com restrições aos fluxos cambiais ganham destaque.

No contexto das discussões econômicas latino-americanas, nunca é demais reiterar que a discussão sobre o SML não trata sobre da conveniência de se obrigar um agente residente a utilizar a moeda nacional nas operações comerciais - o que indiscutivelmente teria alto potencial de adicionar ineficiências à economia. Em oposição franca a este ideário, trata-se da avaliação da conveniência de se prover um sistema que permita aos agentes escolherem qual moeda lhes é conveniente utilizar, eliminada a restrição de liquidez existente no mercado de câmbio entre as moedas locais.

Este ensaio é organizado em 5 seções. Após esta introdução, descrevemos o sistema de pagamentos na seção 4.2. Na seção 4.4, em um ambiente em que os agentes são induzidos a utilizar a moeda nacional que possui baixa internacionalidade, argumentamos que a incerteza de preços impacta a decisão de produção dos agentes. Na seção 4.5, nós discutimos a predileção pela adoção do SML como política para lidar com esta consequência. Sustentamos que o sistema adotado por Argentina e Brasil é uma forma menos onerosa de se adotar uma política com a finalidade de lidar com as consequências da política de indução de uma moeda nacional. A seção 4.6 conclui.

\subsection{O sistema de pagamentos}

\subsubsection{Contexto de adoção do sistema}

As ordens de pagamento SML têm-se tornado comuns entre os países do Mercosul, bloco que respaldou a política de instituição do sistema (MERCOSUL, 2007). Brasil e Argentina foram os primeiros instituidores, lançando o sistema entre os dois países para uso em operações comerciais em outubro de 2008. É a partir desta experiência, que está há mais tempo em operação, que desenvolveremos nossa análise. Brasil e Uruguai iniciaram a operação de um SML em dezembro de 2014, depois de terem firmado uma carta de intenções ainda em 2009 (Banco Central do Brasil; Banco Central del Uruguay, 2012), e Argentina e Uruguai assinaram uma carta de intenções em 2012 para estabelecerem um SML entre os dois países (Banco Central de la República Argentina; Banco Central del Uruguay, 2012), não havendo este ainda entrado em operação.

Ainda que a lógica comercial tenha sido a estratégia adotada pelo banco central brasileiro para a divulgação do sistema, a autorização legislativa que lho permite ope- 
racionalizar foi consignada em um instrumento legal que promoveu três institutos que contribuem para a viabilização de um papel internacional para o real: a Lei $\mathrm{n}^{\circ} 11.803$, de 2008 (BRASIL, 2008). Os três preceitos previstos nesta lei-e sintetizados na tabela 14 - são: (i) a permissão de o Banco Central do Brasil (BCB) manter contas de depósito em reais de bancos centrais estrangeiros e de demais instituições estrangeiras que prestem serviços de compensação, liquidação ou custódia; (ii) a permissão a instituições financeiras brasileiras que executassem ordem de pagamento em reais recebidas de instituições financeiras estrangeiras, dando cumprimento a transferências internacionais de reais (TIR) entre contas de titularidade diferentes ; e (iii) a autorização para o BCB abrir a linha de crédito à Argentina necessária à operacionalização do SML.

Tabela 14 - Medidas de internacionalização do real da Lei 11.803

\begin{tabular}{ll}
\hline Medida adotada & $\begin{array}{l}\text { Dimensão de } \\
\text { internacionalização }\end{array}$ \\
\hline $\begin{array}{l}\text { SML, TIR, autorização para contas de reserva de outros } \\
\text { bancos centrais no BCB e outras instituições financeiras }\end{array}$ & Meio de troca \\
$\begin{array}{l}\text { Autorização para contas de reserva de outros bancos centrais } \\
\text { no BCB }\end{array}$ & Reserva de valor \\
SML (exigência de faturamento na moeda do exportador) & Unidade de conta \\
\hline
\end{tabular}

A manutenção de contas de bancos centrais estrangeiros viabiliza a utilização do BRL como reserva de valor no âmbito público oficial, permitindo que governos mantenham suas contas em reais junto a seu correspondente brasileiro. Logicamente, a previsão de existência destas contas não implica a constituição delas, mas a não existência desta previsão limita a sua possibilidade de ocorrência. Outra opção para os governos estrangeiros seria a manutenção de contas em reais via instituições financeiras privadas tal como manteriam demais agentes privados, o que também foi tratado no instrumento normativo. Neste âmbito, as instituições financeiras que prestam serviços de compensação, liquidação ou custódia passaram a estar autorizadas a manter contas diretamente no BCB e não mais estando obrigadas a manter estas contas em instituições financeiras brasileiras.

A autorização para instituições financeiras locais cumprirem ordens de pagamentos em reais oriundas do exterior incrementa a possibilidade de uso do BRL no exterior. Assim, instituições financeiras não residentes passaram a poder enviar ordens de pagamento de seus clientes para destinatários residentes no Brasil. Abriu-se assim, uma possibilidade de oferta de serviços em BRL. A transferência financeira da moeda brasileira entre residentes e não residentes no Brasil teve um grande revés no meio da década de 1990 em decorrência de escândalos relacionados a lavagem de dinheiro por meio das contas então regulamentadas 
para não residentes, conhecidas por contas CC5 ${ }^{2}$. Assim, o incremento de possibilidades de efetivação de transações em BRL entre residentes e não residentes representa não apenas um avanço do sentido de se permitir uma maior internacionalização, como também um desvanecimento, na década seguinte, da resistência a operações financeiras desta natureza que foi causada pelos escândalos anteriores.

Assim, se não houve oficialmente uma política de internacionalização da moeda, medidas que permitiriam acrescentar características de internacionalidade ao real foram adotadas de forma conjunta em um dado momento, flexibilizando as rígidas restrições à movimentação de capitais e acesso estrangeiro à moeda brasileira. Deste conjunto de medidas legalmente adotadas se pode depreender uma ação do legislador em adotar em certa medida uma estratégia de internacionalização para a moeda, o que se confirma quando se analisa o relatório de discussão parlamentar (Comissão Mista Parlamentar, 2008).

Neste ensaio as avaliações de política pública serão realizadas com referência ao Brasil e avaliamos exclusivamente o SML brasileiro. Entendemos que as discussões são suficientemente genéricas para se aplicarem, mutatis mutandis, a qualquer país que empregue um sistema similar. As diferenças em relação à Argentina serão apontadas quando disponíveis, assim como os impactos sobre as conclusões. Na próxima subseção, nós descrevemos o SML tanto do ponto de vista de seus usuários, como do ponto de vista interno de sua operacionalização. A partir desta visão interna, a relevância da concessão legal de crédito se tornará mais clara, assim como sua indispensabilidade de acordo com o desenho operacional feito para o mecanismo.

\subsection{A descrição do sistema}

\subsubsection{Perspectiva para os usuários: uma ordem de pagamento com câmbio associado}

Descrevemos nesta subseção o SML de acordo com a visão externa ao sistema, seguindo a estratégia apresentada em Reiss (2013). Podemos entender uma operação comercial internacional como possível de ser dividida em diversas etapas, compreendendo, por exemplo, o acordo comercial e o embarque da mercadoria. Os sistemas de pagamentos regionais latino-americanos historicamente tratam de todas estas fases, enquanto o SML, contrariamente, trata apenas da remessa financeira envolvida. Desta forma, assemelha-se a uma ordem de pagamento comum ofertada por instituições financeiras privadas, seja

2 Os escândalos de lavagem de dinheiro envolvendo o uso das contas CC5 foi registrado, por exemplo, por Dellasoppa (2004) e Matias-Pereira (2013), enquanto a mecânica de remessas em reais entre residentes e não residentes foi descrita por Muniz (1999). 
para remessas financeiras entre residentes em um mesmo país, seja para a remessa entre residentes em países distintos.

Entretanto, o que diferencia a ordem de pagamento do SML das demais é a capacidade de causar uma percepção virtual nos comerciantes de eles operarem em suas moedas locais, sem a necessidade de uma operação de câmbio. Isto ocorre em decorrência de os bancos centrais ofertarem esta operação câmbio internamente ao sistema, realizandoa diretamente entre as autoridades monetárias. Assim, o remetente paga a ordem de pagamento à sua instituição financeira em sua moeda local e a instituição financeira paga ao seu respectivo banco central na mesma moeda do país. No país do destinatário, todos os pagamentos (à instituição financeira e ao destinatários) são feitos na moeda local do país de destino. A conversão cambial promovida internamente ao sistema pelos bancos centrais elimina a existência de uma operação de câmbio privada e, assim, do ponto de vista dos usuários, cada parte residente em uma país opera exclusivamente na sua moeda nacional.

A figura 10 representa este fluxo, exemplificando uma remessa do Brasil (onde as transferências financeiras são em BRL) para a Argentina (onde as transferências financeiras são em ARS). O remetente registra a ordem de pagamento em uma instituição financeira em seu país e paga por ela na moeda local [1]. A sua instituição financeira paga nesta mesma moeda por esta ordem de pagamento ao sistema [2], representado pelo banco central de seu país. O sistema, por meio do banco central contra-parte da operação, paga à instituição financeira do destinatário a ordem de pagamento já na outra moeda [3], enquanto esta instituição financeira paga ao destinatário nesta mesma moeda local [4].

Figura 10 - Ordem de pagamento SML-visão dos usuários

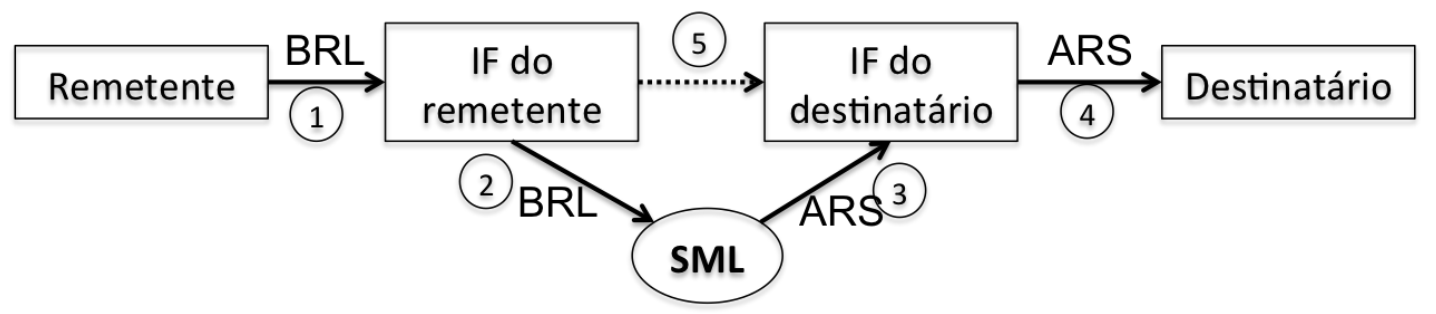

Para os agentes que fazem a transferência de recursos, simula-se uma ordem de pagamentos como as demais ordens de pagamentos usualmente disponíveis, seja localmente, seja internacionalmente em que há uma operação de câmbio associada. Tal qual qualquer sistema de pagamentos, o SML se torna nada mais que a interligação entre dois sistemas de pagamentos nacionais - é o meio pelo qual cursam as ordens de pagamento. A diferenciação do SML está em o remetente pagar em uma moeda e o destinatário receber em outra, sem que tenha sido contratada uma operação de câmbio específica. A precepção da ordem de pagamento sendo remetida em uma moeda e sendo recebida em outra é representada pela 
linha pontilhada[5], que proporciona a ideia de um serviço de transferência direta entre a conta dos dois usuários envolvidos.

A percepção de uma operação financiera em que o câmbio se torna um acontecimento secundário é relevante de duas formas. Primeiramente, contribuiu para uma percepção de uma integração financeira e monetária virtual. Serviços financeiros se tornam disponíveis e o uso de moedas distintas passa a ser menos perceptível entre os dois países. Em segundo lugar, que é o argumento enfocado neste trabalho, assumindo que existe pelo menos um custo de informação sobre uma moeda que não sejam as locais, a percepção de operar nas moedas locais permite que os agentes possam fazer suas escolhas de precificação na moeda em que lhes é mais familiar: na moeda local em que são induzidos pelo governo a operar. Isto altera a relação existente entre os custos envolvidos na produção.

Feitas estas considerações sobre o câmbio de denominação dos valores, cabe então compreender o valor pelo qual é feito este câmbio de moedas ofertado pelos bancos centrais. Em uma ordem de pagamento tradicional, o remetente instrui uma instituição financeira a fazer um pagamento de um determinado valor fixado a um destinatário específico. No caso de remessas financeiras em que estejam envolvidas mais de uma moeda, a ordem não necessariamente é fixada no valor a ser recebido pelo destinatário. Por exemplo, o valor da operação pode ser fixado na moeda do remetente e o valor recebido pelo destinatário é resultado da conversão cambial deste valor originalmente contratado, podendo a taxa de câmbio ser contratada no momento de instrução do pagamento ou uma taxa a ser conhecida em um momento futuro (BIS, 2007). No SML, no momento em que a ordem de pagamento é registrada, o valor que será recebido pelo destinatário é conhecido, mas o valor que é pago pela instituição financeira ao sistema não está definido, sendo assim um sistema de pagamentos variável-fixo ${ }^{3}$. O valor a ser recebido pelo destinatário é fixado e denominado em sua moeda, enquanto o valor a ser efetivamente pago pelo remetente será conhecido apenas posteriormente, de acordo com a taxa de câmbio divulgada pelo sistema ${ }^{4}$.

Assim, o destinatário da ordem de pagamento (exportador) recebe o exato valor

3 Grosso modo, os sistemas de remessas de dinheiro podem ser divididos em quatro tipos, tendo em vista a fixação, ou não, do valor pago pelo remetente e recebido pelo destinatário no momento em que a ordem é contratada. No sistema fixo-variável, e o valor a ser pago pelo remetente é fixado no momento do contrato da operação; o valor a ser pago ao destinatário é conhecido posteriormente. No sistema variável-fixo; em que o valor a ser pego ao destinatário da operação é fixado no momento do contrato da operação, mas o valor a ser pago pelo remetente é conhecido posteriormente. No sistema fixo-fixo, ambos os valores pago pelo remetente e a ser pago ao destinatário são fixados no momento de contratação da operação. E no sistema variável-variável, ambos os valores pago pelo remetente e a ser pago ao destinatário são conhecidos após a contratação da operação, sendo a operação contratado com referência a um outro montante.

4 Apresentaremos o cálculo do valor da taxa de câmbio entre as duas moedas nacionais na próxima subseção. 
faturado em sua moeda local. É segundo esta característica que exploraremos o foco deste estudo. Seja em uma operação com outro residente - em que a mesma moeda é utilizada por ambos os agentes-, seja em um operação entre um residente em um país e um residente em outro país, para o vendedor (exportador), a possibilidade de recebimento na mesma moeda implica uma receita de montante igual, sem a necessidade de recorrer a uma operação de câmbio privada, que implicaria a adição de custos de câmbio para o exportador.

Embora, neste trabalho, enfoquemos a análise das consequências diretas de disponibilização de um sistema tal qual o SML sobre a interação econômica entre os agentes, é conveniente também destacar alguns aspectos relacionados ao processamento que se dá internamente ao sistema de pagamentos, que compreende a interação entre os bancos centrais dos dois países.

Ilustramos na figura 11 o esquema interno de compensações do SML. Primeiramente, a liquidação das ordens de pagamento entre os bancos centrais é feita pelo valor líquido diário das operações. Todas as ordens de pagmento recebidas e registradas são acumuladas durante o dia pelo banco central do remetente $\left[1\right.$ e $\left.1^{\prime}\right]$. Ao final do dia, os bancos centrais convertem os valores pelos quais as ordens originalmente foram registradas para o valor na moeda do outro país como para a moeda de liquidação entre os bancos centrais, que é o USD. Com os valores nas três moedas, os bancos centrais dão seguimento ao envio das ordens de pagamento [2] e calculam o valor líquido do somatório das ordens de pagamento remetidas pelos dois países. Este valor líquido é pago pelo banco central devedor ao banco central credor, por uma transferência de reservas internacionais [3; no exemplo o Brasil é o país devedor]. As ordens de pagamento transferidas ao banco central correspondente ao destinatário são pagas às respectivas instituições financeiras já denominadas na moeda do país de destino $\left[4\right.$ e $\left.4^{\prime}\right]$.

Duas taxas de câmbio são então utilizadas. A primeira é a taxa de câmbio entre a moeda de registro da ordem de pagamento e a moeda de liquidação entre os bancos centrais. Neste caso, trata-se da taxa de câmbio entre a moeda nacional e o dólar americano. No caso brasileiro, é utilizada a taxa de câmbio entre o BRL e o USD, chamado de PTAX ${ }^{5}$, e, no caso argentino, é utilizada a taxa entre o ARS e o USD, chamada de Tipo de Referencia ${ }^{6}$. A segunda taxa utilizada é para conversão entre as duas moedas nacionais-BRL e ARSe é chamada Taxa SML. A Taxa SML é uma taxa cruzada entre as taxas apresentadas

5 A PTAX é divulgada pelo BCB. Trata-se da média das taxas de compra e de venda da PTAX de fechamento (Banco Central do Brasil, 2014). As PTAXs de compra e venda de fechamento são, respectivamente, as médias aritméticas das taxas das cotações de compra e das cotações de venda fornecidas pelas instituições financeiras operadoras de câmbio selecionadas-dealers - ao BCB (Banco Central do Brasil, 2010).

6 O Tipo de Referencia é calculado pelo BCRA a partir do mercado de câmbio argentino 
Figura 11 - Esquema interno do SML

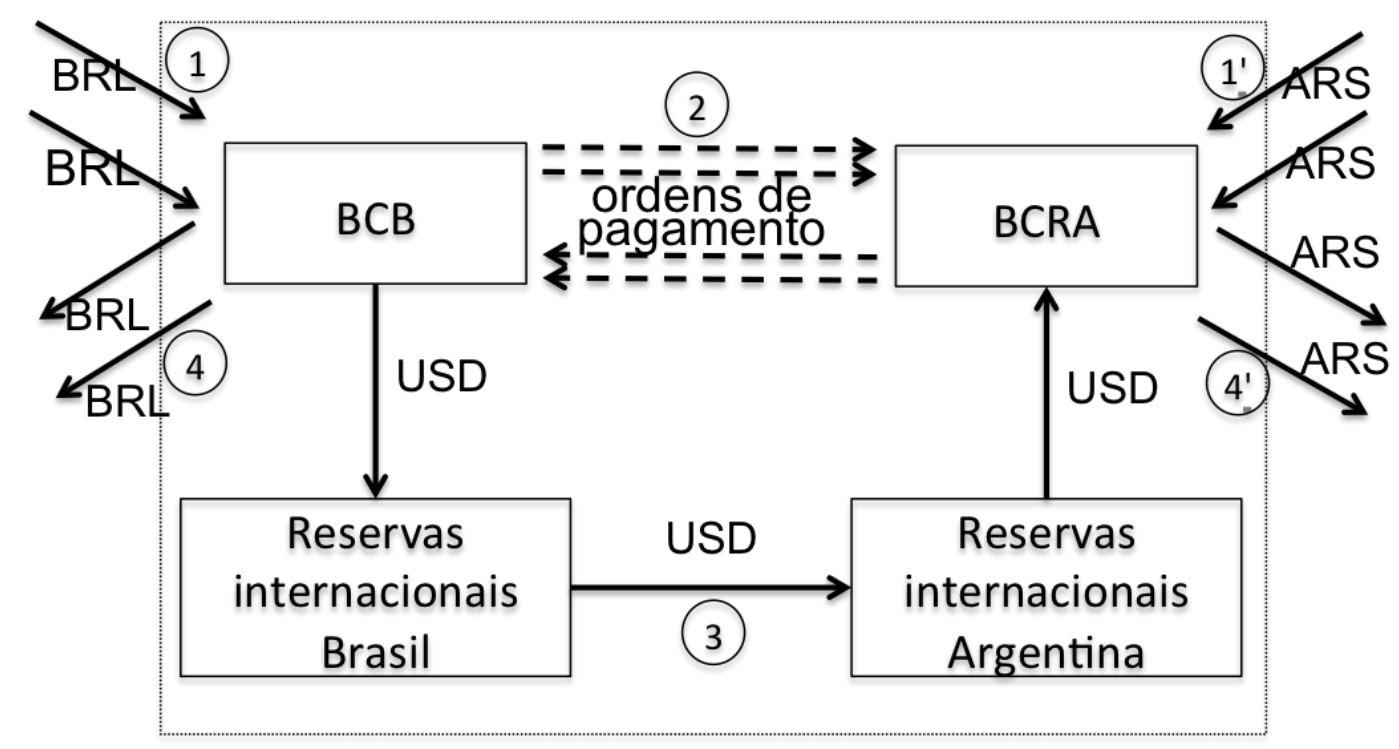

anteriormente em relação ao USD e expressa como uma relação entre ARS/BRL e como $\mathrm{BRL} / \mathrm{ARS}$.

Uma característica desta taxa calculada é o fato de ela ser a mesma utilizada pelos bancos centrais em sua contabilidade interna (Banco Central do Brasil, 2014), o que, trivialmente evita a existência contábil de variações cambiais para os bancos centrais uma vez que a taxa de conversão de moeda ofertada pelo banco central para os agentes é a mesma pela qual ele registra diariamente as operações em moeda estrangeira. A avaliação dos eventuais riscos cambiais presentes no sistema para os bancos centrais, assim como a avaliação dos impactos causados pela expansão e contração da base monetária ocorrida em razão do direto crédito e débito dos valores nas contas de reserva bancária das instituições financeiras são questões relevantes, mas fogem ao escopo do presente estudo, sendo deixadas para reflexões futuras.

O último aspecto interno que destacaremos é a frequência de liquidação entre os bancos centrais, que é diária. É esta questão operacional que exige a margem de contingência aprovada segundo a legislação destaca na subseção 4.2.1. Como a liquidação entre os bancos centrais ocorre por meio de uma operação em um centro financeiro diferente dos dois países, onde são mantidas suas reservas internacionais, a frequência de liquidação diária das operações exige a previsão do caso em que este centro financeiro não está disponível, por exemplo, quando é feriado bancário no centro financeiro mas não o é nos países convenentes. A solução operacional adotada é a concessão de um crédito financeiro para que a compensação seja feita em um próximo dia. Este crédito financeiro é a margem de contingência. 


\subsection{Volatilidade da moeda e incerteza de preços}

As interações econômicas se beneficiam da existência da moeda. A existência de um meio de troca resolve o problema da dupla coincidência de desejos que ocorreria em um sistema puramente baseado em escambo (JEVONS, 1875). A fim de se mensurar o valor dos bens comercializados, a escolha de uma moeda para faturar operações de comércio fornece uma unidade de medida, o que é tratado na literatura como a função da moeda de unidade de conta.

Uma firma maximiza seu lucro lidando com suas funções de receita e custo. Quando esta firma interage economicamente com uma firma em outro país, ambas escolhem a quantidade e o preço dos bens que comercializam de forma a maximizar suas próprias funções de lucro. Ao se deparar com o uso de diferentes moedas para denominar receitas e despesas, o gerenciamento destes dois montantes está sujeito à taxa de câmbio que relaciona o valor relativo entre as moedas envolvidas. Como o momento de faturamento da operação é diferente do momento de pagamento da operação comercial, nós podemos assumir que a taxa de câmbio entre as moedas também irá variar entre os dois momentos em um sistema de câmbio que não seja fixo. Assim, a decisão de precificação do produto no momento do faturamento é tomada sob a expectativa do valor da taxa de câmbio na data de pagamento da operação e, então, a volatilidade cambial se transforma em incerteza acerca da quantia que será recebida com relação ao preço originalmente faturado.

Logo, escrevemos o preço usado para negociar o contrato de faturamento como uma expectativa tida a partir do preço no mercado internacional do produto e da expectativa da taxa de câmbio na data do pagamento:

$$
\mathrm{E}_{t}\left[p_{c_{h}}\right]=\mathrm{E}_{t}\left[e_{t+s}\right] \cdot p_{c_{f}}
$$

em que $\mathrm{E}_{t}(\cdot)$ é a esperança no período $t, e_{t}$ é a taxa de câmbio no período $t, p_{c_{h}}$ é o preço em moeda local e $p_{c_{f}}$ é o preço faturado em moeda estrangeira.

Uma possível solução para se reduzir a volatilidade da receita esperada é recorrer ao mercado futuro. Existindo um mercado futuro suficientemente desenvolvido, o nível de produção não é afetado pela incerteza e depende apenas do valor da taxa a termo (ETHIER, 1973). A literatura que associa este mercado como meio de mitigação de incertezas é extensa e inclui Benninga, Eldor e Zilcha (1985), Kawai e Zilcha (1986), Ware e Winter (1988), Adam-Müller (1997), Brown (2001), Chang e Wong (2003). Adicionalmente ao mercado futuro, a utilização de moedas com a finalidade de proporcionar um casamento entre a denominação de receitas e de despesas também pode ser considerada uma forma 
de se atingir uma situação de eficiência produtiva, quando os agentes podem escolher livremente a moeda que utilizam e não sofrem a indução de uma moeda especifica pelo governo.

Entretanto, seguindo a argumentação já desenvolvida no ensaio 3, a escolha da moeda utilizada pelos agentes não é irrestrita. Desta forma, a conclusão de a situação de mitigação de riscos de câmbio ser uma solução eficiente está condicionada à política prévia de adoção ou não destas restrições, o que chamamos de política de indução da moeda nacional. Com efeito, esta decisão ex-ante é comumente tomada como situação padrão de uma economia. Ao ser modelado o comportamento de lucros de uma firma, geralmente observamos a hipótese de seus lucros serem denominados na moeda nacional ${ }^{7}$. Em outras palavras, podemos descrever esta hipótese pela situação correspondente à completa indução de uma moeda pelo governo de um país. Em economias onde há o banimento de moedas estrangeiras e cuja moeda nacional possui baixo grau de internacionalidade, a relação entre as duas hipóteses se mostra precisa. Este é exatamente o caso para o qual trazemos atenção neste ensaio ao considerar Argentina e Brasil, em que as moedas não possuem suficiente internacionalidade e o uso de uma moeda veículo é comum, conforme mostramos para o caso brasileiro no ensaio 2.

As consequências da volatilidade cambial sobre as firmas sob ausência de mercado futuro já foi analisada na literatura econômica. Viaene e Vries (1992) associou o aumento da volatilidade cambial à redução de exportações e de importações, enquanto que Viaene e Zilcha (1998) destacam que as consequências das incertezas são dependentes da forma funcional da produção das firmas. Efeitos sobre o resultado das firmas são observados mesmo com a existência de mercados futuros. Estes resultados ocorrem quando a proteção cambial não é feita por mecanismos diretamente associados à operação principal (BROLL; WAHL; ZILCHA, 1995) e ainda, mesmo que se consiga eliminar os impactos sobre a produção, ocorrerá redistribuição das quantidades comercializadas segundo a origem dos compradores (BROLL; WONG; ZILCHA, 1999).

Nós passamos a confirmar estas análises, segundo o ambiente de análise que desenvolvemos de baixa internacionalidade da moeda e banimento de moedas estrangeiras. Seguindo Sandmo (1971), nós sabemos que, para uma firma produzindo sob incerteza de preços, o volume de sua produção é menor do que o volume de sua produção sob certeza de preços. Este resultado decorre da hipótese central de que a decisão relacionada com quanto deverá ser produzido é tomada em momento anterior ao momento em que ocorrem as vendas, quando o preço de mercado se torna conhecido. Nossa tese é que a volatilidade da taxa de câmbio produz o mesmo efeito de incerteza sobre o preço de venda. Como uma moeda estrangeira é utilizada para faturamento, o preço em moeda local - ou na moeda

7 Para um exemplo recente de utilização desta hipótese, vide Wong (2013). 
utilizada referência na estrutura de custo do produtor - oscila. Portanto, a decisão de maximização do produtor é tomada sob incerteza, do ponto de vista da denominação em moeda local, o que expressamos em (4.1). Tomemos uma empresa que usa sua moeda local como referência para avaliar seus negócios e definir seus preços. O uso de outra moeda para denominar suas receitas produz incerteza sobre o valor das receitas em moeda local, que se assume intencionar corresponder os seus custos e é utilizado como referência para decisão de oferta do exportador. Assim, afirmamos:

Afirmação 10 Nas interações entre uma firma residente e firmas não residentes, as vendas sob o uso de uma moeda veículo são menores do que elas seriam caso a moeda local fosse utilizada para denominar estas exportações, quando a estrutura de custos do vendedor é completamente baseada na moeda local e não existe mercado de câmbio futuro.

Demonstração. Nós seguimos a demonstração de (SANDMO, 1971) para a redução de produção de uma firma sob incerteza de preço, aplicando a condição descrita na equação (4.1). Seja uma firma engajada em exportação, significando que ela interage economicamente com agentes estrangeiros que não aceitam a moeda da exportadora para faturar. A firma objetiva maximizar a utilidade esperada dos lucros e é avessa ao risco. As hipóteses usuais para as funções de utilidade se aplicam, sendo limitada, côncava, contínua e duas vezes diferenciável em relação ao lucro de forma que

$$
U^{\prime}(\pi)>0, U^{\prime \prime}(\pi)<0
$$

Nós assumimos que a política de indução da moeda nacional por meio do banimento de moedas estrangeiras é suficientemente elevada, fazendo com que a firma não tenha condições de considerar em sua função de custos uma referência que seja em moeda estrangeira $^{8}$. A função de custo da firma, denominada na moeda local $c_{h}$, pode então ser descrita por

$$
F_{i}^{c_{h}}(x)=C_{i}^{c_{h}}(x)+B_{i}^{c_{h}}
$$

em que $x$ é a produção, $C_{i}^{c_{h}}(x)$ é a função dos custos variáveis da firma (com $\left.C_{i}^{c_{h}}(0)=0, C_{i}^{c_{h}{ }^{\prime}}(x)>0\right)$ e $B_{i}^{c_{h}}$ é o custo fixo. O lucro da firma denominado na moeda

8 Isto é consistente com o fato de a moeda de referência ser induzida por uma política do governo. Poderíamos alegar que existem firmas que têm substancial fração de seus insumos importados. Consequentemente, sua referência tenderia a ser tida em moeda estrangeira, o que implica que a obrigação legal de a firma ter uma de referência em moeda nacional um custo adicional. Neste caso, a diferenciação existente entre as consequências de uma política de indução da moeda sobre estes dois tipos de firma acentuaria as distorções que buscamos destacar. Logo, a adoção da função de custos em moeda nacional é, para nosso objetivo, uma aproximação pelo menos tão boa quanto uma representação por um conjunto de funções em diversas moedas. 
local, com os custos totalmente denominados também na moeda local, pode ser descrito pelas equações

$$
\begin{gathered}
\pi_{i}^{c_{h}}(x)=p^{c_{h}} x-C_{i}^{c_{h}}(x)-B_{i}^{c_{h}} \\
\pi_{i}^{c_{h}}(x)=p^{c_{h}} x-C_{i}^{c_{h}}(x)-B_{i}^{c_{h}}=\mathrm{E}\left[p^{c_{h}}\right] x-C_{i}^{c_{h}}(x)-B_{i}^{c_{h}}
\end{gathered}
$$

, em que (4.4a) descreve uma venda para um agente residente no mercado interno e, portanto, faturada também na moeda de referência, enquanto (4.4b) descreve uma venda para um agente não-residente para o qual há de se vender em uma outra moeda. Assim, $p^{c_{h}}$ é o preço do produto denominado na moeda local a partir da conversão do preço fixado $p^{c_{f}}, \operatorname{com} \pi^{c_{h}}(0)=-B^{c_{h}}$. Como argumentamos na equação (4.1), $\mathrm{E}_{t}\left[p^{c_{h}}\right]=\mathrm{E}_{t}\left[e_{t+s}\right] \cdot p^{c_{f}}$; $p^{c} \geq 0, e \geq 0$. Nós assumimos $e$ como uma variável aleatória, o que faz $p^{c_{h}}$ ter função de densidade $f\left(p^{c_{h}}\right)$ e valor esperado $E\left[p^{c_{h}}\right]=\mu^{c_{h}}$.

Dado um valor de produção $x$, a máxima perda da firma é dada por $-C_{i}^{c h}(x)-$ $B_{i}^{c_{h}}$. Tomando as equações $(4.2)$ e $(4.4 \mathrm{~b})$, nós podemos escrever a esperança da função utilidade como $\mathrm{E}\left[U\left(p^{c_{h}} x-C_{i}^{c_{h}}(x)-B_{i}^{c_{h}}\right)\right]$. As condições para uma solução de máximo, que assumimos existir e ser única, são:

$$
\begin{gathered}
\mathrm{E}\left[U^{\prime}\left(\pi_{i}^{c_{h}}\right)\left(p^{c_{h}}-C_{i}^{c_{h} \prime}(x)\right)\right]=0 \\
\mathrm{E}\left[U^{\prime \prime}\left(\pi_{i}^{c_{h}}\right)\left(p^{c_{h}}-C_{i}^{c_{h}}(x)\right)^{2}-U^{\prime}\left(\pi_{i}^{c_{h}}\right) C_{i}^{c_{h} \prime \prime}(x)\right]<0
\end{gathered}
$$

Em vendas realizadas na moeda local e, portanto, sob certeza de preços segundo a equação (4.4a), a solução é dada pela igualdade entre os preços denominados na moeda local $^{9}$ e os custos marginais também denominados nesta moeda, $p^{c_{h}}=C_{i}^{c_{h}}(x)$.

Para mostrar a produção sob a incerteza decorrente da volatilidade cambial, nós reescrevemos (4.5) como $E\left[U^{\prime}\left(\pi_{i}^{c_{h}}\right) p^{c_{h}}\right]=E\left[U^{\prime}\left(\pi_{i}^{c_{h}}\right) C_{i}^{\prime}(x)\right]$ e subtraímos $E\left[U_{i}^{\prime}\left(\pi_{i}^{c_{h}}\right) \mu^{c_{h}}\right]$ nos dois lados da equação, obtendo:

$$
E\left[U^{\prime}\left(\pi_{i}^{c_{h}}\right)\left(p^{c_{h}}-\mu^{c_{h}}\right)\right]=E\left[U^{\prime}\left(\pi_{i}^{c_{h}}\right)\left(C_{i}^{c_{h^{\prime}}}(x)-\mu^{c_{h}}\right)\right]
$$

De (4.4a), $E\left[\pi_{i}^{c_{h}}\right]=\mu^{c_{h}} x-C_{i}^{c_{h}}(x)-B_{i}^{c_{h}}$. Então, $\pi_{i}^{c_{h}}=E\left[\pi_{i}^{c_{h}}\right]+\left(p^{c_{h}}-\mu^{c_{h}}\right) x$. Logo,

$$
p^{c_{h}} \geq \mu^{c_{h}} \rightarrow U^{\prime}\left(\pi_{i}^{c_{h}}\right) \leq U^{\prime}\left(E\left[\pi_{i}^{c_{h}}\right]\right)
$$

$9 \quad$ Novamente, nós destacamos que assumimos que as firmas locais utilizam a moeda local como referência para suas operações, algo que justificamos na seção 3.3 . 


$$
p^{c_{h}} \leq \mu^{c_{h}} \rightarrow U^{\prime}\left(\pi_{i}^{c_{h}}\right) \geq U^{\prime}\left(E\left[\pi_{i}^{c_{h}}\right]\right)
$$

Multiplicando-se (4.8a) e (4.8b) por $\left(p_{c_{h}}-\mu_{b}\right)$, garantimos o sinal da desigualdade, obtendo:

$$
U^{\prime}\left(\pi_{i}^{c_{h}}\right)\left(p^{c_{h}}-\mu^{c_{h}}\right) \leq U^{\prime}\left(E\left[\pi_{i}^{c_{h}}\right]\right) E\left[p^{c_{h}}-\mu^{c_{h}}\right], \forall p^{c_{h}}
$$

Tomando a esperança em (4.9) e observando que $U^{\prime}\left(E\left[\pi_{i}^{c_{h}}\right]\right)$ é um determinado número, nós obtemos:

$$
E\left[U^{\prime}\left(\pi_{i}^{c_{h}}\right)\left(p^{c_{h}}-\mu^{c_{h}}\right)\right] \leq U^{\prime}\left(E\left[\pi_{i}^{c_{h}}\right]\right) E\left[p^{c_{h}}-\mu^{c_{h}}\right]
$$

Por definição, $U^{\prime}\left(E\left[\pi_{i}^{c_{h}}\right]\right) E\left[p^{c_{h}}-\mu^{c_{h}}\right]=0$. Logo, da equação (4.7),

$$
E\left[U^{\prime}\left(\pi_{i}^{c_{h}}\right)\right]\left(C_{i}^{\prime}(x)-\mu^{c_{h}}\right)=E\left[U^{\prime}\left(\pi_{i}^{c_{h}}\right)\left(p^{c_{h}}-\mu^{c_{h}}\right)\right] \leq 0
$$

Como a utilidade marginal é sempre positiva,

$$
C_{i}^{\prime}(x) \leq \mu^{c_{h}}=E_{t}\left[e_{t+s}\right] p^{c_{f}}
$$

Nós também podemos mostrar que, sob as condições da afirmação 10,

Afirmação 11 O total produzido está inversamente relacionado à volatilidade da taxa de câmbio.

\section{Demonstração.}

Ainda aplicamos a equação (4.1) à demonstração geral provida por Sandmo (1971). Definamos os parâmetros de deslocamento multiplicativo $\gamma$ e aditivo $\theta$ em relação à distribuição de probabilidade ao valor médio da taxa de câmbio e temos:

$$
\gamma p^{c_{h}}+\theta
$$

Para manter a média constante, tendo como referência os valores $(\gamma, \theta)=(1,0)$, nós devemos manter a relação entre ambos os parâmetros de forma que $d E\left[\gamma p^{c_{h}}+\theta\right]=$ $0 \Rightarrow \mu^{c_{h}} d \gamma+d \theta=0$, ou

$$
\frac{d \theta}{d \gamma}=-\mu^{c_{h}}
$$


Reescrevendo a função de lucros (4.4a) como $\pi_{i}^{c_{h}}(x)=\left(\gamma p^{c_{h}}+\theta\right) x-C_{i}^{c_{h}}(x)-B_{i}^{c_{h}} \mathrm{e}$ diferenciando em relação à $\gamma$, tendo (4.14):

$$
\frac{d x}{d \gamma}=-x \frac{1}{D} E\left[U_{i}^{b \prime \prime}\left(\pi_{i}^{c_{h}}\right)\left(p^{c_{h}}-\mu^{c_{h}}\right)\left(p^{c_{h}}-C_{i}^{c_{h} \prime}(x)\right)\right]-\frac{1}{D} E\left[U^{\prime}\left(\pi_{i}^{c_{h}}\right)\left(p^{c_{h}}-\mu^{c_{h}}\right)\right]
$$

em que $D=E\left[U^{\prime \prime}\left(\pi_{i}^{c_{h}}\right)\left(p^{c_{h}}-C_{i}^{c_{h}{ }^{\prime}}(x)\right)^{2}-U^{\prime}\left(\pi_{i}^{c_{h}}\right) C_{i}^{c_{h} \prime \prime}(x)\right]$. Da condição de segunda ordem expressa pela inequação (4.6), $D<0$ e, da equação (4.11), $E\left[U^{\prime}\left(\pi_{i}^{c_{h}}\right)\left(p^{c_{h}}-\mu^{c_{h}}\right)\right] \leq$ 0. A segunda parcela é negativa. Tomamos a avaliação local, observando que quando o preço é conhecido e igual a $\mu^{c_{h}}$, nós temos de ter $C_{i}^{c_{h}{ }^{\prime}}=\mu^{c_{h}}$ e, então a primeira parcela se torna $-x \cdot \frac{1}{D} \cdot E\left[U_{i}^{b \prime \prime}\left(\pi_{i}^{c_{h}}\right)\left(p^{c_{h}}-\mu^{c_{h}}\right)^{2}\right]$, que é negativo.

$$
\therefore \frac{d x}{d \gamma}<0
$$

Assim, nesta seção, nós identificamos que a necessidade de denominação em uma moeda diferente daquela que a firma utiliza como referência altera o resultado da produção, associando este resultado a um país que impede a utilização de moedas estrangeiras pelos seus residentes e que, ao comercializarem com agentes estrangeiros, se vêem obrigados a utilizarem uma moeda diferente daquela que lhes é induzida, como consequência de sua baixa internacionalidade.

\subsection{A predileção pela intervenção do SML}

Nesta seção, vamos discutir a predileção pela implantação pelo governo de uma política conforme a disponibilização do SML, ou seja, de provimento pelo governo de instrumentos de pagamentos entre comerciantes em países distintos, tendo-o associado a uma operação cambial, sob o ambiente doméstico de banimento de moedas estrangeiras e cujas moedas nacionais apresentem baixa internacionalidade. Nós seguimos o apresentado por (BHAGWATI, 1971), segundo sabemos que um intervenção feita por uma política de governo conduz a um resultado preferível (ótimo) quando ela é direcionada diretamente para compensar a alteração econômica decorrente de uma política anteriormente introduzida. Nossa hipótese de indução da moeda, quando um governo adota em grau elevado uma política de restringir seus agentes residentes a utilizarem a moeda que ele emite, foi observada como causa de alterações econômicas. 
No caso específico em análise dos mercados entre Argentina e Brasil, observamos que ambos os países induzem seus residentes a utilizarem suas moedas nacionais, o peso argentino e o real respectivamente. Observamos também que ambas as moedas possuem baixa internacionalidade e ainda que este efeito é ampliado quando se considera uma interação direta entre elas. O mercado cambial entre as duas moedas é incipiente, assim como são os instrumento financeiros de proteção cambial entre elas ${ }^{10}$. Para comercializarem entre si, os residentes em cada um dos países recorrem a moedas internacionais, em especial, ao dólar americano ${ }^{11}$.

Uma forma de se tornar mais direta a observação dos efeitos das incertezas sobre a produção da firma é tratar a incerteza cambial como um problema de custo adicionado, similarmente ao realizado no ensaio $3^{12}$. Bollerslev e Melvin (1994) mostram que o bidask spread, que é associado ao custo de transação em uma moeda, está positivamente correlacionado com a incerteza decorrente da volatilidade da taxa de câmbio. Assim, podemos associar o problema da realocação de renda decorrente das incertezas sobre o valor da moeda ao custo de câmbio de cada uma.

Notamos que a escolha pelo comércio denominado em uma moeda internacional equivale a escolha do agente residente em adotar uma incerteza de preços segundo descrita conforme a equação (4.4b), em detrimento da equação (4.4a) de produção sobre certeza de preços. Este caso de certeza de preços somente ocorre quando todos os preços forem denominados na moeda nacional, como consequência da obrigatoriedade do uso da moeda nacional em decorrência da política de indução da moeda. A indisponibilidade de instrumentos financeiros entre as moedas não-internacionais torna a operação de venda para o exterior na moeda localmente induzida onerosa - ou mesmo impossível-implicando a escolha do agente recair sobre a situação de incerteza.

Observe que a disponibilização do SML pelo governo permite que o agente possa comercializar com o exterior na moeda localmente induzida - reais ou pesos, mesmo que a baixa internacionalidade apresentada por elas não tenha permitido um mercado financeiro suficientemente desenvolvido para que elas pudessem se tornar referência das operações. Ao ter um instrumento financeiro na moeda de baixa internacionalidade, a comercialização com agentes residentes ou não-residentes passa a ser equivalente em termos da moeda de denominação da operação, eliminando o efeito da política de indução de uma moeda de

10 A incipiência do mercado entre as moedas dos dois países é ainda mais perceptível quando se nota que somente após a introdução do SML houve a divulgação de uma taxa de câmbio entre o real e o peso argentino pelos provedores de informação. Ainda assim, a taxa entre as duas moedas é apresentada como referência, pelo cruzamentos das taxas de câmbio de cada uma em relação ao dólar americano. Para dados empíricos, vide ensaio 2 (REISS, 2015).

12 No ensaio 3, também observamos o problema de realocação de renda sobre a ótica de custos. Lá, entretanto, o custo é considerado como consequência da indisponibilidade de instrumentos financeiros em uma determinada moeda 
baixa internacionalidade. Temos, então que

Conclusão 12 Uma vez dada a política de indução das moedas nacionais, o SML é um método menos custoso de se introduzir uma distorção na economia de forma a lidar com a restrição de liquidez em moeda local.

\subsection{Comentários finais}

Neste ensaio, nós analisamos a política governamental de oferecer o SML segundo seu perfil financeiro - uma visão que é explorada pela primeira vez na literatura. Destacamos o caráter inovador do sistema, que associa a disponibilidade de instrumentos financeiros ao comportamento de escolha de moeda pelos agentes, algo que foi verificado empiricamente no ensaio 2. Aqui, em uma análise parcial, focamos os efeitos da falta de disponibilidade de instrumentos financeiros para comercializar com o exterior, o que é próprio de uma moeda com baixa internacionalidade.

Sob a perspectiva de uma política com objetivos distintos da otimização da renda ou da produção - a política de o país ter moeda nacional - perguntamos qual o efeito da oferta pública de um instrumento financeiro, o SML. Concluímos que, sob a política de obrigatoriedade de uso de uma moeda de baixa internacionalidade, a introdução do SML lida diretamente com os efeitos desta política, conduzindo-nos à identificação de ser uma política menos custosa que outras possíveis intervenções para lidar com as consequências distorcivas da política original relacionadas tanto ao real quanto ao peso argentino.

Permanece como proposta de avaliação posterior a contabilização dos custos da política e a sua consideração à luz de uma mensuração das distorções causadas pela política de obrigatoriedade de uma moeda nacional. Neste arcabouço, a proposta de mensuração de benefícios e custos de política de moeda nacional, tal como sugerida no ensaio 3, é reforçada. Parece claro que, em economias com fortes políticas de indução da moeda, a compreensão e a mensuração dos efeitos redistributivos merecem maior investigação. 


\section{Considerações finais}

Os ensaios apresentados buscaram contribuir para uma resposta à discussão normativa sobre a internacionalização da moeda brasileira. Constatamos que não se trata nem de uma resposta trivial, nem de uma que esteja consolidada na literatura.

Iniciamos discutindo a imprecisão do termo moeda internacional no primeiro ensaio e propusemos o conceito de internacionalidade da moeda como a propriedade multidimensional de uma moeda ter suas funções da moeda reconhecidas além do domínio que está sujeito à regulação de sua autoridade emissora e o utilizamos para consolidar a compreensão de moeda internacional.

Partimos deste conceito para testar a existência de internacionalidade para o BRL, o que foi feito no segundo ensaio. Nele, verificamos duas dimensões da internacionalidade do BRL e confirmamos sua existência. Ao analisarmos os dados do faturamento do comércio exterior brasileiro, confirmamos a utilização do BRL como moeda de faturamento e garantimos a ocorrência do uso do BRL como unidade de conta por agentes não-residentes no Brasil. Ao analisarmos os dados de transferências financeiras em BRL, confirmamos a sua utilização como meio de troca por agentes não-residentes.

A observação da existência de internacionalidade permitiu consolidar um caminho de novas questões para avaliações futuras sobre o BRL no cenário internacional. Além das propostas deixadas, com os dados brasileiros que trabalhamos, pudemos trazer novas contribuições para os mais atuais debates sobre a escolha de moedas de faturamento. Estabelecemos uma primeira ligação entre uma política de disponibilização de instrumentos financeiros e a escolha da moeda de faturamento pelos agentes. Notamos também no Brasil a prevalência do faturamento em BRL de produtos homogêneos, algo que não seria esperado a partir das hipótese tradicionais do comércio internacional para a escolha de moedas, contribuindo assim para reforçar a ideia de poder de barganha entre compradores e vendedores nesta questão. Ainda, observamos que, no caso brasileiro, a escolha da moeda para faturamento e para pagamento não coincidem, algo que vem sido recorrentemente registrado para outros países.

Passamos então ao estudo das ponderações para a adoção de uma política de governo. No ensaio três, propusemos uma nova questão a ser considerada: a distribuição de renda. Notamos que o Brasil, assim como diversos países, adota uma política de induzir fortemente o uso do BRL pelos residentes banindo o uso de moedas estrangeiras em seu território. Mostramos que esta opção de política redistribui renda ao compelir os residentes 
a utilizarem a moeda nacional quando interagindo com outros residentes e uma outra moeda quando interagindo com não-residentes que não reconheçam a internacionalidade da moeda nacional. Neste sentido, a internacionalização do BRL poderia reduzir as distorções causadas para os residentes no Brasil, que são impedidos de utilizar moedas estrangeiras em interações econômicas locais.

Finalizamos com o quarto ensaio analisando uma política brasileira como uma política atuante sobre a internacionalidade da moeda. Refletimos sobre a experiência argentino-brasileira de introdução do Sistema da Pagamentos em Moeda Local (SML) como uma inovadora política financeira, afastando-nos das prévias análises que haviam focado em seus aspecto comercial. Esta alteração de ponto de vista analítico, permitiu-nos tratar o sistema como uma política de governo que atua sobre a distorção apresentada no terceiro ensaio - a redistribuição de renda. O resultado desta percepção ainda se torna mais forte quando analisamos que esta atuação ocorre diretamente sobre o foco da distorção econômica, levando-nos à conclusão de o SML ser uma maneira menos custosa de lidar com a redistribuição de renda causada pela política de indução da moeda nacional associada à ausência de instrumentos financeiros disponíveis nas moedas induzidas.

Destacamos diversas propostas de estudos futuros em cada um dos quatro ensaios, representando sugestões de expansão em cada uma das suas frentes de pesquisa. Desta forma, pavimentamos e estimulamos o desenvolvimento do conhecimento sobre as moedas no cenário internacional e, em específico, sobre o papel da moeda emitida pelo Brasil neste cenário. 


\section{Referências Bibliográficas}

ADAM-MÜLLER, A. F. A. Export and hedging decisions under revenue and exchange rate risk: A note. European Economic Review, v. 41, n. 7, p. 1421-1426, jul. 1997. ISSN 0014-2921. Disponível em: <http://www.sciencedirect.com/science/article/pii/S0014292196000293>. Citado na página 110.

ANDREWS, D. M. International Monetary Power. Ithaca, N.Y: Cornell University Press, 2006. ISBN 978-08-01444-56-2. Citado na página 40.

ANDREWS, D. M. Power, Statecraft, and International Monetary Relations. In: International Monetary Power. New York: Cornell University Press, 2006. p. 7-28. Citado na página 17.

APPLEYARD, D.; FIELD, A. International Economics. 8 edition. ed. New York: McGraw-Hill/Irwin, 2013. ISBN 9780078021671. Citado na página 33.

ARIDA, P. Ainda sobre a conversibilidade. Revista de Economia Política, v. 23, n. 3, p. 135-142, 2003. Citado 2 vezes nas páginas 18 e 19.

ARIDA, P. Por uma moeda plenamente conversível. Revista de Economia Política, v. 23, n. 3, p. 151-154, 2003. ISSN 0101-3157. Citado 2 vezes nas páginas 18 e 19.

ARIDA, P.; BACHA, E. L.; LARA-RESENDE, A. Credit, Interest, and Jurisdictional Uncertainty: Conjectures on the Case of Brazil. In: GIAVAZZI, F.; GOLDFAJN, I.; HERRERA, S. (Ed.). Inflation Targeting, Debt, and the Brazilian Experience, 1999 to 2003. Cambridge: MIT Press, 2005. p. 265-294. ISBN 9780262072595. Citado na página 19.

Associated Press. Plane diverted as passengers fight over seat reclining. The Guardian, ago. 2014. ISSN 0261-3077. Disponível em: < http://www.theguardian.com/business/2014/ aug/26/plane-diverted-as-passengers-fight-over-seat-reclining $>$. Citado na página 76 .

BACCHETTA, P.; WINCOOP, E. van. A theory of the currency denomination of international trade. Journal of International Economics, v. 67, n. 2, p. 295-319, dez. 2005. ISSN 0022-1996. Citado na página 40.

BACHA, E. L. Reflexões pós-cepalinas sobre inflação e crise externa. Revista de Economia Política, v. 23, n. 3, p. 143-150, jul. 2003. Disponível em: < http: //www.rep.org.br/pdf/91-8.pdf>. Citado na página 18.

Banco Central de la República Argentina. ¿Qué es el SML? 2014. Disponível em: $<$ http://www.bcra.gov.ar/pdf/smlque\%20es\%20el\%20sml.pdf>. Citado na página 102.

Banco Central de la República Argentina; Banco Central del Uruguay. Carta de Intención entre Banco Central de Argentina y Banco Central del Uruguay para facilitar Sistema de Pagos en Moneda Local entre ambos países. 2012. Disponível em: <http://www.bcu.gub.uy/>. Citado na página 103. 
Banco Central de la República Argentina; People's Bank of China. Acuerdo de Swap de monedas entre el BCRA y el Banco Central de China. 2014. Disponível em: <http://www.bcra.gov.ar/pdfs/comytexord/P50421.pdf>. Citado na página 102.

Banco Central do Brasil. O dinheiro brasileiro: o real - 1994 a 2006. Brasília: BCB, 2007. ISBN 978-85-99863-08-4. Citado na página 41.

Banco Central do Brasil. Circular N. 3.506. 2010. Citado na página 108.

Banco Central do Brasil. Bancos Centrais do Brasil e da China estabelecem acordo de swap de moeda. 2013. Disponível em: < http://www.bcb.gov.br/pt-br/Paginas/ bancos_centrais_do_brasil_e_da_china_estabelecem_acordo_de_swap_de_moeda_ 26-03-2013.aspx>. Citado na página 102.

Banco Central do Brasil. Manual de Serviços de Administração Financeira. 2014. Citado 2 vezes nas páginas 108 e 109.

Banco Central do Brasil; Banco Central del Uruguay. Carta de inteções entre Banco Central do Brasil e Banco Central del Uruguay. 2012. 12/02/2012. Disponível em: $<$ http://www.bcb.gov.br/rex/sml/Carta-de-Intencoes-BCB-BCU.pdf $>$. Citado na página 103.

Bank for International Settlements. Estimating and interpreting probability density functions. Basel, 1999. Disponível em: <http://www.bis.org/publ/bisp06.pdf >. Citado na página 84.

Bank for International Settlements. Triennial Central Bank Survey: Global foreign exchange market turnover in 2013. Basel, 2014. Disponível em: < https: //www.bis.org/publ/rpfx13.htm>. Citado 2 vezes nas páginas 81 e 82.

BASNET, H. C.; SHARMA, S. C. Economic Integration in Latin America. Journal of Economic Integration, v. 28, n. 4, p. 551-579, dez. 2013. ISSN 1225-651X, 1976-5525.

Disponível em: <http://www.e-jei.org/journal/view.php?number=2013600028>. Citado na página 18.

BAUMANN, R.; MUSSI, C. Cooperação monetária e financeira: o que é bom para a ásia também é bom para a América Latina? Revista de Economia Política, v. 31, p. 77-97, 2011. 1. Citado na página 101.

BELAISCH, A. Exchange rate pass-trough in Brazil. Washington, 2003. Disponível em: <https://www.imf.org/external/pubs/ft/wp/2003/wp03141.pdf>. Citado na página 40.

BELLUZZO, L. G.; CARNEIRO, R. O mito da conversibilidade. Revista de Economia Política, v. 24, n. 2, p. 218-222, 2004. Citado na página 19.

BENNINGA, S.; ELDOR, R.; ZILCHA, I. Optimal international hedging in commodity and currency forward markets. Journal of International Money and Finance, v. 4, n. 4, p. 537-552, dez. 1985. ISSN 0261-5606. Disponível em: $<$ http://www.sciencedirect.com/science/article/pii/0261560685900282>. Citado na página 110.

BETTS, C.; DEVEREUX, M. B. The exchange rate in a model of pricing-to-market. European Economic Review, v. 40, n. 3-5, p. 1007-1021, 1996. ISSN 0014-2921. Citado na página 40. 
BHAGWATI, J. N. The generalized theory of distortions and welfare. In: Trade, balance of payments and growth; papers in international economics in honor of Charles $P$. Kindleberger. Amsterdam: North-Holland Pub. Co., 1971. p. 69-90. ISBN 0444100946 978044410094807204305189780720430516 . Citado na página 115.

BHAGWATI, J. N.; SRINIVASAN, T. N. Optimal Intervention to Achieve Non-Economic Objectives. The Review of Economic Studies, v. 36, n. 1, p. 27-38, jan. 1969. ISSN 0034-6527. Disponível em: < http://www.jstor.org/stable/2296340>. Citado na página 74.

BIANCARELI, A. M. O Brasil e a integração na América do Sul: iniciativas para o financiamento externo de curto prazo. www.ipea.gov.br, mar. 2011. Disponível em: $<$ http://repositorio.ipea.gov.br/handle/11058/1424>. Citado na página 101.

BIS. General principles for international remittance services. [S.1.], 2007. Disponível em: $<$ http://www.bis.org/cpmi/publ/d76.pdf>. Citado na página 107.

BIS. Innovations in retail payments. Basel, 2012. Disponível em: < http://www.bis.org/ cpmi/publ/d102.htm>. Citado na página 101.

BO, L. China Finance The Prospect of Renminbi Pricing in Cross-Border Trade. 2013. Disponível em: <http://finance.sina.com.cn/money/bank/bank \_hydt/20131202/ 145817501140.shtml>. Citado na página 66.

BOLLERSLEV, T.; MELVIN, M. Bid-ask spreads and volatility in the foreign exchange market. Journal of International Economics, v. 36, n. 3-4, p. 355-372, maio 1994. ISSN 00221996. Disponível em: <http://linkinghub.elsevier.com/retrieve/pii/ 0022199694900086>. Citado na página 116.

BOS, J. W. B.; KOLARI, J. W.; LAMOEN, R. C. R. van. Competition and innovation: Evidence from financial services. Journal of Banking 6 Finance, v. 37, n. 5, p. 1590-1601, maio 2013. ISSN 0378-4266. Citado na página 101.

BRASIL. Lei n. 11.803. 2008. Disponível em: <http://www.planalto.gov.br/ccivil \_03/ \_Ato2007 \discretionary $\{-\}\{\{\{\{\} 2010 / 2008 /$ Lei/L11803.htm> . Citado na página 104.

BRESSER-PEREIRA, L. C.; HOLLAND, M. Common currency and economic integration in Mercosul. Journal of Post Keynesian Economics, v. 32, n. 2, p. 213-234, dez. 2009. ISSN 0160-3477. Disponível em: <http://mesharpe.metapress.com/openurl.asp?genre= article\&id=doi:10.2753/PKE0160-3477320206> . Citado na página 18.

BROLL, U.; WAHL, J. E.; ZILCHA, I. Indirect hedging of exchange rate risk. Journal of International Money and Finance, v. 14, n. 5, p. 667-678, out. 1995. ISSN 0261-5606. Disponível em: <http://www.sciencedirect.com/science/article/pii/026156069500019B >. Citado na página 111.

BROLL, U.; WONG, K. P.; ZILCHA, I. Multiple Currencies and Hedging. Economica, v. 66, n. 264, p. 421-432, nov. 1999. ISSN 0013-0427. Disponível em: <http://www.jstor.org/stable/2555169>. Citado na página 111.

BROWN, G. W. Managing foreign exchange risk with derivatives. Journal of Financial Economics, v. 60, n. 2-3, p. 401-448, maio 2001. ISSN 0304-405X. Disponível em: <http://www.sciencedirect.com/science/article/pii/S0304405X01000496>. Citado na página 110. 
CALlUZZO, P.; DONG, G. N. Has the financial system become safer after the crisis? The changing nature of financial institution risk. Journal of Banking 63 Finance, v. 53, p. 233-248, abr. 2015. ISSN 0378-4266. Citado na página 101.

CASELLA, A. Arbitration in International Trade. [S.l.], 1992. Disponível em: $<$ http://ideas.repec.org/p/nbr/nberwo/4136.html>. Citado na página 31.

CAVAllO, A.; NEIMAN, B.; RIGOBON, R. Currency Unions, Product Introductions, and the Real Exchange Rate. The Quarterly Journal of Economics, v. 129, n. 2, p. 529-595, maio 2014. ISSN 0033-5533, 1531-4650. Disponível em: <http: //qje.oxfordjournals.org/content/129/2/529>. Citado na página 87.

Central Bank of Brazil. SML. 2012. Disponível em: < http://www.bcb.gov.br/?SML>. Citado na página 102.

CFC. Os princípios da contabilidade. 1993. Citado na página 83.

CHAGAS, L.; BAUMANN, R. Integração Monetária no Mercosul: ganhos com menores custos de transação? Economia Aplicada, v. 11, n. 1, p. 95-111, 2007. ISSN 1413-8050. Citado na página 18.

CHAGAS, L. L. Moeda única no Mercosul: aspectos fiscais. In: . Brasília: ESAF, 2004. (Prêmio Tesouro Nacional), p. 82. Disponível em: <http://www.tesouro.fazenda.gov.br/ premio_TN/IXPremio/mercosul/1mercosulIXPTN/1premio_mercosul.pdf $>$. Citado na página 18.

CHAMBERLAIN, E. The Theory of Monopolistic Competition. Cambridge, MA: Harvard University Press, 1933. Citado na página 94.

CHANG, E. C.; WONG, K. P. Cross-Hedging with Currency Options and Futures. The Journal of Financial and Quantitative Analysis, v. 38, n. 3, p. 555-574, set. 2003. ISSN 00221090. Disponível em: < http://www.jstor.org/stable/4126731>. Citado na página 110.

CLS GROUP. CLS. 2012. Disponível em: < http://www.cls-group.com>. Citado na página 47.

COHEN, B. J. The Seigniorage Gain of an International Currency: An Empirical Test. The Quarterly Journal of Economics, v. 85, n. 3, p. 494-507, ago. 1971. ISSN 0033-5533. Citado na página 71.

COHEN, B. J. The Geography of Money. Ithaca, NY: Cornell University Press, 2000. ISBN 978-0-8014-8513-8. Citado na página 30.

COHEN, B. J. Life at the Top: International Currencies in the 21st Century. Latin American Journal of Economics-formerly Cuadernos de Economía, v. 37, p. 9-34, 2000. 110. Disponível em: <http://EconPapers.repec.org/RePEc:ioe:cuadec:v:37:y:2000:i:110:p: 9-34>. Citado na página 16.

COHEN, B. J. The Macrofoundations of Monetary Power. In: International Monetary Power. New York: Cornell University Press, 2006. p. 31-50. Citado na página 17. 
COHEN, B. J. The Benefits and Costs of an International Currency: Getting the Calculus Right. Open Economies Review, v. 23, n. 1, p. 13-31, fev. 2012. ISSN 0923-7992, 1573-708X. Disponível em: <http://link.springer.com/article/10.1007/s11079-011-9216-2>. Citado 4 vezes nas páginas 16, 37, 43 e 96.

Comissão Mista Parlamentar. Parecer proferido em plenário à medida provisória n. 435, de 2008. Brasília, 2008. Disponível em: <http://www.camara.gov.br/proposicoesWeb/ prop_mostrarintegra? codteor $=595766 \&$ filename $=\mathrm{PPP}+1+\mathrm{MPV} 43508+\% 3 \mathrm{D} \% 3 \mathrm{E}+$ MPV+435/2008>. Citado na página 105.

CORREA, A. d. S.; MINELLA, A. Nonlinear Mechanisms of the Exchange Rate Pass-Through: A Phillips curve model with threshold for Brazil. Revista Brasileira de Economia, v. 64, n. 3, p. 231-243, set. 2010. ISSN 0034-7140. Disponível em: <http://www.scielo.br/pdf/rbe/v64n3/a01v64n3.pdf>. Citado na página 40.

DELLASOPPA, E. E. Corruption in Brazil. In: Policing Corruption: International Perspectives. [S.1.]: Lexington Books, 2004. p. 37-49. ISBN 9780739108093. Citado na página 105.

DEVEREUX, M. B.; SHI, K.; XU, J. Oil Currency and the Dollar Standard: A Simple Analytical Model of an International Trade Currency. Journal of Money, Credit and Banking, v. 42, n. 4, p. 521-550, 2010. ISSN 1538-4616. Citado na página 62.

DIXIT, A. K.; STIGLITZ, J. E. Monopolistic Competition and Optimum Product Diversity. The American Economic Review, v. 67, n. 3, p. 297-308, jun. 1977. ISSN 0002-8282. Disponível em: < http://www.jstor.org/stable/1831401>. Citado na página 94.

DUTU, R.; NOSAL, E.; ROCHETEAU, G. On the recognizability of money. [S.l.], 2005. Disponível em: <https://ideas.repec.org/p/fip/fedcwp/0512.html>. Citado na página 25.

EICHENGREEN, B.; FLANDREAU, M. The Federal Reserve, the Bank of England, and the Rise of the Dollar as an International Currency, 1914-1939. Open Econ Rev, v. 23, n. 1, p. 57-87, fev. 2012. Citado 2 vezes nas páginas 16 e 23.

EICHENGREEN, B. J. Does Mercosur Need a Single Currency. Cambridge, 1998. Disponível em: <http://www.nber.org/papers/w16231.pdf>. Citado na página 18.

EICHENGREEN, B. J. The Eurozone Crisis: The Theory of Optimum Currency Areas Bites Back. [S.l.], 2014. Disponível em: <https://www.notenstein.ch/sites/default/files/ publications/white \_paper \_eichengreen.pdf $>$. Citado na página 35.

EICHENGREEN, B. J.; HAUSMANN, R.; PANIZZA, U. The Pain of Original Sin. In: Other people's money : debt denomination and financial instability in emerging market economies. Chicago: University of Chicago Press, 2005. p. 13-37. ISBN 978-02-26194-55-4. Citado na página 40.

EICHENGREEN, B. J.; KAWAI, M. Issues for Renminbi Internationalization: An Overview. [S.l.], 2014. 22 p. Disponível em: <http://www.adbi.org/working-paper/>. Citado na página 24.

ENGEL, C.; ROGERS, J. H. Deviations from purchasing power parity: causes and welfare costs. Journal of International Economics, v. 55, n. 1, p. 29-57, out. 2001. ISSN 0022-1996. Citado na página 40. 
ENGLE, R.; ISSLER, J. V. Common trends and common cycles in Latin America. Revista Brasileira de Economia, v. 47, n. 2, p. 149-76, 1993. Citado na página 18.

ETHIER, W. International Trade and the Forward Exchange Market. The American Economic Review, v. 63, n. 3, p. 494-503, jun. 1973. ISSN 00028282. Citado na página 110.

European Comission. Council Regulation (EC) N 974/98. 1998. Citado na página 77.

FEENSTRA, R. C. International Economics. Second edition edition. New York, NY: Worth Publishers, 2011. ISBN 9781429231183. Citado na página 32.

FERRARI-FILHO, F. et al. Uma avaliação crítica da proposta de conversibilidade plena do real. Revista de Política Internacional, v. 25, n. 1, p. 133-151, 2005. Disponível em: $<$ http://econpapers.repec.org/paper/cdptexdis/td235.htm>. Citado na página 18.

FILHO, F. F.; PAULA, L. F. de. Será Consistente a Proposta de Criação de uma União Monetária no Mercosul? Revista de Economia Política, v. 22, n. 2, p. 174-182, 2002. Disponível em: <http://www.rep.org.br/pdf/86-10.pdf>. Citado na página 18.

FISCHER, S. Seigniorage and the Case for a National Money. Journal of Political Economy, v. 90, n. 2, p. 295-313, abr. 1982. ISSN 0022-3808. Disponível em: $<$ http://www.jstor.org/stable/1830294>. Citado na página 33.

FLANDREAU, M.; JOBST, C. The empirics of international currencies: Network externalities, history and persistence. Economic Journal, v. 119, n. 537, p. 643-664, 2009. Citado 2 vezes nas páginas 23 e 44.

FRANKEL, J. A. Internationalization of the RMB and Historical Precedents. Journal of Economic Integration, v. 27, p. 329-365, 2012. Citado 7 vezes nas páginas 16, 23, 26, 29, 43, 71 e 95 .

FRIBERG, R.; WILANDER, F. The currency denomination of exports - a questionnaire study. Journal of International Economics, v. 75, n. 1, p. 54-69, 2008. Citado 3 vezes nas páginas 42, 43 e 65 .

GENBERG, H. Currency Internationalization: Analytical and Policy Issues. In: Currency internationalisation: lessons from the global financial crisis and prospects for the future in Asia and the Pacific. Bank for International Settlements, 2011. v. 61, p. 221-230. 31.

Disponível em: <http://www.bis.org/publ/bppdf/bispap61q.pdf>. Citado na página 15.

GERRING, J. What Makes a Concept Good? A Criterial Framework for Understanding Concept Formation in the Social Sciences. Polity, v. 31, n. 3, p. 357-393, 1999. Disponível em: < http://www.jstor.org/stable/3235246>. Citado na página 24.

GIAMBIAGI, F. Uma proposta de unificação monetária dos países do Mercosul. Revista de Economia Política, v. 17, n. 4, p. 5-30, 1997. ISSN 0101-3157. Disponível em: $<$ http://www.rep.org.br/PDF/68-1.PDF>. Citado na página 18.

GIAMBIAGI, F. Moeda única do Mercosul: notas para o debate. Revista Brasileira de Política Internacional, v. 41, p. 24-39, 1998. ISSN 0034-7329. 1. Disponível em: $<$ http://www.scielo.br/scielo.php?script=sci_arttext\&pid=S0034-73291998000100002\& nrm $=$ iso $>$. Citado na página 18. 
GIAMBIAGI, F.; BARENBOIM, I. A Unificação Monetária Alemã: Lições para uma Possivel Moeda Comum entre Brasil e Argentina. Rio de Janeiro, 2002. 15. Citado na página 18.

GNOS, C.; MONVOISIN, V.; PONSOT, J.-F. Regional currencies and regional monetary zones in Latin America: what prospects? Journal of Post Keynesian Economics, v. 32, n. 2, p. 173-184, dez. 2009. ISSN 0160-3477. Disponível em: <http://mesharpe.metapress. com/openurl.asp?genre $=$ article\&id $=$ doi:10.2753/PKE0160-3477320203 $>$. Citado na página 18.

GOLDBERG, D. Legal Tender. [S.1.], 2009. Disponível em: <http://econpapers.repec.org/ paper/biuwpaper/2009-4.htm>. Citado na página 76.

GOLDBERG, L. S.; TILLE, C. Vehicle currency use in international trade. Journal of International Economics, v. 76, n. 2, p. 177-192, dez. 2008. ISSN 0022-1996. Citado 2 vezes nas páginas 43 e 62 .

GOLDBERG, L. S.; TILLE, C. A Bargaining Theory of Trade Invoicing and Pricing. [S.l.], 2013. Disponível em: <http://www.nber.org/papers/w18985>. Citado 4 vezes nas páginas 42, 62, 97 e 98.

GONÇALVES, F. M.; HOLLAND, M.; SPACOV, A. D. Can Jurisdictional Uncertainty and Capital Controls Explain the High Level of Real Interest Rates in Brazil? Evidence from Panel Data. Revista Brasileira de Economia, v. 61, n. 1, p. 49-75, 2007. Citado na página 19.

GRAUWE, P. D. German monetary unification. European Economic Review, v. 36, n. 2-3, p. 445-453, abr. 1992. ISSN 0014-2921. Citado na página 35.

HAHN, H. J. The European Central Bank: Key to European Monetary Union or Target. Common Market Law Review, v. 28, n. 4, p. 783-820, dez. 1991. ISSN 0165-0750.

Disponível em: <http://www.kluwerlawonline.com/abstract.php?area=Journals\&id= COLA1991044>. Citado na página 36.

HAUSMANN, R.; PANIZZA, U. Redemption or Abstinence? Original Sin, Currency Mismatches and Counter Cyclical Policies in the New Millennium. Journal of Globalization and Development, v. 2, n. 1, 2011. Citado na página 40.

HELLEINER, E. National Currencies and National Identities. American Behavioral Scientist, v. 41, n. 10, p. 1409-1436, ago. 1998. ISSN 0002-7642, 1552-3381. Citado na página 30.

HELLEINER, E. The Status Quo Crisis: Global Financial Governance After the 200\%-08 Financial Meltdown. [S.l.]: Oxford University Press, 2014. ISBN 9780199973637. Citado na página 72 .

INSTEFJORD, N. Risk and hedging: Do credit derivatives increase bank risk? Journal of Banking ES Finance, v. 29, n. 2, p. 333-345, fev. 2005. ISSN 0378-4266. Citado na página 101.

International Monetary Fund. AREAER Online. 2015. Disponível em: <www. elibrary-areaer.imf.org $>$. Citado 3 vezes nas páginas 77, 81 e 82. 
ISHIYAMA, Y. The Theory of Optimum Currency Areas: A Survey. IMF Staff Papers, v. 22, n. 2, p. 344-383, 1975. ISSN 1020-7635. Disponível em: <http://www.jstor.org/stable/3866482>. Citado 2 vezes nas páginas 34 e 74 .

ITO, T. et al. The Choice of an Invoicing Currency by Globally Operating Firms: a Firm-Level Analysis of Japanese Exporters. International Journal of Finance Ef Economics, v. 17, n. 4, p. 305-320, 2012. ISSN 1099-1158. Disponível em: <http://dx.doi.org/10.1002/ijfe.1450>. Citado 2 vezes nas páginas 42 e 97.

ITO, T. et al. Exchange Rate Risk Management of Export Firms: New findings from a questionnaire survey. [S.1.], 2013. Citado 3 vezes nas páginas 42, 43 e 65.

JEVONS, W. S. Money and the Mechanism of Exchange. New York: D. Appleton and Co., 1875. Citado 2 vezes nas páginas 86 e 110.

KAFKA, A. Optimum Currency Areas and Latin Amercia. In: The Economics of Common Currencies. Great Britain: Allen \& Unwin, 1973. p. 210-218. Citado na página 18.

KANNAN, P. On the welfare benefits of an international currency. European Economic Review, v. 53, n. 5, p. 588-606, jul. 2009. ISSN 0014-2921. Disponível em: $<$ http://www.sciencedirect.com/science/article/pii/S0014292108001013>. Citado 2 vezes nas páginas 17 e 23.

KAWAI, M.; ZILCHA, I. International trade with forward-futures markets under exchange rate and price uncertainty. Journal of International Economics, v. 20, n. 1-2, p. 83-98, fev. 1986. ISSN 0022-1996. Disponível em: <http: //www.sciencedirect.com/science/article/pii/0022199686900620>. Citado na página 110.

KENEN, P. B. The Theory of Optimum Currency Areas: An Eclectic View. In: MUNDELL, R. A.; SWOBODA, A. K. (Ed.). Monetary Problems in the International Economy. Chicago: University of Chicago Press, 1969. p. 41-60. Citado 2 vezes nas páginas 34 e 74 .

KENEN, P. B. The International Economy. 4 edition. ed. Cambridge England ; New York: Cambridge University Press, 2000. ISBN 9780521644358. Citado na página 32.

KENEN, P. B. Currency internationalisation: an overview. In: Currency internationalisation: lessons from the global financial crisis and prospects for the future in Asia and the Pacific. Bank for International Settlements, 2011, ( Papers, 61). p. 9-18. Disponível em: <http://www.bis.org/publ/bppdf/bispap61d.pdf>. Citado 3 vezes nas páginas 23, 26 e 42 .

KIRSHNER, J. Currency and coercion: the political economy of international monetary power. New Jersey: Princeton University Press, 1995. Citado 2 vezes nas páginas 40 e 71.

KIRSHNER, J. Currency and Coercion in the Twenty-First Century. In: International Monetary Power. New York: Cornell University Press, 2006. p. 139-161. Citado na página 17.

KIYOTAKI, N.; WRIGHT, R. On Money as a Medium of Exchange. The Journal of Political Economy, v. 97, n. 4, p. 927-954, ago. 1989. Disponível em: $<$ http://www.jstor.org/stable/1832197>. Citado na página 86. 
KIYOTAKI, N.; WRIGHT, R. A Search-Theoretic Approach to Monetary Economics. The American Economic Review, v. 83, n. 1, p. 63-77, mar. 1993. ISSN 0002-8282. Disponível em: <http://www.jstor.org/stable/2117496>. Citado 2 vezes nas páginas 86 e 88 .

KOCHERLAKOTA, N. R.; KRUEGER, T. Why Do Different Countries Use Different Currencies? [S.l.], 1998. Disponível em: <http://www.imf.org/external/pubs/ft/wp/ wp9817.pdf $>$. Citado na página 74.

KRUGMAN, P. Scale Economies, Product Differentiation, and the Pattern of Trade. The American Economic Review, v. 70, n. 5, p. 950-959, 1980. ISSN 0002-8282. Disponível em: <http://www.jstor.org/stable/1805774>. Citado na página 94.

KRUGMAN, P. Vehicle currencies and the structure of international exchange. Journal of Money, Credit and Banking, v. 12, n. 3, p. 513-526, 1980. ISSN 00222879. Disponível em: <http://www.jstor.org/stable/1991725>. Citado 3 vezes nas páginas 42, 43 e 62.

KRUGMAN, P. Revenge of the optimum currency area. NBER Macroeconomics Annual, v. 27, n. 1, p. 439-448, jan. 2013. ISSN 08893365. Citado na página 35.

KRUGMAN, P. R.; OBSTFELD, M.; MELITZ, M. J. International economics: theory $\&$ policy. Boston: Pearson Addison-Wesley, 2012. ISBN 9780132146654 0132146657. Citado na página 32.

Law Library of Congress. Regulation of Bitcoin in Selected Jurisdictions. [S.l.], 2014. Disponível em: < http://www.loc.gov/law/help/bitcoin-survey/regulation-of-bitcoin.pdf > . Citado na página 75 .

LEESON, P. T. How important is state enforcement for trade? Am Law Econ Rev, v. 10, n. 1, p. 61-89, mar. 2008. Citado na página 31.

LERNER, A. P. The Economics of Control: Principles of Welfare Economics. New York: Macmillan, 1944. Citado na página 34.

LESTER, B.; POSTLEWAITE, A.; WRIGHT, R. Information, Liquidity, Asset Prices, and Monetary Policy. The Review of Economic Studies, v. 79, n. 3, p. 1209-1238, jul. 2012. ISSN 0034-6527, 1467-937X. Disponível em: $<$ http://restud.oxfordjournals.org/content/79/3/1209>. Citado na página 25.

MALZ, A. M. Option-implied probability distributions and currency excess returns. [S.l.], 1997. Disponível em: < https://ideas.repec.org/p/fip/fednsr/32.html>. Citado na página 84.

MARESCAUX, J. et al. Transcontinental Robot-Assisted Remote Telesurgery: Feasibility and Potential Applications. Annals of Surgery, v. 235, n. 4, p. 487-492, abr. 2002. ISSN 0003-4932. Disponível em: <http://www.ncbi.nlm.nih.gov/pmc/articles/PMC1422462/>. Citado na página 93.

MATIAS-PEREIRA, J. The Effects of the Recovery of the Patrimonialist Model in Brazil. International Journal of Humanities and Social Science, v. 3, n. 8, abr. 2013. ISSN 2221-0989. Disponível em: <http://www.ijhssnet.com/journals/Vol_3_No_8_Special_ Issue_April_2013/3.pdf $>$. Citado na página 105. 
MATSUYAMA, K.; KIYOTAKI, N.; MATSUI, A. Toward a Theory of International Currency. The Review of Economic Studies, v. 60, n. 2, p. 283-307, 1993. ISSN 00346527. 2. Disponível em: <http://www.jstor.org/stable/2298058>. Citado na página 88.

MCBRIDE, N. Payments and the concept of legal tender. Reserve Bank of New Zealand Bulletin, v. 70, 2007. Disponível em: <http://www.rbnz.govt.nz/research_and_ publications/reserve_bank_bulletin/2007/2007sep70_3mcbride.pdf $>$. Citado na página 76 .

MCKINNON, R. I. Optimum Currency Areas. The American Economic Review, v. 53, p. 717-725, 1963. ISSN 00028282. 4. Disponível em: <http://www.jstor.org/stable/1811021>. Citado 3 vezes nas páginas 17, 34 e 74 .

MCKINNON, R. I. Money in International Exchange: The Convertible Currency System. New York: Oxford University Press, 1979. ISBN 0195024095. Citado 3 vezes nas páginas 42,43 e 62 .

MENGER, K. On the Origin of Money. The Economic Journal, v. 2, n. 6, p. 239-255, jun. 1892. ISSN 0013-0133. Citado na página 31.

MERCOSUL. Decisão n. 25/200\%. 2007. Disponível em: <http://gd.mercosur.int/SAM\% 5CGestDoc\%5Cpubweb.nsf/E3FD2A12509D6E08032579A20065CEE5/\$File/DEC 025-2007_PT_FERR_Transa\%E2\%80\%A1oesComerciaisMoedas\%20Locais.pdf $>$. Citado na página 103.

Ministério do Desenvolvimento, Indústria e Comércio Exterior. Metodologia de produção de estatísticas de comércio exterior. 2013. Disponível em: <http: $/ /$ www.mdic.gov.br/sitio/interna/interna.php?area $=5 \& m e n u=605 \&$ refr $=2350>$. Citado na página 45.

MOSS, F. The euro: internationalised at birth. In: Currency internationalisation: lessons from the global financial crisis and prospects for the future in Asia and the Pacific. Bank for International Settlements, 2011, ( Papers, 61). p. 57-74. Disponível em: <http://www.bis.org/publ/bppdf/bispap61f.pdf>. Citado 2 vezes nas páginas 24 e 35.

MUNDELL, R. A. A Theory of Optimum Currency Areas. The American Economic Review, v. 51, p. 657-665, 1961. ISSN 00028282. 4. Disponível em: <http://www.jstor.org/stable/1812792>. Citado 4 vezes nas páginas 17, 34, 36 e 74.

MUNIZ, P. M. C. Criação e Evolução do Segmento de Câmbio de Taxas Flutuantes: considerações sobre o fluxo cambial, unificação e plano real. Tese (Dissertação de Mestrado) - Universidade Federal do Cerá, Fortaleza, 1999. Citado na página 105.

NOGUEIRA, V. d. A.; MORI, R.; MARÇAL, E. F. Transmissão da variação cambial para as taxas de inflação no Brasil: estimação do pass-through através de modelos de vetores autorregressivos estruturais com correção de erros. [S.1.], 2013. Disponível em: $<$ https://ideas.repec.org/p/fgv/eesptd/349.html>. Citado na página 40.

OBSTFELD, M.; ROGOFF, K. Exchange Rate Dynamics Redux. Journal of Political Economy, v. 103, n. 3, p. 624-660, jun. 1995. ISSN 0022-3808. Disponível em: $<$ http://www.jstor.org/stable/2138701>. Citado na página 40. 
OBSTFELD, M.; ROGOFF, K. The Six Major Puzzles in International Macroeconomics: Is There a Common Cause? [S.1.], 2000. Disponível em: <http://www.nber.org/papers/ w7777>. Citado na página 74.

OREIRO, J. L. d. C.; PAUlA, L. F. de; SILVA, G. J. C. da. Por uma Moeda Parcialmente Conversivel. Revista de Economia Política, v. 24, n. 2, p. 223-227, 2004. Citado na página 18.

OSTROY, J. M.; STARR, R. M. The transactions role of money. In: Benjamin M. Friedman and Frank H. Hahn (Ed.). Handbook of Monetary Economics. Elsevier, 1990. Volume 1, p. 3-62. ISBN 1573-4498. Disponível em: <http: //www.sciencedirect.com/science/article/pii/S1573449805800049>. Citado na página 29.

PADOA-SCHIOPPA, T. EMU and Banking Supervision. International Finance, v. 2, n. 2, p. 295-308, jul. 1999. ISSN 1468-2362. Citado na página 36.

PAPAIOANNOU, E.; PORTES, R. Costs and benefits of running an international currency. Brussels, 2008. 348. Citado 5 vezes nas páginas 16, 17, 43, 71 e 95.

PUGEL, T. International Economics. 15 edition. ed. New York: McGraw-Hill/Irwin, 2011. ISBN 9780073523170. Citado na página 32.

REISS, D. G. Reduzindo Custos de Comércio no Mercosul [Easing Trade Costs within Mercosul]. Revista Tempo do Mundo, v. 5, n. 1, p. 137-151, abr. 2013. ISSN 2176-7025. Disponível em: <http://www.ipea.gov.br/portal/images/stories/PDFs/rtm/140903 rtmv5_n1_port_cap5.pdf $>$. Citado 2 vezes nas páginas 102 e 105.

REISS, D. G. Invoice currency: Puzzling evidence and new questions from Brazil. EconomiA, v. 16, n. 2, p. 206-225, maio 2015. ISSN 1517-7580. Disponível em: <http://www.sciencedirect.com/science/article/pii/S151775801500017X>. Citado na página 116.

ROBINSON, J. The Economics of Imperfect Competition. London: Macmillan, 1933. Citado na página 94.

SALVATORE, D. International Economics. 10th. ed. New Jersey: Wiley, 2009. ISBN 978-0470388341. Citado na página 32.

SANDMO, A. On the Theory of the Competitive Firm Under Price Uncertainty. The American Economic Review, v. 61, n. 1, p. 65-73, mar. 1971. ISSN 00028282. Citado 3 vezes nas páginas 111, 112 e 114.

SMITH, A. An Inquiry into the Nature and Causes of the Wealth of Nations. London: W. Strahan and T. Cadell, 1776. Citado 2 vezes nas páginas 29 e 75.

SONO, K. Legal Tender: a Notion associated with Payment. In: Current Developments in Monetary and Financial Law. New York: International Monetary Fund, 2003. p. 679-687. ISBN 9781589061767. Citado na página 30.

SOUDEK, J. Aristotle's Theory of Exchange: An Inquiry into the Origin of Economic Analysis. Proceedings of the American Philosophical Society, v. 96, n. 1, p. 45-75, fev. 1952. ISSN 0003049X. Citado na página 29. 
SOUZA, C. d. et al. Contabilidade: teoria e prática. 6. ed. São Paulo: Atlas, 2011. v. 1. ISBN 9788522461080. Citado na página 83.

STEIL, B.; HINDS, M. Money, Markets, and Sovereignty. Kindle version. New Haven: Yale University Press, 2009. ISBN 9780300149241. Citado na página 30.

SWOBODA, A. K. The Euro-dollar market: an interpretation. Princeton University: International Finance Section, Dept. of Economics, Princeton University, 1968. (Essays in International Finance, 64). Citado 3 vezes nas páginas 43, 71 e 95.

SWOBODA, A. K. Vehicle currencies and the foreign exchange market: the case of the dollar. In: ALIBER, R. Z. (Ed.). The International Market for Foreign Exchange. New York: Frederick A. Praeger, Publishers, 1969, (Praeger Special Studies in International Economics and Development). p. 30-40. Citado na página 43.

TAVLAS, G. S. The 'New' Theory of Optimum Currency Areas. World Economy, v. 16, n. 6, p. 663-685, nov. 1993. ISSN 1467-. Citado na página 35.

TEIXEIRA, P. G.; SCHINASI, G. J. The Lender of Last Resort in the European Single Financial Market. [S.l.], 2006. Disponível em: < http://www.imf.org/external/pubs/ft/wp/ 2006/wp06127.pdf>. Citado na página 36.

TRUCCO, P. The Rise of Monetary Agreements in South America. In: RIGGIROZZI, P.; TUSSIE, D. (Ed.). The Rise of Post-Hegemonic Regionalism. [S.l.]: Springer Netherlands, 2012, (United Nations University Series on Regionalism, 4). p. 101-124. ISBN 978-94-007-2693-2, 978-94-007-2694-9. Citado na página 102.

TUFANO, P. Chapter 6 Financial innovation. In: CONSTANTINIDES, M. H. a. R. S. G. (Ed.). Handbook of the Economics of Finance. [S.l.]: Elsevier, 2003. v. 1, Part A, p. 307-335. ISBN 1574-0102. Citado na página 101.

VIAENE, J.-M.; VRIES, C. G. de. International trade and exchange rate volatility. European Economic Review, v. 36, n. 6, p. 1311-1321, ago. 1992. ISSN 0014-2921. Citado na página 111.

VIAENE, J.-M.; ZILCHA, I. The Behavior of Competitive Exporting Firms under Multiple Uncertainty. International Economic Review, v. 39, n. 3, p. 591-609, ago. 1998. ISSN 0020-6598. Disponível em: <http://www.jstor.org/stable/2527391>. Citado na página 111.

VOLZ, U. RMB internationalisation and currency co-operation in East Asia. [S.l.], 2013. Disponível em: <http://ideas.repec.org/p/zbw/leiwps/125.html>. Citado na página 17.

WARE, R.; WINTER, R. Forward markets, currency options and the hedging of foreign exchange risk. Journal of International Economics, v. 25, n. 3-4, p. 291-302, nov. 1988. ISSN 0022-1996. Disponível em: < http://www.sciencedirect.com/science/article/pii/ 0022199688900566>. Citado na página 110.

WEBER, E. J. A Short History of Derivative Security Markets. In: HAFNER, W.; ZIMMERMANN, H. (Ed.). Vinzenz Bronzin's Option Pricing Models: Exposition and Appraisal. Basel: Springer-Verlag Berlin Heidelberg, 2009. p. 431-466. ISBN 978-35-408571-05. Disponível em: <http://dx.doi.org/10.1007/978-3-540-85711-2_21>. Citado na página 101. 
WILLIAMSON, S.; WRIGHT, R. New Monetarist Economics: Models. In: Benjamin M. Friedman and Michael Woodford (Ed.). Handbook of Monetary Economics. Elsevier, 2010. Volume 3, p. 25-96. ISBN 1573-4498. Disponível em: $<$ http://www.sciencedirect.com/science/article/pii/B9780444532381000028>. Citado na página 25.

WONG, K. P. International trade and hedging under joint price and exchange rate uncertainty. International Review of Economics \& Finance, v. 27, p. 160-170, 2013. ISSN 1059-0560. Disponível em: <http://www.sciencedirect.com/science/article/pii/ S1059056012001165>. Citado na página 111.

WU, F.; PAN, R.; WANG, D. Renminbi's potential to become a global currency. China \& World Economy, v. 18, p. 63-81, 2010. ISSN 1749-124X. 1. Citado na página 44.

ZARUTSKIE, R. Competition, financial innovation and commercial bank loan portfolios. Journal of Financial Intermediation, v. 22, n. 3, p. 373-396, jul. 2013. ISSN 1042-9573. Citado na página 101.

ZHANG, C. An information-based theory of international currency. Journal of International Economics, v. 93, n. 2, p. 286-301, jul. 2014. ISSN 0022-1996. Citado 2 vezes nas páginas 42 e 65 . 